September 2004 - NREL/SR-500-36416

\title{
Avian Monitoring and Risk Assessment at the Tehachapi Pass Wind Resource Area
}

\author{
Period of Performance: \\ October 2, 1996 - May 27, 1998
}

R. Anderson, N. Neumann, and J. Tom State Energy Resources Conservation and Development Commission Sacramento, California W.P. Erickson, M.D. Strickland, M. Bourassa, K.J. Bay, and K.J. Sernka Western EcoSystems Technology, Inc. Cheyenne, Wyoming

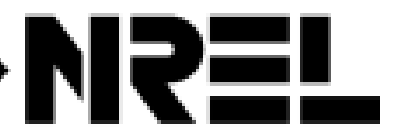

National Renewable Energy Laboratory 1617 Cole Boulevard, Golden, Colorado 80401-3393 303-275-3000 • www.nrel.gov

Operated for the U.S. Department of Energy Office of Energy Efficiency and Renewable Energy by Midwest Research Institute • Battelle 
September 2004 - NREL/SR-500-36416

\section{Avian Monitoring and Risk Assessment at the Tehachapi Pass Wind Resource Area}

Period of Performance: October 2, 1996 - May 27, 1998

R. Anderson, N. Neumann, and J. Tom State Energy Resources Conservation and Development Commission Sacramento, California

W.P. Erickson, M.D. Strickland, M. Bourassa, K.J. Bay, and K.J. Sernka Western EcoSystems Technology, Inc. Cheyenne, Wyoming

NREL Technical Monitor: K. Sinclair

Prepared under Subcontract No. ZAT-6-15179-02, TAM-7-16454-01 ,

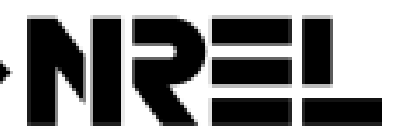

National Renewable Energy Laboratory

1617 Cole Boulevard, Golden, Colorado 80401-3393

303-275-3000 • www.nrel.gov

Operated for the U.S. Department of Energy

Office of Energy Efficiency and Renewable Energy

by Midwest Research Institute • Battelle

Contract No. DE-AC36-99-G010337 


\section{NOTICE}

This report was prepared as an account of work sponsored by an agency of the United States government. Neither the United States government nor any agency thereof, nor any of their employees, makes any warranty, express or implied, or assumes any legal liability or responsibility for the accuracy, completeness, or usefulness of any information, apparatus, product, or process disclosed, or represents that its use would not infringe privately owned rights. Reference herein to any specific commercial product, process, or service by trade name, trademark, manufacturer, or otherwise does not necessarily constitute or imply its endorsement, recommendation, or favoring by the United States government or any agency thereof. The views and opinions of authors expressed herein do not necessarily state or reflect those of the United States government or any agency thereof.

Available electronically at http://www.osti.gov/bridge

Available for a processing fee to U.S. Department of Energy and its contractors, in paper, from:

U.S. Department of Energy

Office of Scientific and Technical Information

P.O. Box 62

Oak Ridge, TN 37831-0062

phone: 865.576.8401

fax: 865.576.5728

email: mailto:reports@adonis.osti.gov

Available for sale to the public, in paper, from:

U.S. Department of Commerce

National Technical Information Service

5285 Port Royal Road

Springfield, VA 22161

phone: 800.553 .6847

fax: 703.605.6900

email: orders@ntis.fedworld.gov

online ordering: http://www.ntis.gov/ordering.htm 


\section{Table of Contents}

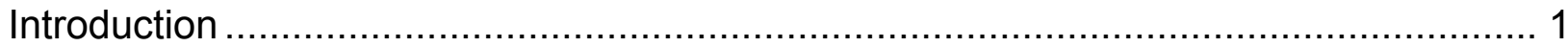

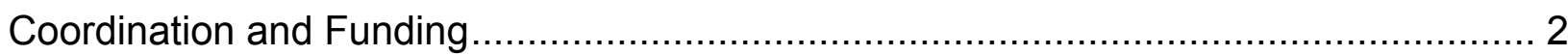

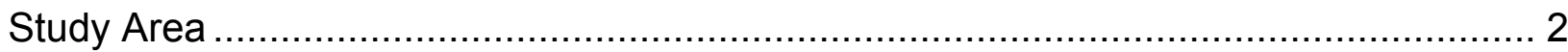

Study Objectives and Key Research Questions ............................................... 3

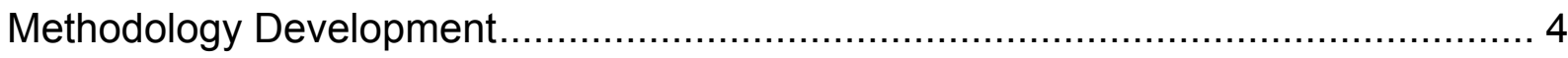

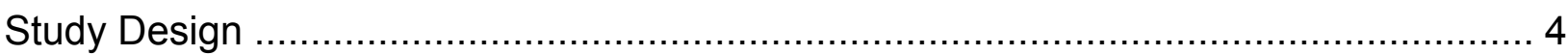

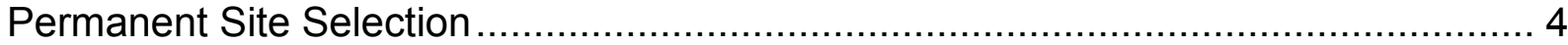

Observer Detection Efficiency Study Site Selection ........................................... 6

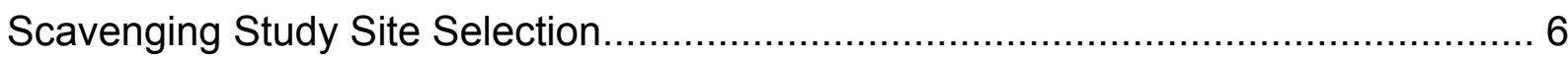

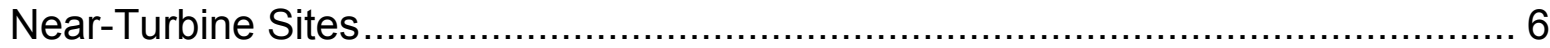

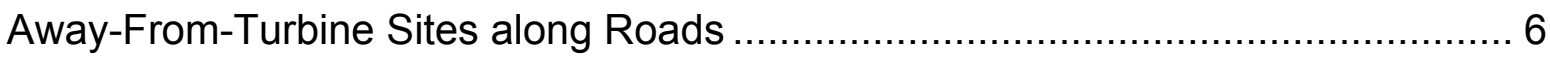

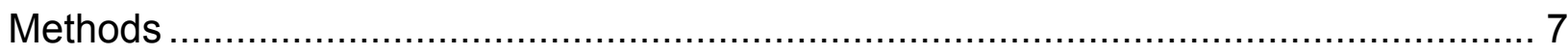

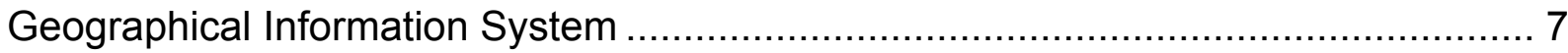

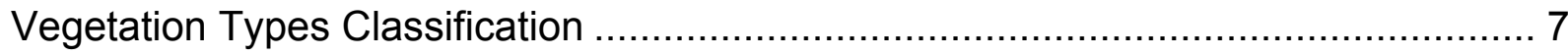

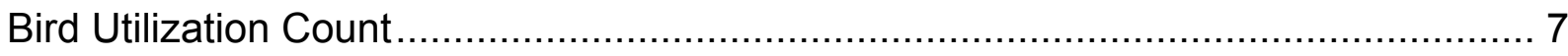

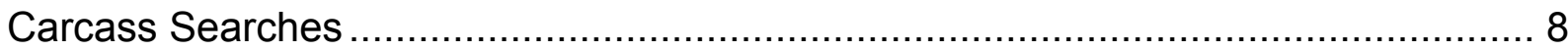

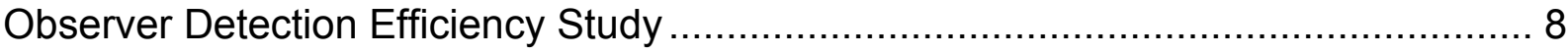

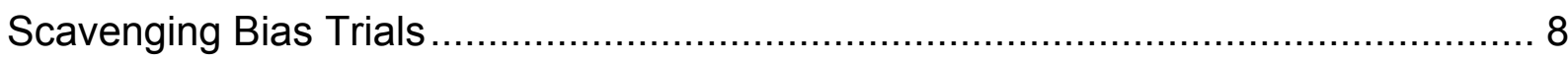

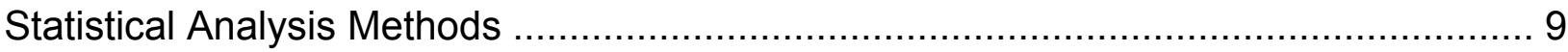

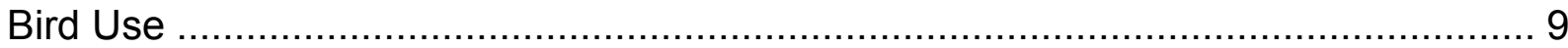

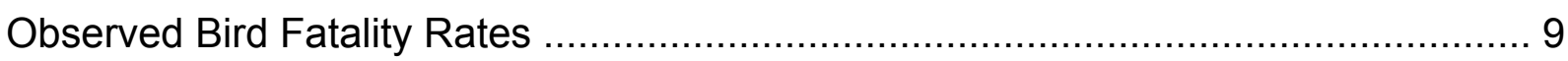

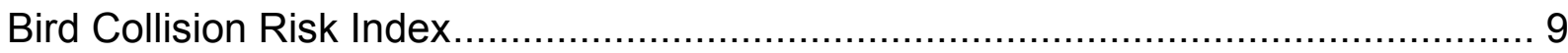

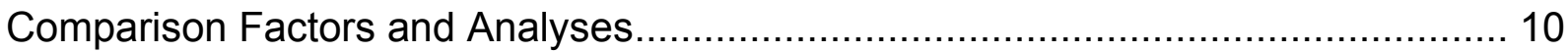

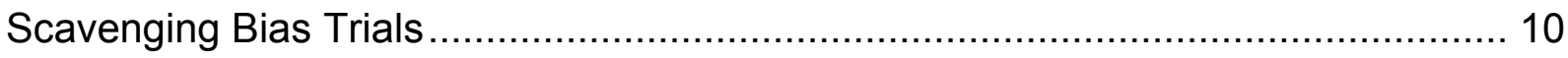

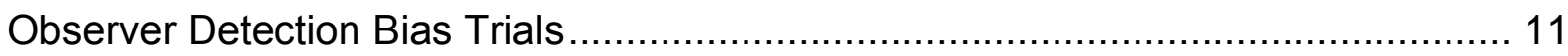

Quality Assurance and Quality Control ............................................................ 11

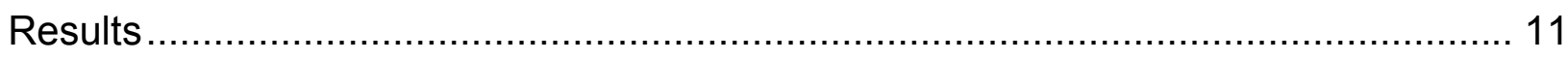

General Avian Use, Frequency Occurrence and Species Composition ................... 11

Avian Use by Bird Group .......................................................................... 12 


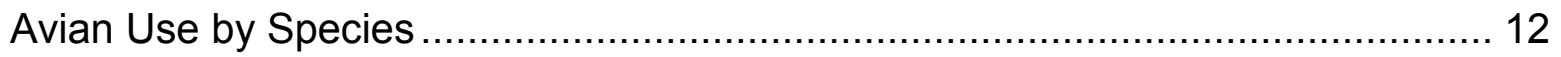

Avian Flight Height Characteristics ........................................................... 13

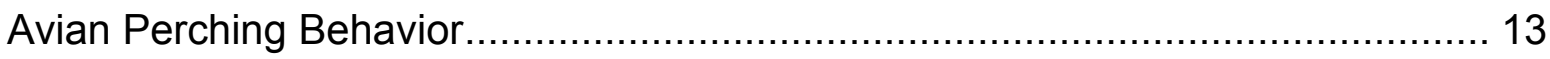

Avian Fatality Counts and Composition............................................................ 13

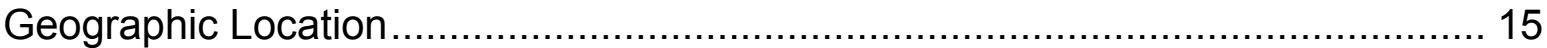

Standardized Bird Utilization, Fatality Rates and Risk Index Comparisons ............... 15

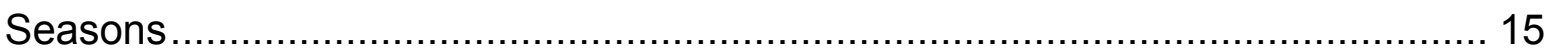

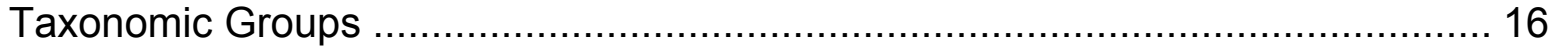

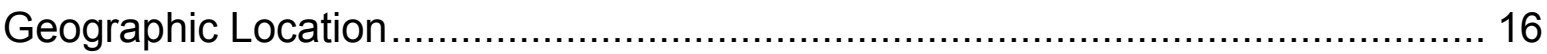

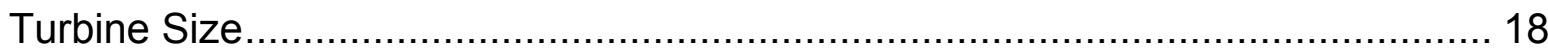

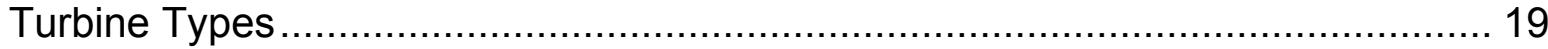

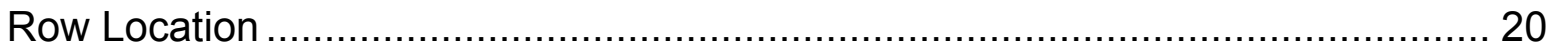

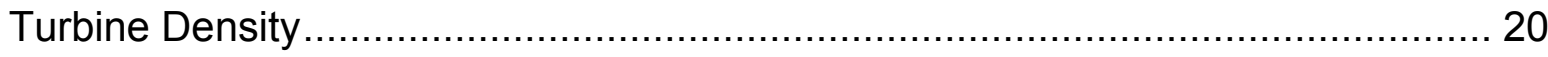

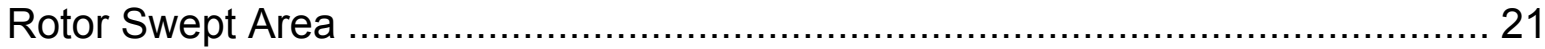

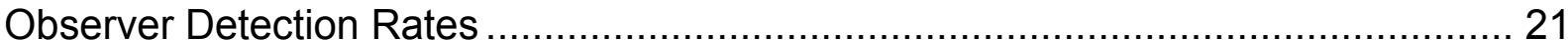

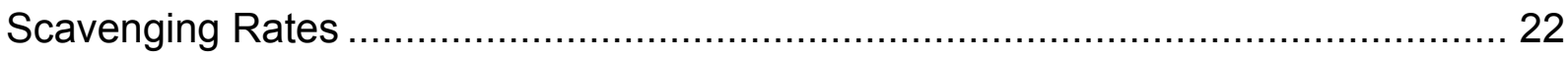

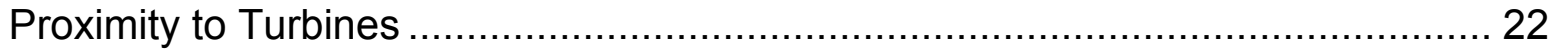

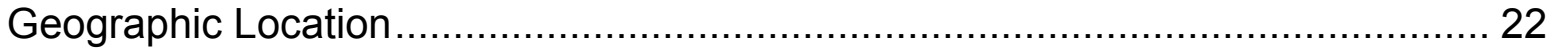

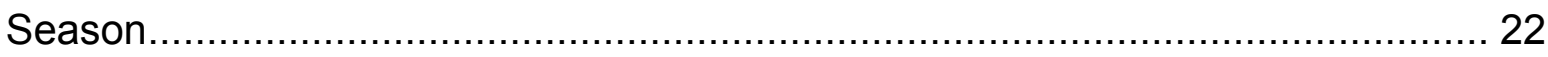

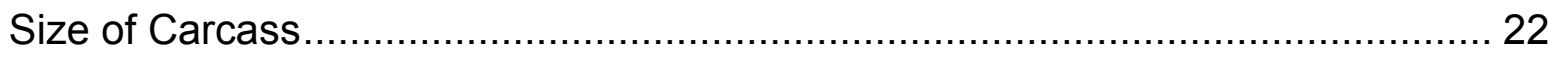

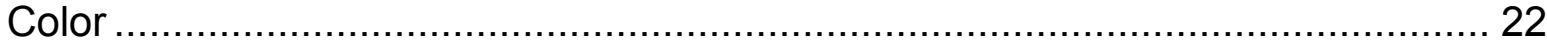

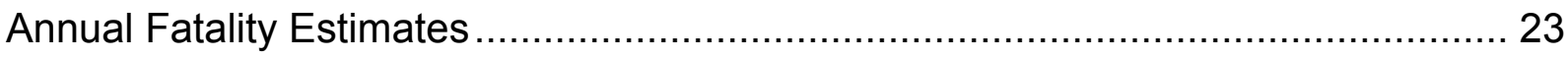

Discussion, Conclusions, and Recommendations ................................................ 23

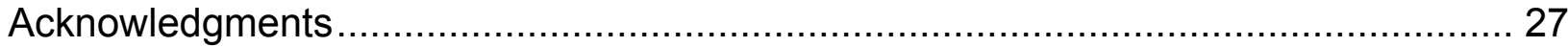

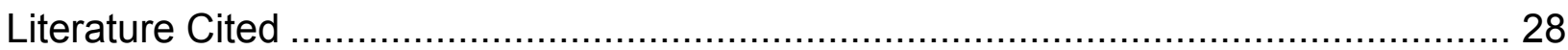

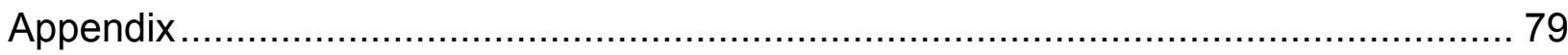




\section{List of Tables}

Table 1. Vegetation Types Documented during Phase I Studies at Tehachapi Pass Wind Resource Area, 2 October 1996 to 27 May 1998 (Based on Vegetation Observed

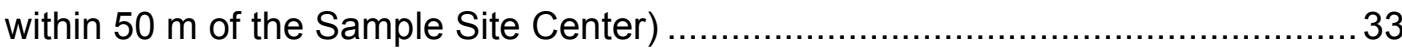

Table 2. Description of Turbines within the Tehachapi Pass WRA and the Turbines Selected to Be Studied (Approximately $95 \%$ of the Turbines within the WRA were Documented)

Table 3. Sample Sizes for Each Factor Used in Comparison of Fatality Rates, Use, and Collision Risk

Table 4. Number of Groups and Individuals of Avian Groups Observed during Bird Utilization Surveys at Tehachapi Pass Wind Resource Area, 2 October 1996 to 27 May 1998

Table 5. Avian Abundance and Richness by Season during Phase I Utilization Surveys at Tehachapi Pass Wind Resource Area, 2 October 1996 to 27 May 1998.

(Calculated Based on Observations within $200 \mathrm{~m}$ of Site Center)....

Table 6. Mean Abundance, Percent Composition, and Percent Frequency of Occurrence of Avian Groups Observed during Phase I Utilization Surveys at Tehachapi Pass Wind Resource Area, 2 October 1996 to 27 May 1998 (Calculated Based on Observations within $200 \mathrm{~m}$ of Site Center)

Table 7. Five Most Abundant Avian Species (Based on Mean Number per Five Minute Utilization Survey) Observed during Phase I Utilization Surveys at Tehachapi Pass Wind Resource Area, 2 October 1996 to 27 May 1998 (Calculated Based on Observations within 200 m of Site Center) 40

Table 8. Five Most Frequently Occurring Avian Species during Phase I Utilization Surveys at Tehachapi Pass Wind Resource Area, 2 October 1996 to 27 May 1998 (Calculated Based on Observations within 200 m of Site Center)

Table 9. Flight Height Characteristics by Avian Group Observed during Phase I Utilization Surveys at Tehachapi Pass Wind Resource Area, 2 October 1996 to 27 May 1998

Table 10. Characteristics of Perching Locations 45

Table 11. Number of avian Fatalities Observed during This Study at Tehachapi Pass Wind Resource Area, 2 October 1996 to 27 May 1998. 
Table 12. Composition of Avian Fatalities Observed during Phase I Study Period at Tehachapi Pass Wind Resource Area, 2 October 1996 to 27 May 1998

Table 13. Mean Use Observed during Phase I Utilization Surveys at Tehachapi Pass Wind Resource Area, 2 October 1996 to 27 May 1998 (Calculated Based on Observations within $200 \mathrm{~m}$ of Site Center. Icl = 95\% Lower Confidence Limit; ucl = 95\% Upper Confidence Limit; Icl Values Less Than Zero were Set to Zero) 48

Table 14. Mean Fatality Observed during Phase I Utilization Surveys at Tehachapi Pass Wind Resource Area, 2 October 1996 to 27 May 1998 (Calculated Based on Fatalities Found During Scheduled Carcass Searches: Icl $=95 \%$ Lower Confidence Limit; ucl = 95\% Upper Confidence Limit; Icl Values Less than Zero were Set to Zero)

Table 15. Mean Risk Observed During Phase I Utilization Surveys at Tehachapi Pass Wind Resource Area, 2 October 1996 to 27 May 1998 (Calculated Based on Observations of Use Within 200 m of Site Center and Fatalities Found During Scheduled Carcass Searches: Icl = 95\% Lower Confidence Limit; ucl = 95\% Upper Confidence Limit; Icl Values Less than Zero were Set to Zero).

Table 16. Results of the Searcher Efficiency Trials at Tehachapi by Size of Carcass and Vegetation Type

Table 17. Results of the Scavenging Trials at Tehachapi Pass by Size of Carcass and Vegetation Type. 


\section{List of Figures}

Figure 1. Major developed wind resources areas (WRA) of California .............................5 53

Figure 2. Location of geographic regions and sample site locations at Tehachapi. 54

Figure 3. Horizontal distribution of dead birds surrounding the closest turbine observed during Phase I studies at Tehachapi Pass, Wind Resource Area, 2 October 1996 to 27 May 1998. Calculated without regard to other structures and whether the turbine is the closest structure.

Figure 4. Raptor mean use by season observed during Phase I studies at Tehachapi Pass, Wind Resource Area, 2 October 1996 to 27 May 1998. Mean use calculated based on observations within $200 \mathrm{~m}$ of site center. 56

Figure 5. Corvid mean use by season observed during Phase I studies at Tehachapi Pass, Wind Resource Area, 2 October 1996 to 27 May 1998. Mean use calculated based on observations within $200 \mathrm{~m}$ of site center. 56

Figure 6. Passerine mean use by season observed during Phase I studies at Tehachapi Pass, Wind Resource Area, 2 October 1996 to 27 May 1998. Mean use calculated based on observations within 200 m of site center. 57

Figure 7. Other bird mean use by season observed during Phase I studies at Tehachapi Pass, Wind Resource Area, 2 October 1996 to 27 May 1998. Mean use calculated based on observations within $200 \mathrm{~m}$ of site center. 57

Figure 8. Total bird mean use by season observed during Phase I studies at Tehachapi Pass, Wind Resource Area, 2 October 1996 to 27 May 1998. Mean use calculated based on observations within $200 \mathrm{~m}$ of site center. 58

Figure 9. Mean use, fatality rate, and the risk indices by taxonomic group observed during Phase I studies at Tehachapi Pass, Wind Resource Area, 2 October 1996 to 27 May 1998. Mean use calculated based on observations within $200 \mathrm{~m}$ of site center.

Figure 10. Raptor mean use, fatality rate, observed/expected fatalities, and the risk indices by geographic location observed during Phase I studies at Tehachapi Pass, Wind Resource Area, 2 October 1996 to 27 May 1998. Mean use calculated based on observations within $200 \mathrm{~m}$ of site center. 
Figure 11. Corvid mean use, fatality rate, and the risk indices by geographic location observed during Phase I studies at Tehachapi Pass, Wind Resource Area, 2 October 1996 to 27 May 1998. Mean use calculated based on observations within $200 \mathrm{~m}$ of site center. 61

Figure 12. Passerine mean use, fatality rate, and the risk indices by geographic location observed during Phase I studies at Tehachapi Pass, Wind Resource Area, 2 October 1996 to 27 May 1998. Mean use calculated based on observations within $200 \mathrm{~m}$ of site center. 62

Figure 13. Other bird mean use, fatality rate, and the risk indices by geographic location observed during Phase I studies at Tehachapi Pass, Wind Resource Area, 2 October 1996 to 27 May 1998. Mean use calculated based on observations within $200 \mathrm{~m}$ of site center.

Figure 14. Total bird mean use, fatality rate, and the risk indices by geographic location observed during Phase I studies at Tehachapi Pass, Wind Resource Area, 2 October 1996 to 27 May 1998. Mean use calculated based on observations within $200 \mathrm{~m}$ of site center.

Figure 15. Total bird mean use, fatality rate, and the risk indices by size of turbine (large and small) observed during Phase I studies at Tehachapi Pass, Wind Resource Area, 2 October 1996 to 27 May 1998. Mean use calculated based on observations within 200 m of site center.

Figure 16. Raptor mean use, fatality rate, observed/expected fatalities, and the risk indices by size of turbine (large and small) observed during Phase I studies at Tehachapi Pass, Wind Resource Area, 2 October 1996 to 27 May 1998. Mean use calculated based on observations within $200 \mathrm{~m}$ of site center. 66

Figure 17. Total bird mean use, fatality rate, and the risk indices by size of turbine (large and small) observed within the West Ridge during Phase I studies at Tehachapi Pass, Wind Resource Area, 2 October 1996 to 27 May 1998. Mean use calculated based on observations within $200 \mathrm{~m}$ of site center.

Figure 18. Raptor mean use, fatality rate, observed/expected fatalities, and the risk indices by size of turbine (large and small) observed within the West Ridge during Phase I studies at Tehachapi Pass, Wind Resource Area, 2 October 1996 to 27 May 1998. Mean use calculated based on observations within $200 \mathrm{~m}$ of site center. 68 
Figure 19. Total bird mean use, fatality rate, and the risk indices by turbine type observed during Phase I studies at Tehachapi Pass, Wind Resource Area, 2 October 1996 to 27 May 1998. Mean use calculated based on observations within $200 \mathrm{~m}$ of site center.

Figure 20. Raptor mean use, fatality rate, observed/expected fatalities, and the risk indices by turbine type observed during Phase I studies at Tehachapi Pass, Wind Resource Area, 2 October 1996 to 27 May 1998. Mean use calculated based on observations within 200 m of site center.

Figure 21. Total bird mean use, fatality rate, and the risk indices by row location observed during Phase I studies at Tehachapi Pass, Wind Resource Area, 2 October 1996 to 27 May 1998. Mean use calculated based on observations within $200 \mathrm{~m}$ of site center.

Figure 22. Raptor mean use, fatality rate, observed/expected fatalities, and the risk indices by row location observed during Phase I studies at Tehachapi Pass, Wind Resource Area, 2 October 1996 to 27 May 1998. Mean use calculated based on observations within $200 \mathrm{~m}$ of site center.

Figure 23. Total bird mean use, fatality rate, and the risk indices by turbine density observed during Phase I studies at Tehachapi Pass, Wind Resource Area, 2 October 1996 to 27 May 1998. Mean use calculated based on observations within $200 \mathrm{~m}$ of site center.

Figure 24. Raptor mean use, fatality rate, observed/expected fatalities, and the risk indices by turbine density observed during Phase I studies at Tehachapi Pass, Wind Resource Area, 2 October 1996 to 27 May 1998. Mean use calculated based on observations within $200 \mathrm{~m}$ of site center.

Figure 25. Total birds mean use, fatality rate, and the risk indices by rotor swept area of turbine observed during Phase I studies at Tehachapi Pass, Wind Resource Area, 2 October 1996 to 27 May 1998. Mean use calculated based on observations within $200 \mathrm{~m}$ of site center.

Figure 26. Raptor mean use, fatality rate, observed/expected fatalities, and the risk indices by rotor swept area of turbine observed during Phase I studies at Tehachapi Pass, Wind Resource Area, 2 October 1996 to 27 May 1998. Mean use calculated based on observations within $200 \mathrm{~m}$ of site center. 76 
Figure 27. Total birds mean use, fatality rate, and the risk indices by total rotor swept area of search plot observed during Phase I studies at Tehachapi Pass, Wind Resource Area, 2 October 1996 to 27 May 1998. Mean use calculated based on observations within $200 \mathrm{~m}$ of site center.

Figure 28. Raptor mean use, fatality rate, observed/expected fatalities, and the risk indices by total rotor swept area of search plot observed during Phase I studies at Tehachapi Pass, Wind Resource Area, 2 October 1996 to 27 May 1998. Mean use calculated based on observations within $200 \mathrm{~m}$ of site center 78

\section{List of Terms}

AWEA

CEC

GIS

GPS

NREL

QA/QC

RSA

TIFF

USFWS

UTM

WEST

WRA
American Wind Energy Association

California Energy Commission

Geographical Information System

Global Positioning System

National Renewable Energy Laboratory

Quality assurance / quality control

rotor swept area

tag image file format (graphics format)

U.S. Fish and Wildlife Service

Universal Transverse Mercator System

Western EcoSystems Techology

Wind Resource Area 


\section{Avian Monitoring and Risk Assessment at the Tehachapi Pass Wind Resource Area}

\section{Introduction}

The early wind energy developments were planned, permitted, constructed, and operated with little consideration for the potential impacts to birds (Anderson et al. 1999). Observations of dead raptors at the Altamont Pass Wind Resource Area (WRA) (Anderson and Estep 1988, Estep 1989, Orloff and Flannery 1992) triggered concerns on the parts of regulatory agencies, environmental/conservation groups, wildlife resource agencies, and wind and electric utility industries about possible impacts to birds from wind energy development.

Bird fatality rates observed at most wind projects are not currently considered significant to individual bird species populations. Although many bird species have observed fatalities, raptors have received the most attention (Anderson and Estep 1988; Anderson et al. 1996a, 1996b, 1997, 1999, 2000; Estep 1989; Howell and Noone 1992; Howell 1995; Hunt 1994; Johnson et al. 2000a, 2000b; Luke and Watts 1994; Martí 1994; Orloff and Flannery 1992, 1996; and Thelander and Rugge 2000). The emphasis on raptors probably emerged for several reasons:

- Raptors appear to be more at risk for collision than other bird groups

- Raptors are symbolic and have emotional value to many Americans

- Raptors are protected under federal and state authorities, including the Federal Migratory Bird Treaty Act, and some are protected by the Bald Eagle Protection Act and Endangered Species Act; thus, companies risk violating the law.

Other WRA studies have documented deaths, primarily of songbirds (Anderson et al. 2000; Erickson et al. 2000, 2001; Higgins et al. 1995; Johnson et al. 1998, 1999, 2000a, 2000b; Orloff and Flannery 1992; Osborn et al. 1996; Pearson 1992; Thelander and Rugge 2000; Winkelman 1994) and waterbirds (Anderson et al. 2000; Erickson et al. 2001; Pearson 1992; Johnson et al. 2000a, 2000b, 2002; Winkelman 1985, 1989, 1990, 1992a, 1992b; Winkelman 1994). Bats also have been killed at wind energy facilities (Anderson et al. 2000; Erickson et al. 2000; Higgins et al. 1995, Johnson et al. 1997, 1998, 1999, 2000a, 2000b, 2003).

Generally, bat fatalities have included migratory species, and until recently have not been subject to the degree of concern associated with avian fatalities.

Avian fatalities from human caused sources have been estimated near 1 billion a year in North America alone. Power lines, buildings and windows, communication towers, vehicles and pesticides are estimated to comprise more than $82 \%$ of the total mortality. At the current level of development, wind turbines are estimated to comprise less than $0.01 \%$ of the total annual avian mortality from human-caused sources (Erickson et al. 2004). Although this proportion is extremely small, potential impacts to species or groups of concern, and proper siting of individual wind projects and turbines within wind projects, still need consideration. 
A potential cumulative impact from all sources is still a continued concern, since many bird populations are in decline throughout the United States (USFWS 2002).

The levels of concern about wind turbine impacts on birds will likely remain high until we have a better understanding of the factors related to bird fatality. Studies such as this will hopefully provide valuable information regarding avian use and fatality and help reduce the level of uncertainty with wind energy development.

The primary objective of this study was to estimate and compare bird utilization, fatality rates and collision risk indices among factors such as bird taxonomic groups, turbine types and turbine locations within the operating wind plant in the Tehachapi Pass WRA, in southcentral California between October 1996 and May 1998.

\section{Coordination and Funding}

California Energy Commission (CEC) staff and Western EcoSystems Technology (WEST, Inc.) personnel worked together on this project. Funding was provided by the California Energy Commission, the National Renewable Energy Laboratory (NREL), and the American Wind Energy Association (AWEA). Cost-sharing funds from NREL were provided starting in late 1996, when this study began at Tehachapi Pass WRA.

\section{Study Area}

The Tehachapi Pass WRA is located in south-central California (Figure 1) at elevations of 1,006 to $1,615 \mathrm{~m}$ above sea level. The natural vegetative communities are botanically and structurally diverse and complex. The Tehachapi Pass WRA falls within the Sierra Nevada subregion of the California Floristic Province, although it is also influenced by the Great Basin Province and the Desert Province. Plant species found in the Tehachapi Pass WRA are associated with the Sierra Nevada Range to the north, the Mojave Desert to the east, the Great Central Valley to the west, and California's Transverse Range to the south (Sawyer and Keeler-Wolf 1995).

Several wind energy companies operate wind plants in the Tehachapi Pass WRA (Figure 2). We focused on five companies whose wind plants occupy approximately $80 \%$ of the developed extent of the WRA. The study area included three distinct geographic locations with operating wind plants:

- The West Ridge, which was operated and/or owned by Zond Systems, Inc., at the time of the study

- The Middle Ridge, which was predominantly owned and/or operated by Cannon Energy Corporation and FloWind Corporation during the study

- The East Slope, which was predominantly owned and/or operated by Foras and SeaWest, Tehachapi, Inc., during the study. 
There were approximately 3,300 operational wind turbines within the WRA during this study, approximately 1,200 within the West Ridge and slightly more than 1,000 each within the Middle Ridge and East Slope (Table 2).

The West Ridge is heavily influenced by Central Valley grasslands, the Sierra Nevada foothills, and Sierra Nevada forest ecosystems. This location is the highest in elevation of the three study sites, and is primarily comprised of annual grassland, intersected in several locations by a sub-shrub component, wooded ravines, and seasonal stream/riparian plant communities. There are also areas of north-facing slopes that contain scrub oak chaparral, conifer, and blue oak woodland plant communities. The Middle Ridge occurs at an elevation somewhat lower than the West Ridge. This location contains components of all three major converging floristic regions. The Middle Ridge is a combination of annual and perennial grasslands, with sub-shrubs as common components. There are also small patches of Joshua trees, junipers, willows, and oaks. The East Slope is characteristic of the Desert Province and is predominantly shrubland with a significant component of perennial grasslands. Patches of junipers, Joshua trees, and creosote bushes also occur in this area.

Habitat structure is an important variable for resident and migratory bird species. Most of the vegetation in the WRA is annual and perennial grasslands or grassland with shrub or subshrub components. Ground dwelling resident bird species use these habitats for forage and nesting. Many migratory species use it for foraging habitat while passing through the area on their migrations to summer or winter areas. Diurnal and nocturnal resident and migrant species were present in the WRA.

Little is known about nocturnal and migratory bird movements through the Tehachapi area, except that turkey vultures migrate through the area by the thousands each year. Prey does not seem to be a conspicuous contributor to raptor deaths as in Altamont. There are few ground squirrels and small diurnal mammals in the Tehachapi WRA.

The WRA has four distinct seasons. Tehachapi Pass receives approximately $50.8 \mathrm{~cm}$ of precipitation from October through April on the West Ridge, which decreases because of rain shadow effects to less than $25.4 \mathrm{~cm}$ on the East Slope (Mojave Desert). Snow falls each winter. Temperatures can range from $-18^{\circ} \mathrm{C}$ to $43^{\circ} \mathrm{C}$. The WRA is windy much of the year; the predominant wind direction is from the west/northwest in the mid-spring to mid-fall and from the southeast/east during the colder months. The wind is variable, depending on weather fronts. Access within the WRA is by dirt and gravel roads. These roads are often steep, and inclement weather can make them impassible for short periods of time.

\section{Study Objectives and Key Research Questions}

The primary objective of this study was to estimate and compare bird utilization, fatality rates, and collision risk indices among factors such as bird taxonomic groups, turbine types, and turbine locations. The key questions addressed to meet this objective include the following: 
- Are there any differences in the level of bird activity, called "utilization rate" or "use," among the factors within the operating wind plant?

- Are there any differences in the rate of bird fatalities among the factors within the operating wind plant?

- Does bird use, fatality rates, or collision risk indices vary according to the geographic location, type, and size of turbine; turbine location; environmental conditions; and/or type of bird; within the operating wind plant?

- How do raptor fatality rates at Tehachapi Pass compare to other wind projects with comparable data?

\section{Methodology Development}

The methods used in this study were developed through a collaborative process that included biostatisticians and field methodology experts who represent federal, state, utility, consulting, and environmental organizations. The methods and metrics conform to those suggested in "Studying Wind Energy/Bird Interactions: A Guidance Document" (Anderson et al. 1999).

\section{Study Design}

This mensurative study (Hurlbert 1984, Morrison et al. 2001) is designed to provide statistical evidence regarding differences in fatality rates, use and collision risk indices between levels of multiple factors. The true cause of statistically significant differences cannot be determined from this study. Some factors are confounded. For example, the West Ridge area had no large tubular towers when studied and the highest fatality rates when compared to the other two areas. Therefore, geographic location is confounded with turbine type, and significant differences observed may be a result of location or turbine type. The basic experimental design is a stratified random design, with geographic location, turbine types, turbine sizes, and tower types used in defining strata.

\section{Permanent Site Selection}

In all, 201 permanent sample sites were selected (Table 2) for the location of carcass searches and bird use surveys. Each site included 1-11 turbines; 637 turbines were sampled. Sites were selected within all geographic locations (West Ridge, Middle Ridge, and East Slope) and were located at operational turbines. A stratified random sampling method was used to select the sample sites. Within each region to be sampled, turbines of the same type were assigned sequential numbers.

Turbine type consisted of six stratum:

- Large tubular turbine (horizontal axis turbine $>26 \mathrm{~m}$ rotor diameter on tubular tower)

- Small tubular turbine (horizontal axis turbine $<26 \mathrm{~m}$ rotor diameter on tubular tower)

- Large lattice turbine (horizontal axis turbine $>26 \mathrm{~m}$ rotor diameter on lattice tower)

- Small lattice turbine (horizontal axis turbine $<26 \mathrm{~m}$ rotor diameter on lattice tower)

- Windwall turbine

- Vertical axis turbine. 
At least 19 turbines of a particular type were selected randomly within each region, if that particular type had been built in a particular region. When a selected turbine was found to be non-operational, the next closest turbine or a different turbine - using the previously mentioned sampling methods - was selected.

Starting April 1, 1997, 30 additional end-row turbine sample sites were selected to provide information on end-row versus mid-row comparisons. The additional end-row turbine sites were randomly selected from all available end-row turbines. Stratification was conducted according to turbine type. Six turbines were randomly selected from all the available end-row turbines of each turbine type. Available end-row turbines included those that were not previously chosen as permanent samples or scavenging study sites. The latter criterion resulted from concern that a scavenging site may become attractive to scavengers because of the large food source and could result in higher scavenging rates of wind turbine fatalities. There was no limit on how close a new end-row turbine could be to a previously chosen permanent sample or a scavenging study site.

The sample design resulted in the following number of turbines and turbine types for the center turbine for each permanent study site (Table 3): 30 large tubular turbines; 42 small tubular turbines; 46 large lattice turbines; 27 small lattice turbines; 26 small windwall turbines; and 30 vertical axis turbines. More specifically, the design resulted in the selection of 25 large lattice turbines, 27 small lattice turbines, and 26 windwalls at West Ridge, 21 large lattice turbines, 23 small lattice turbines, and 30 vertical axis turbines at Middle Ridge, and 30 large lattice turbines and 19 small lattice turbines at East Slope. The permanent sample sites were sampled four or five times in random order from 2 October 1996 to 27 May 1998; the additional end-row turbines were sampled starting April 1, 1997.

The carcass search plot was defined as a 50-m radius circular area centered on the selected turbine, and the bird use plot was defined as variable circular plot centered at the selected turbine. The search plot could contain more than one turbine. The permanent site search plots covered approximately 400 acres or 14\% of the total search area (approximately 3,000 acres) as determined by a 50-m buffer of all turbines in the WRA.

Each permanent and end-row sample site was classified into one of three row position classifications: end-row, mid-row, and discontinuous. We used the distance D, defined as the average distance following the general contour of the topography, between turbines within the same row to determine the row position for each sample site. The following definitions were used:

End-row: A turbine at the "end" of a row that is within three rotor diameters (3D) of a turbine on one side of it, but greater than 3D from any other turbine. For a turbine that is approximately 2D-3D from its closest turbine to be considered an end-row turbine, it must follow the general contour or line of the row.

Mid-row: A turbine within a row that is no more than 3D (or $100 \mathrm{~m}$ in the case of a windwall turbine) from the next closest turbine in either direction within the row. 
Discontinuous: One or two turbines that are not within 3D of a third turbine of the same turbine type. $\mathrm{D}$ in these cases would be approximately equal to the average distance between turbines of the same model within a row within that company area. Alternatively, a turbine is considered discontinuous if it is part of a row and is approximately 2D-3D from the closest turbines in either direction of the row, but does not follow the general contour/line or configuration.

\section{Observer Detection Efficiency Study Site Selection}

Observer detection trials were conducted to estimate the probability a carcass present in a search plot would be found during a search. Nine observer detection efficiency study sites were selected subjectively according to the two primary criteria: (1) the bulk of each site had to be representative of the vegetative cover in the WRA; and (2) the sites had to be in an area that was large enough to accommodate three observer detection efficiency study sites within approximately $200 \mathrm{~m}$ of one another. Six grassland sites and three sub-shrub sites were selected. Observers conducted searches at each site.

\section{Scavenging Study Site Selection}

\section{Near-Turbine Sites}

Scavenger detection trials were conducted to estimate the length of time a carcass would remain in the WRA before being removed by scavenging. Stratification for selection of nearturbine carcass placement sites for the scavenging bias trials was conducted by geographic location. Each location was further stratified into five regions of equal size (area) or equal number of turbines. Four turbine locations were randomly selected in each region. Each turbine thus had an equal chance of being selected.

Each trial carcass was generally placed $50 \mathrm{~m}$ from its respective chosen turbine at an angle perpendicular to the general angle of the turbine row.

\section{Away-From-Turbine Sites along Roads}

Some trial carcasses were placed at least $0.4 \mathrm{~km}$ away from turbines, along lightly to moderately used roads. For carcass placement, unpaved roads away from wind turbines were driven, and trial carcasses were put out at every $0.32 \mathrm{~km}$ or $0.48 \mathrm{~km}$ interval of the road. Each available site along a driven road was used unless a site was inappropriate because of atypical vegetation or unacceptable proximity to turbines or main roads. The carcass was placed $50 \mathrm{~m}$ from the road at an angle approximately perpendicular to the road and a stake or pinflag was placed $10 \mathrm{~m}$ in a magnetic north direction from the carcass. Another pinflag was placed along the opposite side of the road from where each trial carcass was placed. 


\section{Methods}

\section{Geographical Information System}

Characteristics of the Tehachapi WRA study area were mapped using a Geographical Information System (GIS). Digital topographic maps $(1: 24,000)$ from the U.S. Geological Survey were used as base maps. These maps contained topographic information, roads, watercourses, and various other physical features. Aerial photographs of the study area were scanned into the computer in tag image file format (TIFF) and included as a GIS layer. The aerial photographs were used to identify additional features such as roads, power lines, wind turbines, and buildings not found on the base map layer. Vegetation types were outlined on the aerial photographs and confirmed by comparing the vegetation at selected ground locations with the photo-interpreted types. The vegetation types for the study area were then digitized to create a vegetation layer. Universal Transverse Mercator System (UTMs) coordinates were obtained for all turbines with a Global Positioning System (GPS) handheld unit. The UTM coordinates collected at each turbine were used to create another GIS layer that contained turbine locations. Other turbine information was attributed to each turbine in the GIS database, such as turbine manufacturer, turbine height, rotor swept area/volume, and type of tower. The GIS layers were created using Arc/Info, ArcView, and DIMPLE remotesensing image analysis software.

\section{Vegetation Types Classification}

Vegetation types (Sawyer and Keeler-Wolf 1995) were identified on the ground and on aerial photographs and transferred to a GIS information layer. The information was used to analyze habitat influence on bird use and other parameters. The vegetation type within $50 \mathrm{~m}$ of each carcass search plot center was documented, including the vegetative structure and dominant (e.g., highest percent cover overstory) and as many as two sub-dominant plant species. Four vegetation structures were identified for the Tehachapi Pass WRA: (1) grass, (2) sub-shrub, (3) large shrub, and (4) wooded. Plant groups and species within each structure are presented in Table 1.

\section{Bird Utilization Count}

Bird utilization counts were conducted from 8:00 a.m. to 12:00 p.m. for 20 months from 2 October 1996 through 27 May 1998. Each sample site was visited approximately every 6-7 weeks, and each visit consisted of two 5-minute consecutive utilization counts. Observations consisted of continuous counts of birds detected visually or audibly at any distance during the 5-minute intervals for a circular plot with the site turbine located at the plot center.

Data collected during each site visit consisted of both site and observation information. Site information included site number, observer, date, starting and ending times, and applicable weather (precipitation, fog, cloud cover, temperature, wind speed and direction, and background sound levels). Observation information included the utilization count number, starting time, a unique observation number, species, number of individuals, estimated 
distance from observer at initial sighting, estimated closest distance to observer, behavior or activity (e.g., flying, perching, soaring, hunting, foraging, height above ground, and behavior if the bird approached the turbine [i.e., within $\leq 50 \mathrm{~m}$ of the turbine]), and the type and operational status of the closest turbine to the observation. Additionally, for all observations, flight height was recorded to the nearest meter when the bird (or group of birds) was first observed and when or if they entered within $50 \mathrm{~m}$ of a turbine. Avoidance behavior (e.g., flaring, other avoidance behavior, perching) was also characterized and recorded. Comments or unusual observations were recorded in the comment section of the data form.

\section{Carcass Searches}

The objective of the carcass searches was to document bird fatalities. At each permanent site, one carcass search was conducted quarterly, and four or five searches were conducted at each site during the study. Circular plots with a radius of $50 \mathrm{~m}$ centered at each sample site (turbine) were systematically searched. The intensity of each search was vegetation dependent and typically took 30 minutes to 2 hours (i.e. searching short grassland was quicker than searching thick shrubby areas).

Data collected during each carcass search included a unique carcass number, site, date, observer, species, sex, and age when possible, time, condition (e.g., intact, scavenged, feather spot), cause of death (when possible), description of injury(ies), identification of and distance to nearby structures, distance to closest turbine, classification of closest turbine (i.e., mid-row and end-row), and distance to plot center. Comments that describe the characteristics of the carcass and indicate the cause of death or other pertinent information were also recorded. All carcasses discovered were photographed as found, plotted on a detailed map of the study area that showed the location of the wind turbines and associated facilities such as power lines and towers, and collected for species verification.

\section{Observer Detection Efficiency Study}

Circular plots $100 \mathrm{~m}$ in diameter were identified with pinflags placed at the north, east, south, and west edges. An individual, not conducting searches as a part of the trial, placed small and large bird carcasses and carcass parts at randomly selected locations within the plot. All placements were documented and then compared with the observer's findings to determine the proportion of small and large carcasses or carcass parts detected by each observer.

\section{Scavenging Bias Trials}

For each scavenging trial, 60 brown chickens and 60 chick carcasses were used to simulate large and small bird carcasses for scavenging rate comparisons near turbines and at different distances from turbines. Three independent scavenging bias trials were conducted using a total of 315 carcasses. The scavenging bias trials were conducted on 2-3 August 1996, 9-10 December 1996, and 8-9 April 1997. As many as 40 chicken and chick carcasses (20 each) were placed in each geographic location. In each location, 10 chickens and 10 chicks were placed at near-turbine sites, and 10 of each were placed at away-from-turbine locations, more than $0.4 \mathrm{~km}$ away from the nearest turbines. Because of constraints on readily accessible 
away-from-turbines sites, the goal of 20 away-from-turbine sites was not attainable at each geographic location. Because we used carcasses that were not representative of the bird species that were observed as fatalities, this information was primarily used to describe relative differences in scavenging by study area or vegetation.

\section{Statistical Analysis Methods}

\section{Bird Use}

Bird activity was described by calculating utilization rates. We defined utilization rate as the number of observations of birds divided by the number of utilization counts (surveys). Only birds visually observed within $200 \mathrm{~m}$ of the site center were considered in the calculation of mean utilization rates. Observations of birds only heard and not seen were not used in the calculation of mean utilization rates because turbine and wind noise often mask bird calls. This ensured that turbine or wind noise would not bias bird use estimates in developed WRA compared to undeveloped areas.

\section{Observed Bird Fatality Rates}

Bird fatality rate is defined as the number of unique bird carcasses found on each plot per search (50 $\mathrm{m}$ radius of focal turbine):

$$
\text { bird fatality rate }=\text { number of fatalities } / \text { number of searches }
$$

Because searches are conducted quarterly, the fatality rate used in the comparative analyses represents the observed number of fatalities per 3-month period per sample site. This fatality rate could be multiplied by four to come up with an observed annual fatality rate per search plot unadjusted for scavenging and search efficiency biases, with each search plot typically containing one or more turbines. An annual per turbine fatality rate was calculated by adjusting the annual fatality rate per search plot to account for the effective area of the wind project that was searched (14\% of the total search area within $50 \mathrm{~m}$ of turbine strings) and the interval between searches (approximately 90 days). Each search plot on average effectively covered the area around 2.2 turbines. Therefore, the annual fatality rate was calculated by:

$$
\text { annual per turbine fatality rate }=\frac{4}{2.2} \text { (no. fatalities per search) }
$$

where the factor 4 adjusts the search period to a year period and the 2.2 factor adjusts for the fact each plot effectively samples 2.2 turbines on average.

\section{Bird Collision Risk Index}

We defined an index to collision risk as the fatality rate divided by the utilization rate. For example, considering only birds observed within $200 \mathrm{~m}$ of the site center, the overall bird risk for the Tehachapi Pass WRA is:

$$
\text { bird risk index }=\frac{\text { fatality rate }}{\text { utilization rate }}
$$


Bird utilization rates and bird fatality can increase proportionately without changing the bird collision risk index. An increase or decrease in fatality, however, with no change in use causes an increase or decrease in the risk index. Similarly, an increase or decrease in use with no change in fatality causes a decrease or increase in the risk index. The bird risk index can therefore be used to compare differences for variables of interest (i.e., geographic location, taxonomic group, turbine density, row location, rotor swept area/volume, turbine size, turbine styles, and turbine type) while accounting for observed differences in use and fatality rates associated with individual values of each variable. This index is a relative number that can range from zero to a large number and is used for comparing levels of other factors such as turbine type. It should not be construed as an absolute measure of collision risk. The numerator represents a fatality rate (number of fatalities/3-month period/site). The denominator represents the number of birds observed per 5-minute period. To equate the risk index to a more direct measure of the likelihood of collision per bird observation near wind turbines, the index would need to be divided by the number of 5-minute periods within the 3month search interval. For example, a risk index of 1.0 from the equation above can loosely be interpreted in the following way: one fatality is estimated to occur in a 3-month period for every 10,800 bird observations (90 days in 3-month interval times 120 5-minute daylight periods per day) within $200 \mathrm{~m}$ of the turbine during that 3-month period. Detection biases associated with bird observations and detection and scavenging biases for fatalities would affect the risk measure.

\section{Comparison Factors and Analyses}

The primary analysis variables considered in comparing use, fatality rates, and the collision risk index are listed in Table 3. For each metric (except rotor swept area [RSA]) and variable of interest, 95\% confidence intervals were calculated. The null hypothesis of "no difference" was tested at two-tailed $\alpha$-level of 0.10 by investigating the overlap of the confidence intervals. Given the high variability in field data of this sort, we discuss statistically significant differences and trends in the data that are supported by consistent patterns across several comparisons. Linear regression was used to investigate the relationship between the fatality or collision risk rates and the RSA (RSA of turbine sampled and RSA within the 50$\mathrm{m}$ plot). Logistic regression was also used to investigate the relationship between the presence of at least one carcass at a site and the RSA (RSA of turbine sampled and RSA within the 50-m plot).

There are other factors that may be important, which we did not attempt to model. Cause of the differences is not inferred from the statistical analyses because of the observational nature of the study and the possibility of confounding factors. Professional judgment and trends in the data are the primary methods we use to interpret pattern and to make inferences regarding the results.

\section{Scavenging Bias Trials}

Scavenging rates by season and vegetation type are described by calculating the proportion of birds removed after 8 days and the estimated mean time until removal. Given the limited 
nature of these data (few trials, limited species of trial carcass), they were used only to describe the characteristics of scavenging rates, and general comparisons of rates of factors such as season.

\section{Observer Detection Bias Trials}

The observer detection probability was estimated by:

$$
p=\frac{\# \text { of carcasses detected }}{\# \text { of carcasses placed }}
$$

Given the limited nature of these data (few trials), they were used only to describe the relative efficiency of the searches and general comparisons of detection rates and the influence of factors such as season.

\section{Quality Assurance and Quality Control}

Quality assurance and quality control (QA/QC) measures were used during all stages of the project including field training, data collection, field form completeness, data entry, data analysis, and report preparation. Field forms were created, and lists of variables documented and defined for each research study. A detailed protocol (standard operating procedure) was prepared for bird utilization counts, carcass searches, scavenging bias trials, and observer detection trials. These protocols helped maintain a high level of precision and consistency in data collection.

Field personnel were trained in all field collection methods. A computerized database was created to store and retrieve field data. Personnel experienced in data entry using a predefined format to make subsequent data analysis more efficient entered data from field forms into electronic data files. Printouts of the entered data were compared with the completed and previously checked field forms to verify the accuracy of the data entries. All data entry errors were corrected.

At the end of the study, the complete database was sent to statistical personnel for additional $\mathrm{QA} / \mathrm{QC}$ and data analysis. Anomalies or inconsistencies were resolved with field staff and changes were made where necessary with the proper documentation. Results of data analysis were compared for accuracy during all stages against hand-calculations and other methods of calculation.

\section{Results}

\section{General Avian Use, Frequency Occurrence, and Species Composition}

A total of 3,318 5-minute bird utilization counts, including 1,404 at West Ridge, 992 at Middle Ridge, 922 at East Slope, and 829 carcass searches were completed in Tehachapi Pass WRA from 2 October 1996 to 27 May 1998. During the utilization counts and other observations, 47 unique species were documented in 2,882 sightings of 6,380 individuals 
(Table 4). Appendix A contains a list of the bird species observed during bird utilization surveys.

For all three geographic locations combined, 25 species were observed during spring (1 March - 15 April), 28 during summer (16 April - 30 September), 25 during fall (1 October 15 December), and 20 during winter (16 December - 28/29 February) (Table 5). The greatest number of species observed at Middle Ridge occurred during summer (20), at West Ridge also during summer (17), and at East Slope during fall (13). West Ridge tended to have a higher number of species present throughout the year, followed by East Slope. Middle Ridge showed the largest differences in numbers of species observed between seasons.

Avian use (mean number of individuals per survey) across all three geographic locations was highest in the spring (1.61), followed by fall (1.55), winter (1.20), and summer (0.93). The highest use occurred at West Ridge in spring (2.36), and the lowest use was recorded at East Slope in summer (0.35) (Tables 5 and 6).

Avian richness (mean number of species per survey) across all three geographic locations was highest in the spring (1.26), followed by fall (1.25), summer (1.20), and winter (1.16). Both the highest and lowest estimates of avian richness occurred at East Slope during spring (1.38) and summer (1.04), respectively (Table 5).

\section{Avian Use by Bird Group}

Raptor use was generally higher during fall and winter and slightly lower during spring and summer (Table 6). Corvid abundance was highest during spring and lowest during summer and fall. Passerine abundance was highest during fall and lowest during summer with similar values for spring and winter (Table 6). Passerines had the highest mean use recorded at East Slope during fall (1.65 birds/survey). There were no raptors observed during winter at East Slope. Raptor use was also lowest in the summer at East Slope.

\section{Avian Use by Species}

Overall, the most abundant avian species, based on mean number per 5-minute utilization survey, during the spring, summer, and winter was the common raven, with the horned lark being the most abundant species during the fall (Table 7). At West Ridge the common raven was the most abundant species year round. At Middle Ridge the most abundant species was the common raven during summer and winter, the European starling during spring, and the white-crowned sparrow during fall. At East Slope the most abundant species was the European starling during spring, the common raven during summer, the horned lark during fall, and the western meadowlark during winter.

The most frequently occurring avian species throughout the year was the common raven, followed by the western meadowlark in spring, fall, and winter, and the horned lark during summer (Table 8). At West Ridge the common raven was the most frequently occurring species throughout the year, followed by the western meadowlark during spring and winter, and the scrub jay during summer and fall. At Middle Ridge the common raven was again the 
most frequently occurring species throughout the year, followed by the loggerhead shrike during summer and winter, and the western meadowlark during spring and fall. At East slope the common raven was the most frequently occurring species in spring, summer, and winter, and the horned lark was the most frequently occurring species during fall.

The red-tailed hawk was the most commonly observed raptor species (Table 4), accounting for more than $60 \%$ of the observations, followed by the American kestrel (15\%). Other raptor species observed included the golden eagle (3 detections), northern harrier (2), sharp-shinned hawk (2), ferruginous hawk (2), and prairie falcon (1).

\section{Avian Flight Height Characteristics}

Flight height characteristics were calculated by taxonomic groups and geographic locations (Table 9). The overall mean flight height of bird groups for the Tehachapi Pass WRA was $22.27 \mathrm{~m}$. Overall, flight heights were highest for raptors $(53.58 \mathrm{~m})$, followed by corvids $(28.34 \mathrm{~m})$, other birds $(26.17 \mathrm{~m})$, and passerines $(7.38 \mathrm{~m})$; Middle Ridge followed the same pattern. At West Ridge the pattern was similar except other birds were observed slightly higher than corvids. At East Slope, mean flight heights were highest for corvids, followed by raptors, other birds and passerines. The highest mean flight height was observed at West Ridge $(26.19 \mathrm{~m})$, followed by Middle Ridge $(18.35 \mathrm{~m})$ and East Slope $(15.62 \mathrm{~m})$. The higher average flight heights at West Ridge may be a result of the topographic diversity as well as the higher raptor use at this location.

\section{Avian Perching Behavior}

Considering all birds, most observations of perched individuals were on vegetation (39.6\%) or the ground (18.1\%, Table 10). Power lines were the most common structure used as a perch $(11.9 \%)$. Other structure types with at least $5 \%$ of the perched bird observations were small tubular turbines $(9.5 \%)$, lattice turbines $(6.7 \%)$, and meteorological towers $(5.0 \%)$. No birds were observed perching on tall tubular turbines.

A total of 40 perching events were documented for raptors (Table 10). Power lines (poles and conductors, $27.5 \%$ ) and meteorogical towers (wires and towers, $22.5 \%$ ) comprised $50 \%$ of the perched raptor observations. Large and small lattice turbines comprised $20 \%$ of the observations, and vertical axis turbines comprised 10\% (both guy and tower observations). Two raptors were observed perching on small tubular turbines, and no raptors were observed perching on large tubular turbines. Nearly all perching events were on non-operating turbines.

\section{Avian Fatality Counts and Composition}

One hundred and twenty-seven bird fatalities representing 27 species were identified during the study period in the Tehachapi Pass WRA (Table 11, Table 12, and Appendix B). Seventy-five of 127 fatalities were found on search plots. In addition, one long-eared bat (Myotis evotis) with a fresh wound to the body was found dead $3 \mathrm{~m}$ from a turbine at West Ridge during a carcass search. 
Of the 75 fatalities found on search plots, the most commonly found avian group was other birds $(40.0 \%$, mostly unidentified birds) followed by raptors $(34.7 \%)$, passerines $(20.0 \%)$, and corvids $(5.3 \%)$. These dead birds were found $0-50 \mathrm{~m}($ mean $=20.4 \mathrm{~m})$ away from the closest turbine. When the closest structure was a turbine, dead birds were found $0-50 \mathrm{~m}$ (mean $=16.8 \mathrm{~m}$ ) away from the turbine.

Forty-four of the 127 fatalities (34.6\%) were raptors (Table 11). Raptor species with the most fatalities were the red-tailed hawk (14), great horned owl (13), and American kestrel (9). Other raptor fatalities consisted of the common barn owl (2) and one each of the following the ferruginous hawk, prairie falcon, long-eared owl, flammulated owl, an unidentified buteo, and an unidentified raptor. Only two corvid species suffered fatalities, the common raven (8) and scrub jay (2), which represented $7.9 \%$ of the total. Twenty-seven of the fatalities $(21.3 \%)$ were passerines. Passerine species with the most fatalities were the western meadowlark (6), horned lark (3), European starling (3), white-crowned sparrow (2), and dark-eyed junco (2). Other passerine fatalities consisted of one each of the chipping sparrow, Brewer's blackbird, hermit thrush, rock wren, yellow-rumped warbler, loggerhead shrike, and unidentified sparrow in addition to four unidentified passerine fatalities. Other birds comprised 46 $(36.3 \%)$ of the fatalities. Other bird species with fatalities included the rock dove (11), mourning dove (6), red-shafted flicker (3), greater roadrunner (2), chukar (2), and California quail (2). Twenty fatalities remained unidentified to taxonomic group and were grouped in the other bird category. These were typically feather spots.

Seventy of the 127 fatalities (55.1\%) were feather spots, $31(24.4 \%)$ consisted of feathers and/or bones, $13(10.2 \%)$ were intact and $12(9.5 \%)$ were dismembered. Seventy-five of the 127 bird fatalities $(59.1 \%)$ were found during scheduled carcass searches. The remaining fatalities were found by observers as they conducted other study activities or by power company employees (Appendix B). Only fatalities found during scheduled carcass searches were used to estimate fatality rates.

Fatalities were observed at $54(27 \%)$ of the 201 sites monitored. The largest number of fatalities observed at any one site was four (sites Z18, Z36, Z44), with three fatalities observed at each of two sites, two fatalities at nine sites, one fatality at 39 sites, and no fatalities at the remaining sites. Based on the 75 fatalities observed at these sites, we would expect approximately $28 \%$ of the sites to have at least one fatality under a random distribution, which suggests there was no large distinctive clustering of fatalities at a few turbines. However, factors such as scavenging and the relatively small sample of turbines compared to the total number of turbines in the wind site could mask a clustering effect.

Turbines were the closest structure that could have caused the fatality for 97 of the 127 fatalities (76.4\%). Turbines were the first or second closest structure for 118 fatalities $(92.9 \%)$. Dead birds were found $0-350 \mathrm{~m}($ mean $=25.1 \mathrm{~m})$ away from the closest turbine. When the closest structure was a turbine, dead birds were found $0-75 \mathrm{~m}(\mathrm{mean}=16.9 \mathrm{~m})$ away from the turbine. Thirty-six $(28.3 \%)$ of the 127 fatalities were found $<10 \mathrm{~m}$ from a turbine, 34 (26.8\%) from $10 \mathrm{~m}$ to $\leq 20 \mathrm{~m}, 14(11.0 \%)$ from $20 \mathrm{~m}$ to $\leq 30 \mathrm{~m}, 19(15.0 \%)$ from $30 \mathrm{~m}$ to $\leq 40 \mathrm{~m}, 16(12.6 \%)$ from $40 \mathrm{~m}$ to $\leq 50 \mathrm{~m}$, and $7(5.5 \%)$ were $\geq 50 \mathrm{~m}$ from a turbine. 
Eight fatalities $(6.3 \%)$ were associated with structures other than turbines as the two closest structures. Other structures located closest $(<40 \mathrm{~m})$ to the dead birds were distribution lines (7), meteorological towers (6), transmission lines (6), other human-made structures (4), main roads traveled $>56.3 \mathrm{kph}$ (3), fences (2), and telephone lines (1). When considering only the standardized carcass search data, there is a strong negative relationship between distance from turbine and the proportion of fatalities observed, which suggests the 50-radius plot is sufficient to document most wind turbine fatalities (Figure 3).

Cause of death could not be determined for $111(86.6 \%)$ of the 127 fatalities because of their conditions, which were influenced by the long intervals between searches. Of the 16 fatalities for which cause of death could be determined, $12(75.0 \%)$ resulted from collisions with turbines, two (12.5\%) from electrocution, and one each $(6.3 \%)$ resulted from a collision with a vehicle and a collision with a wire. One collision with a structure was observed. A western meadowlark was observed colliding with the wire of a guyed meteorological tower. The bird flew away after being approached and was not included in the carcass list.

\section{Geographic Location}

Most of the 127 avian fatalities occurred at West Ridge (91), followed by East Slope (19) and Middle Ridge (16). One additional passerine fatality was located between Middle Ridge and East Slope. Raptor fatalities were proportionately higher at East Slope (9 of 19 or $47.4 \%$ ) than at West Ridge (32 of 91 or $35.2 \%$ ) or Middle Ridge (three of 16 or $18.8 \%$ ) (Table 11). Corvids were consistently the lowest fatality group overall and at each geographical location. Passerines were higher proportionately at Middle Ridge (7 of 16 or 43.8\%) and East Slope (6 of 19 or $31.6 \%$ ) than at West Ridge (13 of 91 or $14.3 \%$ ).

\section{Standardized Bird Utilization, Fatality Rates and Risk Index Comparisons}

In this section, comparisons of bird utilization rates, fatality rates, and the risk index are made between the primary analysis factors. Bird utilization rates are compared for general analysis categories such as seasons, taxonomic groups, and geographic locations. Fatality rates and the risk index are compared for all variables except season, because searches were done quarterly and the actual season the fatality occurred could not always be determined, especially for feather spots and non-fresh carcasses. For fatality rates and the risk index, we focused on total birds and raptors.

\section{Seasons}

Bird Utilization. Mean utilization rates and $95 \%$ confidence intervals by taxonomic groups were calculated for each season (Table 13). These are depicted graphically in Figures 4-8.

In every season, use was highest for passerines, followed by corvids, other birds, and raptors (Table 13). There were some differences in the observed proportions of use by groups between seasons. The highest total use was observed during spring (1.61 birds/survey). The lowest total use was observed during summer (0.93). Spring use was significantly $(\mathrm{p}<0.10)$ 
higher than summer use, however not significantly different from fall (1.55) or winter (1.20) use.

\section{Taxonomic Groups}

Bird Utilization. The mean utilization rate by all birds over the entire Tehachapi Pass WRA was $1.25 \mathrm{birds} /$ survey. Mean utilization rates by taxonomic groups were calculated (Table 13) and are depicted graphically in the top portion of Figure 9. Overall, use was highest for passerines $(0.82 \mathrm{birds} / \mathrm{survey})$, followed by corvids $(0.32)$, other birds $(0.09)$, and raptors $(0.03)$. Use by raptors was lower (although not statistically significant) than other birds and was significantly $(\mathrm{p}<0.10)$ lower than corvids and passerines. Corvids had significantly $(\mathrm{p}<$ $0.10)$ higher use than raptors and other birds, and significantly $(\mathrm{p}<0.10)$ lower use than passerines. Use by passerines was significantly $(\mathrm{p}<0.10)$ higher than use by any other taxonomic group. Other birds had significantly $(\mathrm{p}<0.10)$ lower use than either corvids or passerines and higher, but not statistically significant different use $(p>0.10)$ than raptors.

Fatality. Total bird fatality over the entire Tehachapi Pass WRA was 0.086 carcasses/survey. Fatality by taxonomic groups is presented in Table 14. These are depicted graphically in the middle section of Figure 9. Fatality was highest for other birds ( 0.034 carcasses/survey; mostly unidentified feather spots), followed by raptors $(0.027)$, passerines $(0.017)$, and corvids $(0.008)$. Fatality of corvids was significantly $(p<0.10)$ lower than fatality of other birds and lower (although not statistically significant) than fatality of raptors. There were no other significant differences in fatality between taxonomic groups.

Risk Index. The average risk index by taxonomic groups was calculated (Table 15) and is depicted graphically in the bottom section of Figure 9.

The total bird risk index over the entire Tehachapi Pass WRA was 0.070. Risk was highest for raptors $(0.836$ carcasses/bird use unit), followed by other birds $(0.406)$, corvids $(0.025)$, and passerines $(0.021)$ (Table 15). Risk for raptors was significantly $(\mathrm{p}<0.10)$ higher than for corvids and passerines; however, raptor risk was not significantly different from risk for other birds. Corvids and passerines both had significantly $(p<0.10)$ lower risk index than other birds; however, they were not significantly different from one another.

\section{Geographic Location}

Bird Utilization. Mean utilization rates by taxonomic groups were calculated for each geographic location within the study area (Table13). These are depicted graphically in the top sections of Figures 10 - 14.

Similar patterns of use were observed at all locations. Use was highest for passerines $(0.82)$, followed by corvids $(0.32)$, other birds $(0.09)$, and raptors $(0.03)$ (Table 13). There were some differences in the observed proportions of use by groups in different locations. The highest total use was observed at West Ridge (1.64 birds/survey). Lower use was observed at East Slope (1.08); however, this difference was not significant. Total use at Middle Ridge 
$(0.95)$ was significantly $(\mathrm{p}<0.10)$ lower than West Ridge; however, it was not significantly different from East Slope.

Raptors showed similar use at both West Ridge (0.04 birds/survey) and Middle Ridge (0.04); however, this group had significantly $(p<0.10)$ lower use at East Slope $(0.01)$. The highest use for corvids was observed at West Ridge $(0.51)$. Significantly $(\mathrm{p}<0.10)$ lower use was observed at Middle Ridge $(0.25)$ and significantly $(\mathrm{p}<0.10)$ lower use was again observed at East Slope (0.11). Passerines showed no significant difference in use between West Ridge (0.94), Middle Ridge (0.61), and East Slope $(0.92)(p>0.10)$. There were no significant differences in use between West Ridge (0.15), Middle Ridge (0.05), and East Slope (0.04) for other birds $(\mathrm{p}>0.10)$.

Fatality. Mean fatality by taxonomic groups was calculated for each geographic location (Table 14) and is depicted graphically in the middle sections of Figures $10-14$.

Overall, West Ridge had the highest bird fatality ( 0.145 carcasses/survey), followed by Middle Ridge (0.053) and East Slope (0.041) (Table 14). Fatality at West Ridge was significantly $(\mathrm{p}<0.10)$ higher than fatality at either Middle Ridge or East Slope.

Patterns of fatality varied across geographic location. For West Ridge, fatality was very similar for raptors (0.056) and other birds (0.057). Lower fatality was observed for passerines $(0.025)$; however, this difference was not significant $(\mathrm{p}>0.10)$. Corvid fatality $(0.008)$ was significantly $(\mathrm{p}<0.10)$ lower than either raptor or other bird fatality; however, corvid fatality was not significantly different from passerine fatality. For Middle Ridge, fatality was highest for other birds (0.024), followed by corvids (0.014), passerines (0.009), and raptors (0.006). None of the observed fatality rates by taxonomic group were significantly different among groups. For East Slope, similar mortalities were observed for raptors (0.012), passerines (0.016), and other birds (0.012). No corvid fatalities were observed at East Slope.

Raptors had significantly $(\mathrm{p}<0.10)$ higher fatality at West Ridge $(0.056$ carcasses/survey) than either Middle Ridge (0.006) or East Slope (0.012). Raptor fatality at Middle Ridge was not significantly different than fatality at East Slope. A chi-squared test revealed that there was a significant difference between the proportion of raptor fatalities found at the geographic locations $\left(\chi^{2}=19.55, \mathrm{df}=2, \mathrm{p}=0.0001\right)$. The highest fatality for corvids was observed at Middle Ridge (0.014); however, fatality was not significantly different at Middle Ridge than that observed at West Ridge (0.008) or East Slope (0). Passerines showed no significant differences in fatality between West Ridge (0.025), Middle Ridge (0.009), and East Slope (0.016). The highest fatality was observed for other birds at West Ridge (0.057). Lower fatality was observed at Middle Ridge $(0.024)$ and significantly $(\mathrm{p}<0.10)$ lower fatality was observed at East Slope (0.012). There was no significant difference in fatality between Middle Ridge and East Slope for other birds $(\mathrm{p}>0.10)$.

Risk Index. The average risk index by taxonomic groups was calculated for each geographic location (Table 15), and is depicted graphically in the bottom sections of Figures $10-14$. 
Overall, West Ridge had the highest bird risk index (0.090 carcasses/bird use unit), followed by Middle Ridge (0.056) and East Slope (0.038) (Table 15). Patterns of the risk index for individual groups of birds varied across geographic location. For West Ridge, raptors had the highest risk index (1.421 carcasses/bird use unit). A lower risk index was observed for other birds $(0.403)$ and a significantly $(\mathrm{p}<0.10)$ lower risk index was observed for corvids $(0.015)$ and passerines (0.026). The other bird risk index was also significantly $(\mathrm{p}<0.10)$ higher than risk index observed for both corvids and passerines. Corvid and passerine risk were not significantly different from one another $(\mathrm{p}>0.10)$. For Middle Ridge, the risk index was highest for other birds $(0.487)$, followed by raptors $(0.156)$, corvids $(0.055)$, and passerines (0.015). None of the observed risk index estimates by taxonomic group were significantly different from one another. For East Slope, the risk index was highest for raptors (1.187), followed by other birds (0.279), and passerines (0.018). No corvid fatalities were observed at East Slope therefore, the risk index calculated for corvids was zero. Despite the large differences in mean risk index estimates there were no significant differences observed by taxonomic group for East Slope $(\mathrm{p}>0.10)$.

Raptors had a significantly $(\mathrm{p}<0.10)$ higher risk index at West Ridge $(1.421$ carcasses/bird use unit) than Middle Ridge (0.156). The risk for raptors at East Slope (1.187) was not significantly different than either West Ridge or Middle Ridge. The highest risk index for corvids was observed at Middle Ridge (0.055); however, risk was not significantly different at Middle Ridge than that observed for West Ridge (0.015). The risk index was zero for corvids at East Slope because no corvid fatalities were detected at that location.

Passerines showed no significant differences in the risk index between West Ridge (0.026), Middle Ridge (0.015), and East Slope (0.018). The highest risk index observed for other birds was at Middle Ridge (0.487). A lower risk index was observed at both West Ridge $(0.403)$ and East Slope (0.279). There were no significant differences in the risk index by location for other birds $(p>0.10)$.

\section{Turbine Size}

Fatality rates and the risk index for large ( $\geq 26 \mathrm{~m}$ rotor diameter) and small $(<26 \mathrm{~m}$ rotor diameter) turbines are standardized only to a per turbine basis. Fatality and risk are expected to be higher for larger turbines because of their larger rotor diameter. Comparisons on a per rotor swept area basis are found in those sections below.

Fatality. Without adjusting for RSA, large turbines had a slightly higher bird fatality rate $(0.085 /$ search $)$ than small turbines $(0.071)$, although the difference was not statistically significant based on the confidence intervals $(p>0.10$, Figure 15). A chi-squared test of raptor fatality rates at the large and small turbines was also not significant $\left(\chi^{2}=0.34, \mathrm{df}=1\right.$, $\mathrm{p}=0.5580)$ (Figure 16). Within all taxonomic groups, except passerines, the fatality rate at large turbines was higher than at small turbines, although none of the differences were statistically significant. The influence of more than a single turbine in a plot could affect the results of this study. Additional information regarding this is in the Rotor Swept Area and Turbine Density sections. 
Within the West Ridge there are only lattice structures. Comparisons of bird fatality rates of the turbines in the West Ridge show slightly higher all bird and raptor fatality rates at larger turbines compared to smaller turbines (Figures 17 and 18), but the differences were not statistically significant. Rotor swept area of the larger turbines in this comparison are two to three times larger than the rotor swept area of the smaller turbines, and therefore, estimates on a rotor swept area equivalence basis are lower for the large turbines.

Risk Index. Without adjusting for RSA, larger turbines had a higher bird risk index (0.072) than smaller turbines $(0.053)$, although the difference was not statistically significant $(\mathrm{p}>$ 0.10 , Figure 15$)$. The raptor risk index was slightly higher for small turbines $(0.968$ versus 0.807), but was not statistically significant. Within the West Ridge, there are only lattice structures, and these comparisons are discussed in the Turbine Types section.

\section{Turbine Types}

Fatality. Overall, fatality rates were highest for windwall turbines $(0.131 / \mathrm{search})$ followed by large lattice turbines $(0.123)$, small lattice turbines $(0.109)$, vertical axis turbines $(0.083)$, small tubular turbines (0.048), and large tubular turbines (0.027). Confidence intervals for all estimates overlapped, which indicates no statistically significant differences (Figure 19). There was a similar pattern for raptors. The highest fatality rate occurred with windwall turbines (0.069), followed by large lattice turbines (0.045), small lattice turbines (0.027), and small tubular turbines (0.019). Large tubular and vertical axis turbines had no observed raptor fatalities. None of the differences were statistically significant (Figure 20). It is important to note that no raptors were observed at the large tubular towers, and that these towers are in the East Slope area, which had very low raptor use. A chi-squared test comparing fatality rates of only tubular and lattice towers was significant $\left(\chi^{2}=4.64, \mathrm{df}=1, \mathrm{p}\right.$ $=0.0312$, Figure 20).

Within the West Ridge, only lattice structures exist. Overall fatality rates for the large lattice structures were nearly twice the rate of the small lattice turbines $(0.20$ versus 0.12$)$, but the difference was not statistically significant. Passerine fatality rates were slightly higher for larger turbines (0.037-0.030) and not statistically significant. Raptor fatality rates were nearly three times higher at the large lattice turbines than at the small lattice turbines; again the difference was not statistically significant (Figure 18). This large difference may be explained primarily by the higher raptor utilization rate at the large lattice sites compared to raptor use at the small lattice sites (see Risk Index section below). Within the Middle Ridge, the three turbine types sampled included vertical axis turbines, large lattice turbines, and small tubular turbines. The highest overall fatality rate occurred at VAT turbines $(0.083 / \mathrm{search})$ followed by small tubular turbines $(0.035)$ and large lattice turbines $(0.031)$. The same pattern was observed for raptors and passerines.

Risk Index. Overall, the average risk index was highest for windwall turbines (0.107), followed by large lattice turbines $(0.102)$, vertical axis turbines $(0.070)$, small tubular turbines (0.060) small lattice turbines (0.049), and large tubular turbines, although confidence intervals for all estimates overlapped and indicated no statistically significant differences (Figure 19). The raptor risk index was highest at windwall turbines (3.176), 
followed by small tubular turbines (1.021), small lattice turbines (0.917), large lattice turbines (0.879), with no raptor fatalities and subsequently 0 for an estimate of the risk index at the large tubular and vertical axis turbines (Figure 20). No raptor carcasses were found at the large tubular towers and these towers are in the East Slope area, which had very low raptor use.

Within the West Ridge, the mean overall risk index was highest for the large lattice turbines followed by windwall turbines $(0.107)$ and small lattice turbines $(0.052)$. The mean raptor risk index was highest for the windwall turbines followed by very similar estimates for large lattice turbines and small lattice turbines. The mean passerine risk index was highest for large lattice turbines $(0.050)$ followed by small lattice turbines $(0.020)$, and wind wall turbines $(0.013)$.

\section{Row Location}

Fatality. Overall, mean fatality rates at mid-row sites were twice as high as fatality rates at end-row sites, but not quite significantly different (Figure 21). For raptors, the mean fatality rate at mid-row sites was three times higher than at end row sites (Figure 22). A chi-squared test revealed that there was a significant difference between the proportion of fatalities found at the different row locations $\left(\chi^{2}=5.10, \mathrm{df}=2, \mathrm{p}=0.0779\right)$. This pattern is likely partially explained by the fact that mid-row sites often have other turbines within $50 \mathrm{~m}$ in both directions, while end-row turbines often have other structures in only one direction.

This same pattern was apparent at the West Ridge. Although this pattern is likely partially explained by the influence of more turbines, possibly causing fatality at the mid-row permanent site location, the result that end-row turbines showed higher fatality at Altamont Pass WRA was not apparent in this study.

Risk Index. Patterns in relationships between row location and the risk index were similar to those for fatality, but again not significantly different. The estimate of risk for mid-row turbines was greater than for end row turbines (Figures 21 and 22).

\section{Turbine Density}

Fatality. Overall mean fatality rates increased with increasing turbine densities, with high turbine density fatality rates of 0.136 , followed by medium density $(0.075)$, low density (0.066), and very low density (one turbine within $100 \mathrm{~m})(0.029)$; none of the differences were statistically significant (Figure 23). This gradient trend was also apparent for raptors (Figure 24), but again with no significant differences. A chi-squared test revealed a significant difference between the proportion of fatalities found at the different turbine densities $\left(\chi^{2}=14.30, \mathrm{df}=3, \mathrm{p}=0.0025\right)$.

Risk. Overall risk when considering all groups showed a somewhat similar gradient trend with the highest risk at high density turbine plots $(0.117)$ and the lowest risk at plots with one turbine within $50 \mathrm{~m}(0.015)$. This difference was statistically significant $(\mathrm{p}<0.10)$. 


\section{Rotor Swept Area}

Fatality. Overall mean fatality rates did not increase or decrease consistently as the rotor swept area (RSA) of the permanent site turbine or the combined RSA of the turbines within the search plots increased (Figures 25 and 27). A similar result was observed for raptors (Figures 26 and 28). A chi-squared test revealed no significant difference between the proportion of raptor fatalities found at the different RSA of the center turbine of each plot $\left(\chi^{2}\right.$ $=2.04, \mathrm{df}=3, \mathrm{p}=0.5650)$. The chi-squared test for RSA for the entire search plots revealed a significant difference between the proportion of raptor fatalities found $\left(\chi^{2}=8.23, \mathrm{df}=3, \mathrm{p}\right.$ $=0.0408$ ). Slope coefficients for linear regression analyses of the fatality rates against the RSA of an individual turbine and of the RSA of all turbines within $50 \mathrm{~m}$ of the center of the permanent site for all birds and raptors were not significantly different than zero $(p>0.10)$.

Risk Index. The overall risk index when considering all groups showed no consistent pattern as RSA for the turbines and RSA for the sites increased. The highest risk for RSA for the center turbine occurred in the 573-616 category $(0.078)$ and the lowest risk occurred in the 1195 category ( 0.033$)$, but this difference was not statistically significant $(\mathrm{p}>0.10)$. The highest risk for RSA for the site occurred in the 1301-1900 category (0.109) and the lowest risk occurred in the 801-1300 category (0.042). Again, this difference was not statistically significant $(p>0.10)$. Slope coefficients for linear regression analyses of the risk rates against the RSA of an individual turbine and of the rotor swept area of all turbines within 50 $\mathrm{m}$ of the center of the permanent site for all birds and raptors were not significantly different than zero $(p>0.10)$.

\section{Observer Detection Rates}

Two observer efficiency experiments were conducted: one on 20-22 August 1996 and one on 28-30 April 1997. A total of 407 birds were placed in the field for observers to either detect or not detect. Estimates of the probability of an observer detecting an available carcass or part by experiment, size (small and large), and vegetation (small shrubs and grass), as well as across experiments and overall detection rates are found in Table 16. No significant differences in probability of detection estimates were observed during the first experiment for any of the comparisons. During the second study, small birds and parts of birds were significantly less detectable than large birds in both vegetation types. The two vegetation types were not significantly different from one another for small and large birds, because of tall green grass in all vegetation types.

Overall, observers detected $73 \%$ of the carcasses/parts placed in the field. Large carcasses/parts were detected $84 \%$ of the time in small shrub vegetation, and $81 \%$ in grass vegetation. Small carcasses/parts were detected $66 \%$ of the time in small shrub vegetation, and $60 \%$ in grass vegetation. Overall, small birds/parts were significantly less detectable than large birds for both vegetation types $(\mathrm{p}<0.10)$. There were no significant differences in detectability between the vegetations for either small or large birds/parts. 


\section{Scavenging Rates}

Three scavenging experiments were conducted, one on 2 and 3 August 1996, one on 9 and 10 December 1996, and one on 8 and 9 April 1997. A total of 315 carcasses were used to estimate scavenging rates (Table 17). Primary analysis variables compared include placement (within $50 \mathrm{~m}$ from turbines versus $\geq 400 \mathrm{~m}$ from turbines), season, study area, carcass size (small and large), and carcass color (cryptic versus non-cryptic). Overall, $96 \%$ of the carcasses were removed 8 days after placement (excludes carcasses available after day 4 that were not checked). The estimated proportion of fatalities removed by day 8 varied little by the primary analysis variables. The mean time to removal estimate was less than 3.20 days, with an overall average of 2.62 days ( $95 \%$ confidence interval $[2.35,2.89])$.

\section{Proximity to Turbines}

The mean removal time for carcasses near turbines was higher than away from turbines (2.89 days versus 2.31 days), but not quite significantly different $(p>0.10)$ based on overlapping 95\% confidence intervals (Table 17).

\section{Geographic Location}

The mean removal time was lowest in the West Ridge area (2.17 days), followed by Middle Ridge ( 2.70 days) and East Ridge (3.03 days). None of the means were significantly different based on the confidence intervals, although the confidence intervals overlapped only slightly between the West Ridge and East Slope $(0.10<\mathrm{p}<0.15)$.

\section{Season}

Mean removal time was lowest during the August trial (2.20 days), followed by April (2.55 days) and December (3.13 days). The difference between August and December is considered statistically significant $(\mathrm{p}<0.10)$.

\section{Size of Carcass}

Mean removal time was significantly lower for large carcasses (2.12) compared with small carcasses $(3.10$ days, $p<0.10)$. This may be partially attributable to the fact that most of the large carcasses were much more visible to ravens and raptors or diurnal predators.

\section{Color}

Mean removal time was higher for cryptic colored carcasses (2.97 days) compared with noncryptic colored carcasses ( 2.45 days), although this difference was not statistically significant $(\mathrm{p}>0.10)$. 


\section{Annual Fatality Estimates}

This study was not specifically designed to provide standardized estimates of avian fatalities and the wide interval between searches ( 90 days) leads to a high level of uncertainty in the fatality estimates. The unknown impact scavenging has on the fatality estimates could greatly impact the fatality estimates. With these obvious caveats in mind, the unadjusted estimate of raptor fatalities for the wind resource area is 0.047 per turbine per year. The average nameplate output of the turbines in our sample was $0.19 \mathrm{~kW}$ yielding an estimate of 0.25 raptor fatalities per MW per year unadjusted for searcher efficiency bias and 0.3 per MW per year adjusted for searcher efficiency bias.

\section{Discussion, Conclusions, and Recommendations}

Raptors appear to be more susceptible to collision with turbines than other birds at Tehachapi Pass, a pattern also observed at Altamont Pass (Thelander et al. 2003). Fatality rates and the risk index are clearly higher for raptors than the other bird groups. Flight height characteristics support this result, because a large majority of raptors observed were within the typical heights of turbine rotors. Many studies of avian use at wind projects (e.g., Anderson et al. 2004; Johnson et al. 2000a, 2000b; Thelander et al. 2003; Young et al. 2003) have documented raptors flying consistently at rotor swept heights of wind turbines, while resident passerines observed during the day were typically observed at lower flight heights. Flight height characteristics alone do not necessarily equate to risk, and do not account for avoidance behaviors of birds. Fatality composition from newer wind projects outside California show a much lower percentage of raptors, and more passerines, including apparent nocturnal migrants (Erickson et al. 2002).

Raptor use is the clearest factor related to raptor fatality at Tehachapi Pass. West Ridge had the highest raptor use and by far the highest fatality rates; Middle Ridge had moderate raptor use and moderate fatality rates and East Slope had very low raptor use and very low raptor fatality rates. At a macro scale, raptor use of a site still appears to be one of the most important factors that can be easily measured and is generally related to risk of collision. At this large wind site, there were differences in raptor use geographically that could be measured and were related to fatality rates. These results support the collection of baseline data in diverse and large wind projects for use in estimating locations of least impact.

When controlling for raptor use by calculating the risk index, very few differences (statistical differences or patterns) in the effects of turbine characteristics were apparent. The statistical power for detecting these differences is low as a result of confounding of variables and relatively low fatality rates. There was a pattern of higher fatality rates at larger turbines, but when the fatality rates and collision risks were adjusted by rotor swept area (RSA) or turbine density, those differences were reduced, and in some cases the fatality rates for smaller turbines on a RSA equivalence basis were higher than for the larger turbines. Theses patterns do not suggest higher raptor fatality rates on a per rotor swept area equivalence basis for larger turbines. Some studies have suggested a lower raptor fatality rate for larger turbines on a per rotor swept area basis. Howell (1997) examined differences in fatality rates between 
56-100 lattice and KVS-33 lattice turbines at Altamont Pass and Montezuma Hills. The overall fatality rates for the 56-100 downwind turbines on a per turbine basis were higher than the $33 \mathrm{~m}$ rotor diameter, suggesting in this case, that mortality was not related to rotor swept area. Other studies at Altamont have suggested a higher golden eagle fatality rate for the 56-100 turbines compared to other turbine types (Hunt 2002), possibly because of the closer proximity of the blades to the ground and the foraging behavior of golden eagles (i.e., they often forage within $3 \mathrm{~m}$ of the ground).

Most studies at new generation wind projects do not have different size turbines in the same WRA, greatly limiting the ability to infer differences in impacts among turbine sizes. Studies in Minnesota (Johnson et al. 2002) suggest there may be some relationship between the rotor swept area and fatality. Rotor swept area for larger turbines on the site (using 47-m rotor diameter) is approximately two times the area for a smaller 33-turbine on the site, and all bird fatality rates were estimated to be approximately three times higher for the larger turbine type. Most of the observed differences could be attributed to a higher rate of passerine casualties at the larger turbines, although the differences were not statistically significant. Other factors such as differences in habitat and avian use could also have been a factor in these differences.

Taller turbines may impact more nocturnal migrating birds that typically fly at altitudes much higher than small older generation turbines. While there have been numerous single fatality events recorded at communication structures that document several hundred avian fatalities in one night, there have been only two events reported, both reasonably small, at U.S. wind generation facilities. Fourteen nocturnal migrating passerines were found dead at two turbines during a single night at the Buffalo Ridge, Minnesota, Windplant during spring migration. Approximately 25-30 nocturnal migrating passerines were observed at three turbines and a lighted substation at the Backbone Mountain, West Virginia, facility following one or two nights of foggy weather. Strong evidence suggests the sodium vapor lamps at the substation were the primary attractant, and few migrant fatalities were found after the lights on the substation were turned off.

Many reports and studies have suggested that turbines on lattice towers may be associated with higher fatality rates than comparable tubular tower turbines (Curry and Kerlinger 2000; Hunt 2002; Orloff and Flannery 1996; Rugge 2001) because of the increased perching opportunities on horizontal lattice towers, which are thought to increase the number of fatalities. In this study, tubular towers have lower estimated fatality rates than lattice towers in general, but the true cause of the difference cannot be determined. Geographic location is highly confounded with tower type, since all turbines studied in the West Ridge were lattice and all turbines studied in the Middle Ridge were tubular and highest raptor use and fatality occurred in the West Ridge. Recent studies by Thelander et al. (2003) showed higher fatality rates at tubular towers, although turbine size differences between lattice and tubular towers were not taken into account. Our study and the recent studies at the Altamont suggest that tower type is not likely to be related to collision risk at sites where perch sites are abundant. However, our data do suggest a higher rate of perching behavior by raptors and small birds on small and large lattice turbines, and small tubular turbines compared to tall tubular turbines, with most perching occurring on turbines not operating. Similar results have been 
observed by Thelander (personal communications), where nearly all the perching occurred on turbines that were not operational. Perching structures for raptors and other large birds are very abundant at large older wind projects like the Altamont Pass, Tehachapi Pass, and San Gorgonio, with overhead lines and non-operational turbines. It is plausible that presence of structures such as lattice turbines and overhead lines that provide perches for raptors and other birds at sites where perch sites are limited could increase use of the sites and lead to higher mortality, although this has not been tested.

Fatalities were observed at 54 of the 201 sites monitored. The largest number of fatalities observed at any one site was four. Based on the 75 fatalities observed at these sites, we would expect approximately $28 \%$ of the sites to have at least one fatality under a random distribution. This pattern of no distinctive clustering of fatality locations at a particular turbine suggests there is no single site sampled that has a very high fatality rate compared to the other sites sampled. A similar result was observed at Altamont Pass (Thelander et al. 2003) where the number of fatalities at turbines was similar to a random distribution. However, factors such as scavenging and the relatively small sample of turbines compared to the total number of turbines in the wind site could mask potential differences. This does not imply that factors such as location of turbine or turbine string are not related to fatality rates.

There were apparent differences in collision risk among different avian groups. Ravens and turkey vultures had low fatality and relatively high use, suggesting they are not very susceptible to collisions. This was also observed at Altamont (Orloff and Flannery 1992, 1996). Red-tailed hawks, great horned owls, and American kestrels appeared to show the highest risk of collision.

We did not attempt to make estimates of annual bird fatality estimates for the developed Tehachapi Pass WRA because of the extremely high uncertainty surrounding the long search intervals (90 days) and the unknown impact of scavenging rates. We did report unadjusted annual raptor per turbine and per MW fatality estimates, because the corrections for large birds for scavenging and searcher efficiency have been much less than for small birds.

Studies at the Altamont and San Gorgonio have presented unadjusted rates using reasonably similar methods. This study suggested an estimate of 0.04 raptors per turbine per year or 0.20 raptor fatalities per MW per year. Unadjusted estimates from recent studies at the Altamont Pass was 0.10 raptors per turbine per year and $1-1.23$ raptors per MW per year. Unadjusted estimates from studies of 56-100 turbines at Montezuma Hills were 0.05 per turbine per year, or 0.50 per MW per year (Howell 1997). Raptor use (including Vultures) at Tehachapi Pass is estimated to be much less than at the Altamont Pass and Montezuma Hills, but higher than San Gorgonio (Erickson et al. 2002). The West Ridge, where the highest raptor fatality rates were observed at Tehachapi Pass WRA, was estimated to be approximately half the estimate from the Altamont Pass.

In future studies at Tehachapi Pass, we would recommend additional scavenging trials be conducted, and using bird species that are more representative of the species/groups found in the area. If raptors are the target of the research, raptors should be used in the trials. We would also recommend that searches be conducted more frequently. Initial scavenging studies should be used to direct how often a plot is to be searched. Estimating scavenging 
rates is vital in estimating fatality rates (Erickson et al. 2000). It is less vital in a study like this when comparing indices among levels of several factors. We did need to assume similar average scavenging rates among the levels of the factors studied (e.g., geographic location). The estimated scavenging rates are higher than those recorded at several other wind projects (Morrison 2002), but may be influenced by the species used (chickens). At the newly constructed Vansycle windplant located primarily in wheat fields, small carcasses lasted on average 15.0 days, and large carcasses lasted on average greater than the search interval of 28 days (Erickson et al. 2000). At the Buffalo Ridge Windplant, small carcasses persisted on average 4.7 days, whereas small birds at Foote Creek Rim persisted 12.2 days. Some other scavenging studies have observed high rates of scavenging such as those estimated at Tehachapi. Wobeser and Wobeser (1992) reported that nearly 80\% (79.2) of the chicks placed in a mixed grazed pasture were removed within 24 hours. In France, Pain (1991) estimated duck carcasses lasted an average of 1.5 days in open vegetations, whereas those concealed by vegetation or those in water lasted 3.3-7.6 days. In one orchard, scavengers removed all 25 of the placed carcasses within 24 hours, with lower rates in the other orchards studied.

The scavenging bias trials in our study were limited because of their relatively small sample size and the species of birds used (chickens). It is also believed scavengers may use scent and visual clues to locate trial carcasses, which inflates scavenging rates above rates for actual wind turbine carcasses. The observer detection trials were limited in scope and sample size.

This was not a manipulative experiment, but an observational study (Hurlbert 1984, Morrison et al. 2001) designed to provide statistical evidence regarding differences in fatality rates, use, and collision risk between levels of factors such as geographic location, turbine size, and tower type. Actual cause of statistical differences or consistent patterns in the results cannot be statistically determined from this study. For example, differences in raptor fatality rates were observed between the West Ridge and the East Slope. These differences may be a result of factors not controlled for. In a true manipulative experiment, random assignment of treatments (e.g., turbine type) to experiment units (plots) would have provided stronger inferences towards cause of differences. Although this is important to acknowledge, it is also important to acknowledge that nearly all studies at wind projects and most field studies in general are observational studies with no control over assignment of treatments (e.g., tower type) to experimental units. In observational studies, professional opinion based on patterns observed in the data, and knowledge of the subject matter, are used to make conclusions. Confirming patterns from other studies conducted at other wind sites strengthens our knowledge.

Most fatality studies (e.g., Orloff and Flannery 1992, Thelander et al. 2003, Erickson et al. 2003) are designed to estimate fatality rates for the wind project, and searches of turbines are usually conducted on a much more frequent interval (e.g., weekly, twice monthly) than the interval used in our study. We would recommend much higher search frequency (e.g., monthly or twice monthly at a minimum) and a larger sample size. In addition, at sites where turbines within strings are closer together than two times the fatality plot search radius, we would recommend searching entire turbine strings, and not individual turbines. 


\section{Acknowledgments}

We would like to thank contributing authors Leslie Backus, John Cleckler, Andie Lueders, Gabriel Mayorga, Julie Schneider, and Ginger Nuhn. We would like to thank the California Energy Commission, the National Renewable Energy Laboratory, and the American Wind Energy Association for funding support. We thank Dave Maul, Jim Brownell, Bob Haussler, and Bob Therkelsen of the California Energy Commission staff for their advice, guidance, and support on this project. We thank the commissioners and the executive office of the California Energy Commission for their support of this project. Thanks to Rick York who continues to provide botanical expertise to the project. Thanks to Linda Spiegel for assisting with various aspects of this study. Larry Mayer, Mike Morrison, and Sheila Byrne were instrumental in developing the methodology for which we are grateful. We also thank them for their continued involvement. We are grateful for assistance from Robert Thresher, Karin Sinclair, and Holly Davis at the National Renewable Energy Laboratory. We appreciate the efforts of Diana Watkins of the California Energy Commission's library for her efficient assistance in obtaining literature and other publications for this project. During the course of the Phase 1 research at Tehachapi Pass, Steve Ugoretz, and Bill Kendall have made many helpful suggestions, and we thank them for their advice. Thanks to Jennifer Noone, Jean Moore, Clark Moore, Jon Hammond, Dan Wagster, Nina Goss, Judi Efhan, Buddy Anderson, Bert Fegg, Dave Consoli, and Ron Cole. Without the cooperation of the wind industry there would be no project. We would like to thank Randy Swisher and Tom Gray of the American Wind Energy Association for their support. We thank Cannon Energy Corporation, FloWind Corporation, Foras Inc., SeaWest of Tehachapi, Inc., and Zond Systems, Inc. for their support and for allowing us access to the operating wind farms they own and/or operate. There are a number of persons at these companies we would like to thank and apologize for those we have overlooked. Thanks to Fred Beasom and Craig Loke of Cannon Energy Corporation, Dave Brown of FloWind Corporation; Mike Azeka of SeaWest, Inc.; Sean Roberts, Wayne Barwikowski, Maggie Ganczak, and Richard Ledwidge of SeaWest Tehachapi, Inc.; and Hap Boyd, Al Davies, Tom Biernett, John Nemila, and Loretta Haynes of Zond Systems, Inc. We thank Chuck Nelson and Chris Crown of the California State University, Chico, Geographic Information Center for their assistance with GIS mapping for this project. We also thank Neil Flagg for his GIS and GPS assistance on the project. We thank Denise Bell and Alice Egelston of the California State University, Bakersfield Foundation for their assistance. 


\section{Literature Cited}

Anderson, R.L. and J.A. Estep. 1988. Wind energy development in California: impacts, mitigation, monitoring, and planning. California Energy Commission, Sacramento. 12 pp.

Anderson, R.L., J. Tom, N. Neumann, J. Noone, and D. Maul. 1996a. Avian risk assessment methodology. Pp. 74-87 in Proceedings of the National Avian-Wind Power Planning Meeting II. National Wind Coordinating Committee/RESOLVE. Washington, D.C.

Anderson, R.L., J. Tom, N. Neumann, and J.A. Cleckler. 1996b. Avian monitoring and risk assessment at Tehachapi Pass Wind Resource Area, California. Staff Report to California Energy Commission, Sacramento, CA, November 1996. 40pp.

Anderson, R.L., H. Davis, W. Kendall, H. Drive, L.S. Mayer, M.L. Morrison, K. Sinclair, D. Strickland, and S. Ugoretz. 1997. Standard metrics and methods for conducting avian/wind energy interaction studies. Pp. 265-272 in Proceedings of the 1997 American Wind Energy Association Annual Meeting. American Wind Energy Association, Washington, D.C.

Anderson, R.L., M. Morrison, K. Sinclair, and D. Strickland. 1999. Studying wind energy/bird interactions: A guidance document. National Wind Coordinating Committee/RESOLVE, Washington, D.C. 87pp.

Anderson, R.L., D. Strickland, J. Tom, N. Neumann, W. Erickson, J. Cleckler, G. Mayorga, G. Nuhn, A. Leuders, J. Schneider, L. Backus, P. Becker and N. Flagg. 2000. Avian monitoring and risk assessment at Tehachapi Pass and San Gorgonio Pass wind resource areas, California: Phase 1 preliminary results. Pp. 31-46 in Proceedings of the National Avian-Wind Power Planning Meeting III. National Wind Coordinating Committee/ RESOLVE. Washington, D.C.

Anderson, R.L. W.P. Erickson, M.D. Strickland, M. Bourassa, K.J. Bay and K.J. Sernka. 2004 in review. Comparison of avian use, fatality and risk at the Tehachapi Pass and San Gorgonio wind resource areas NREL.

Curry, R.C. and P. Kerlinger. 2000. Avian mitigation plan: Kenetech model wind turbines, Altamont Pass WRA, California. Pages 18-27 in Proceedings of National Avian-Wind Power Planning Meeting III, San Diego, California, May 1998. Prepared for the Avian Subcommittee of the National Wind Coordinating Committee by LGL Ltd., King City, Ont., 202 pp.

Erickson, W.P., G.D. Johnson, M.D. Strickland, and K. Kronner. 2000. Avian and bat mortality associated with the Vansycle Wind Project, Umatilla County, Oregon: 1999 study year. Technical Report prepared by WEST, Inc. for Umatilla County Department of Resource Services and Development, Pendleton, Oregon. 21 pp. 
Erickson, W.P., G.D. Johnson, M.D. Strickland, D.P. Young, Jr., K.J. Sernka, and R.E. Good. 2001. Avian Collisions with Wind Turbines: A Summary of Existing Studies and Comparisons to Other Sources of Avian Collision Mortality in the United States. National Wind Coordinating Committee Publication. http://www.nationalwind.org/pubs/default.htm

Erickson, W.P., G. D. Johnson, D. P. Young, Jr., M. D. Strickland, R.E. Good, M. Bourassa, K. Bay. 2002. Synthesis and Comparison of Baseline Avian and Bat Use, Raptor Nesting and Mortality Information from Proposed and Existing Wind Developments. Technical Report prepared for Bonneville Power Administration, Portland, Oregon.

Erickson, W.P., J. Jeffrey, K. Bay and K. Kronner. 2003. Wildlife Monitoring for the Stateline Wind Project. Results for the Period July 2001, December 2002. Technical report prepared for the Stateline Technical Advisory Committee and the Oregon Office of Energy.

Erickson, W.P., G.D. Johnson, and D.P. Young. 2004. In press. Summary of anthropogenic causes of bird mortality. Proceedings of the 2002 International Partners in Flight Conference, Monterrey, California.

Estep, J. 1989. Avian mortality at large wind energy facilities in California: identification of a problem. Staff report no. P700-89-001. California Energy Commission, Sacramento.

Higgins, K.F., C.D. Dieter, and R.E. Usgaard. 1995. Monitoring of seasonal bird activity and mortality on Unit 2 at the Buffalo Ridge Wind plant, Minnesota. Preliminary progress report for the research period May 1 - December 31, 1994. Prepared by the South Dakota Cooperative Fish and Wildlife Research Unit, National Biological Service, South Dakota State University.

Howell, J.A. and J. Noone. 1992. Examination of avian use and mortality at a U.S. Windpower wind energy development site, Montezuma Hills, Solano County, California. Final report. Prepared for Solano County Department of Environmental Management, Fairfield, California.

Howell, J.A. 1995. Avian mortality at rotor swept area equivalents. Altamont Pass and Montezuma Hills, California. Prepared for Kenetech Windpower [formerly U.S. Windpower, Inc.], San Francisco, California.

Howell, J. A. 1997. Bird mortality at rotor swept area equivalents, Altamont Pass and Montezuma Hills, California. Transactions of the Western Section of the Wildlife Society 33:24-29.

Hunt, G. 1994. A pilot golden eagle population project in the Altamont Pass Wind Resource Area, California. Prepared by The Predatory Bird Research Group, University of California, Santa Cruz, for The National Renewable Energy Laboratory, Golden, Colorado. 212 pp. 
Hunt, W.G., 2002. Golden eagles in a perilous landscape: predicting the effects of mitigation for energy-related mortality. Report to the California Energy Commission, PIER Grant No. 500-97-4033 to the University of California, Santa Cruz, CA.

Hurlbert, S.J. 1984. Pseudoreplication and the design of ecological field experiments. Ecological Monographs 54:187-211.

Johnson, G.D., W.P. Erickson, M.D. Strickland, M.F. Shepherd, and D.A. Shepherd. 1997. 1996 Avian Monitoring Studies, Buffalo Ridge Wind Resource Area, Minnesota. Technical Report prepared by WEST, Inc. for Northern States Power Co., Minneapolis, MN. 158pp.

Johnson, G.D., W.P. Erickson, M.D. Strickland, M.F. Shepherd, and D.A. Shepherd. 1998. Avian Monitoring Studies, Buffalo Ridge, Minnesota Wind Resource Area, 1996-1997. Technical Report prepared by WEST, Inc. for Northern States Power Co., Minneapolis, MN. 178pp.

Johnson, G.D., W.P. Erickson, M.D. Strickland, M.F. Shepherd, and D.A. Shepherd. 1999. Avian Monitoring Studies, Buffalo Ridge, Minnesota Wind Resource Area, 1996-1998. Technical Report prepared by WEST, Inc. for Northern States Power Co., Minneapolis, MN. 212pp.

Johnson, G.D., D.P. Young, Jr., W.P. Erickson, M.D. Strickland, R.E. Good and P. Becker. 2000a. Avian and bat mortality associated with the initial phase of the Foote Creek Rim Windpower Project, Carbon County, Wyoming: November 3, 1998 - October 31, 1999. Tech. Rept. prepared by WEST, Inc. for SeaWest Energy Corporation and Bureau of Land Management. 32pp.

Johnson, G.D., D.P. Young, Jr., C.E. Derby, W.P. Erickson, M.D. Strickland, and J.W. Kern. 2000b. Wildlife Monitoring Studies, SeaWest Windpower Plant, Carbon County, Wyoming, 1995-1999. Tech. Rept. prepared by WEST for SeaWest Energy Corporation and Bureau of Land Management. 195 pp.

Johnson, G.D., W.P. Erickson, M.D. Strickland, M.F. Shepherd, D.A. Shepherd, and S.A. Sarappo. 2002. Collision mortality of local and migrant birds at a large-scale wind power development on Buffalo Ridge, Minnesota. Wildlife Society Bulletin 30:879-887.

Johnson, G.D., W.P. Erickson, M.D. Strickland, M.F. Shepherd, D.A. Shepherd, and S.A. Sarappo. 2003. Mortality of bats at a large-scale wind power development at Buffalo Ridge, Minnesota. American Midland Naturalist in press.

Luke, A. and A. Watts. 1994. Bird deaths prompt rethink on wind farming in Spain. WindPower Monthly, February: 14-16. 
Martí, R. 1994. Bird/wind turbine investigations in southern Spain. Pages 48-52 in Proceedings of the national avian-wind power planning meeting, Denver, Colorado, 2021 July 1994. Proceedings prepared by LGL Ltd., environmental research associates, King City, Ontario, Canada. Author's address: Sociedad Española de Ornitologia, Ctra. de Húmera No. 63-1, 28224 Pozuelo, Madrid, Spain.

Morrison, M.L., W.M. Block, M.D. Strickland, and W.L. Kendall. 2001. Wildlife study design. Springer-Verlag New York, Inc., New York, NY. 210 pp.

Morrison, M. 2002. Searcher bias and scavenging rates in bird/wind energy studies. NREL/SR-500-30876.

Orloff, S. and A. Flannery. 1992. Wind turbine effects on avian activity, habitat use, and mortality in Altamont Pass and Solano County WRAs. Prepared by BioSystems Analysis, Inc., Tiburon, California, for California Energy Commission, Sacramento.

Orloff, S. and A. Flannery. 1996. A continued examination of avian mortality in the Altamont Pass Wind Resource Area. Final Report to the California Energy Commission by Biosystems Analysis, Inc., Tiburon, CA.

Osborn, R.G., K.F. Higgins, C.D. Dieter, and R.E. Usgaard. 1996. Bat collisions with wind turbines in southwestern Minnesota. Bat Research News 37:105-108.

Pain, D.J. 1991. Why are lead-poisoned waterfowl rarely seen? The disappearance of waterfowl carcasses in the Camargue, France. Wildfowl 42:118-122.

Pearson, D. 1992. Unpublished summary of Southern California Edison's 1985 bird monitoring studies in the San Gorgonio Pass and Coachella Valley. Presented at a joint Pacific Gas and Electric Company/California Energy Commission workshop on wind energy and avian mortality. San Ramon, CA.

Rugge, L. M. 2001. An avian risk behavior and mortality assessment at the Altamont Pass Wind Resource Area in Livermore, California. M.S. Thesis, California State University, Sacramento. $156 \mathrm{pp}$.

Sawyer, J.O. and T. Keeler-Wolf. 1995. A manual of California Vegetation. California Native Plant Society. Sacramento, CA.

Thelander, C.G. and L. Rugge. 2000. Bird risk behaviors and fatalities at the Altamont Wind Resource Area. Pp. 5-14 in Proceedings of the National Avian-Wind Power Planning Meeting III. National Wind Coordinating Committee/RESOLVE. Washington, D.C.

Thelander, C.G., S. Smallwood, and L. Rugge. 2003. Avian risk behavior and fatalities at the Altamont Wind Resource Area - March 1998 to December 2000. Progress Report to the National Renewable Energy Laboratory, Subcontract No. TAT-8-182209-01. K. Sinclair, Technical Monitor. 
U.S. Fish and Wildlife Service (USFWS). 2002. Birds of Conservation Concern 2002. Division of Migratory Bird Management, Arlington, VA. 99 pp. http://migratorybirds.fws.gov/reports/BCC2002.pdf

Weinberg, C. and R.H. Williams. 1990. Energy from the Sun. Scientific American. Sept.: 147-155.

Winkelman, J.E. 1985. Impact of medium-sized wind turbines on birds: a survey on flight behavior, victims, and disturbance. Netherlands Journal of Agricultural Science 33:75-78.

Winkelman, J.E. 1989. Birds at a windpark near Urk: bird collision victims and disturbance of wintering ducks, geese and swans. Rijksinstituut voor Natuurbeheer, Arnhem. RINRapport 89/15.

Winkelman, J.E. 1990. Disturbance of birds by the experimental wind park near Oosterbierum (Fr.) during building and partly operative situations [1984-1989]. RINreport 90/9, DLO-Institute for Forestry and Nature Research, Arnhem.

Winkelman, J. 1992a. The impact of the SEP wind park near Oosterbierum (Fr.), the Netherlands, on birds, 2: nocturnal collision risks (Dutch, English summary). RIN-report 92/3, DLO-Institute for Forestry and Nature Research, Arnhem.

Winkelman, J. 1992b. The impact of the SEP wind park near Oosterbierum (Fr.), the Netherlands, on birds, 4: Disturbance. RIN-report 92/5, DLO-Institute for Forestry and Nature Research, Arnhem.

Winkelman, J.E. 1994. Bird/wind turbine investigations in Europe. Pages 43-48 in Proceedings of the National Avian-Wind Power Planning Meeting, Denver Colorado, 2021 July 1994. Proceedings prepared by LGL Ltd., environmental research associates, King City, Ontario. Author's address: Birdlife/Vogelbescherming Nederland, Driebergweweg, The Netherlands.

Wobeser, G. and A.G. Wobeser. 1992. Carcass disappearance and estimation of mortality in a simulated die-off of small birds. Journal of Wildlife Diseases. 28:548-554.

Young, D.P., Jr., W.P. Erickson, R.E. Good, M.D. Strickland, and G.D. Johnson. 2003. Avian and bat mortality associated with the initial phase of the Foote Creek Rim wind power project, Carbon County, Wyoming: November 1998 - June 2002. Tech. Rept. prepared for SeaWest Energy Corporation and Bureau of Land Management. 
Table 1. Vegetation Types Documented during Phase I Studies at Tehachapi Pass Wind Resource Area, 2 October 1996 to 27 May 1998 (Based on Vegetation Observed Within $\mathbf{5 0 ~} \mathrm{m}$ of the Sample Site Center)

\begin{tabular}{ll}
\hline Vegetation Structure & Dominant Group/Species \\
\hline Grass & $\begin{array}{l}\text { California Annual Grassland } \\
\text { Desert Needlegrass }\end{array}$ \\
Sub-Shrub & Saltbush (Atriplex spp.) \\
& Brittlebush \\
& California Buckwheat \\
& Mormon Tea (Ephedra spp.) \\
& Interior Goldenbush \\
& Rabbit Brush \\
& \\
Large Shrub & California Juniper \\
& Joshua Tree \\
Wooded & Foothill Pine (pinyon, grey pine) \\
& Oak Woodland (scrub oak, canyon live \\
& oak) \\
& Other (described in comments) \\
\hline
\end{tabular}


Table 2. Description of Turbines within the Tehachapi Pass WRA and the Turbines Selected to Be Studied (Approximately $95 \%$ of the Turbines Within the WRA were Documented)

\begin{tabular}{|c|c|c|c|c|c|c|c|c|c|}
\hline Model & $\begin{array}{c}\text { Tower } \\
\text { Type }\end{array}$ & $\begin{array}{c}\text { Tower } \\
\text { Height }(\mathrm{m})\end{array}$ & $\begin{array}{c}\# \\
\text { blades }\end{array}$ & $\begin{array}{c}\text { Height } \\
\text { Swept } \\
\text { max }\end{array}$ & $\begin{array}{c}(\mathrm{m}) \text { of } \\
\text { Areas } \\
\text { min }\end{array}$ & $\begin{array}{c}\text { Rotor } \\
\text { /Blade } \\
\text { Length }(\mathrm{m})\end{array}$ & $\begin{array}{c}\mathrm{RSA}^{\mathrm{a}} \\
\mathrm{m}^{2}\end{array}$ & $\begin{array}{l}\text { \# in } \\
\text { WRA }\end{array}$ & $\begin{array}{c}\text { \# of } \\
\text { Sample } \\
\text { Sites }^{\text {b }}\end{array}$ \\
\hline \multicolumn{10}{|l|}{ West Ridge } \\
\hline Vesta V15 & SLT & 25.4 & 3 & 33.9 & 18.9 & 7.2 & 184 & 463 & 24 \\
\hline Vesta V17 & SLT & 14.7 & 3 & 24.2 & 7.2 & 8.2 & 227 & 639 & 29 \\
\hline Vesta V17E & SLT & 25.4 & 3 & 35.8 & 17 & 9.1 & 278 & 13 & 1 \\
\hline Vesta V27 & LLT & 28.4 & 3 & 41.3 & 14.3 & 12.8 & 573 & 87 & 24 \\
\hline \multirow{2}{*}{\multicolumn{9}{|c|}{ percentage of search area $=14 \%$}} & 78 \\
\hline & & & & & & & & & \\
\hline Cannon 250 & LTT & 42.7 & 3 & 62.2 & 23.2 & 19.5 & 1195 & 3 & 0 \\
\hline Micon 250 & LTT & 42.7 & 3 & 54.7 & 30.7 & 12 & 452 & 3 & 0 \\
\hline Vestas V39 & LTT & 42.7 & 3 & 62.2 & 23.2 & 19.5 & 1195 & 28 & 21 \\
\hline Micon 108 & STT & 24.4 & 3 & 33.4 & 15.4 & 8.5 & 283 & 141 & 7 \\
\hline Nordtank 150 & STT & 25.9 & 3 & 35.4 & 16.4 & 9 & 254 & 102 & 3 \\
\hline Nordtank 65-75 & STT & 24.4 & 3 & 32.7 & 16.1 & 8.3 & 216 & 388 & 13 \\
\hline EHD Prototype & VAT & 57.6 & 3 & $\mathrm{nc}$ & $\mathrm{nc}$ & nc & $\mathrm{nc}$ & 1 & 0 \\
\hline FloWind 17 & VAT & 28.1 & 2 & nc & nc & nc & nc & 161 & 10 \\
\hline FloWind 19 & VAT & 30.8 & 2 & nc & nc & nc & nc & 176 & 20 \\
\hline \multicolumn{9}{|c|}{ percentage of search area $=14 \%$} & 74 \\
\hline Danwind 160 & STT & 32 & 3 & 43 & 21 & 11 & 415 & 91 & 0 \\
\hline Micon 108 & STT & 23.8 & 3 & 33.3 & 14.3 & 9 & 254 & 251 & 15 \\
\hline $\begin{array}{l}\text { Mitsubishi } \\
250 \mathrm{~A}\end{array}$ & LTT & 26 & 3 & 38 & 14 & 12 & 531 & 20 & 0 \\
\hline $\begin{array}{l}\text { Mitsubishi } \\
\text { 250B }\end{array}$ & LTT & 32 & 3 & 45 & 19 & 13 & 616 & 340 & 14 \\
\hline $\begin{array}{l}\text { Mitsubishi } \\
250 \mathrm{C}\end{array}$ & LTT & 32 & 3 & 45 & 19 & 13 & 616 & 300 & 16 \\
\hline Nordtank 150 & STT & 26 & 3 & 36 & 16 & 10 & 346 & 62 & 4 \\
\hline \multicolumn{7}{|c|}{ percentage of search area $=14 \%$} & subtotal & 1064 & 49 \\
\hline \multicolumn{7}{|c|}{ percentage of search area $=14 \%$} & Total & 3269 & 201 \\
\hline
\end{tabular}

${ }^{a}$ Rotor swept area

${ }^{\mathrm{b}}$ All sample sites included multiple turbines. 
Table 3. Sample Sizes for Each Factor Used in Comparison of Fatality Rates, Use, and Collision Risk

\begin{tabular}{|c|c|c|c|c|c|c|c|c|}
\hline \multirow{2}{*}{ Measure/Category } & \multicolumn{2}{|c|}{ Overall } & \multicolumn{2}{|c|}{ West Ridge } & \multicolumn{2}{|c|}{ Middle Ridge } & \multicolumn{2}{|c|}{ East Slope } \\
\hline & $\mathbf{n}$ & $\%$ & $\mathbf{n}$ & $\%$ & $\mathbf{n}$ & $\%$ & $\mathbf{n}$ & $\%$ \\
\hline \multicolumn{9}{|l|}{ Geographic } \\
\hline \multicolumn{9}{|l|}{ Turbine Type } \\
\hline LLT & 45 & 22.4 & 24 & 30.8 & 21 & 28.4 & 0 & 0.0 \\
\hline slt & 28 & 13.9 & 28 & 35.9 & 0 & 0.0 & 0 & 0.0 \\
\hline LTT & 30 & 14.9 & 0 & 0.0 & 0 & 0.0 & 30 & 61.2 \\
\hline stt & 42 & 20.9 & 0 & 0.0 & 23 & 31.1 & 19 & 38.8 \\
\hline VAT & 30 & 14.9 & 0 & 0.0 & 30 & 40.5 & 0 & 0.0 \\
\hline ww & 26 & 12.9 & 26 & 33.3 & 0 & 0.0 & 0 & 0.0 \\
\hline \multicolumn{9}{|l|}{ Turbine Size } \\
\hline Large & 75 & 37.3 & 24 & 30.8 & 21 & 28.4 & 30 & 61.2 \\
\hline Small & 70 & 34.8 & 28 & 35.9 & 23 & 31.1 & 19 & 38.8 \\
\hline \multicolumn{9}{|l|}{ Turbine Style } \\
\hline Lattice & 73 & 36.3 & 52 & 66.7 & 21 & 28.4 & 0 & 0.0 \\
\hline Tubular & 72 & 35.8 & 0 & 0.0 & 23 & 31.1 & 49 & 100.0 \\
\hline \multicolumn{9}{|l|}{ Row Position } \\
\hline End-row & 41 & 20.4 & 21 & 26.9 & 10 & 13.5 & 10 & 20.4 \\
\hline Mid-row & 116 & 57.7 & 55 & 70.5 & 22 & 29.7 & 39 & 79.6 \\
\hline Discontinuous & 14 & 7.0 & 2 & 2.6 & 12 & 16.2 & 0 & 0.0 \\
\hline Not Applicable (VAT) & 30 & 14.9 & 0 & 0.0 & 30 & 40.5 & 0 & 0.0 \\
\hline \multicolumn{9}{|l|}{ Density } \\
\hline One & 37 & 18.4 & 2 & 2.6 & 34 & 45.9 & 1 & 2.0 \\
\hline Low & 120 & 59.7 & 41 & 52.6 & 31 & 41.9 & 48 & 98.0 \\
\hline Medium & 26 & 12.9 & 17 & 21.8 & 9 & 12.2 & 0 & 0.0 \\
\hline High & 18 & 9.0 & 18 & 23.1 & 0 & 0.0 & 0 & 0.0 \\
\hline \multicolumn{9}{|l|}{ Rotor Swept Area } \\
\hline 177 & 24 & 11.9 & 24 & 30.8 & 0 & 0.0 & 0 & 0.0 \\
\hline 216 & 13 & 6.5 & 0 & 0.0 & 13 & 17.6 & 0 & 0.0 \\
\hline 227 & 29 & 14.4 & 29 & 37.2 & 0 & 0.0 & 0 & 0.0 \\
\hline 278 & 1 & 0.5 & 1 & 1.3 & 0 & 0.0 & 0 & 0.0 \\
\hline 284 & 25 & 12.4 & 0 & 0.0 & 10 & 13.5 & 15 & 30.6 \\
\hline 346 & 4 & 2.0 & 0 & 0.0 & 0 & 0.0 & 4 & 8.2 \\
\hline 573 & 24 & 11.9 & 24 & 30.8 & 0 & 0.0 & 0 & 0.0 \\
\hline 616 & 30 & 14.9 & 0 & 0.0 & 0 & 0.0 & 30 & 61.2 \\
\hline 1066 & 10 & 5.0 & 0 & 0.0 & 10 & 13.5 & 0 & 0.0 \\
\hline 1195 & 21 & 10.4 & 0 & 0.0 & 21 & 28.4 & 0 & 0.0 \\
\hline 1281 & 20 & 10.0 & 0 & 0.0 & 20 & 27.0 & 0 & 0.0 \\
\hline
\end{tabular}


Table 4. Number of Groups and Individuals of Avian Groups Observed during Bird Utilization Surveys at Tehachapi Pass Wind Resource Area, 2 October 1996 to 27 May 1998

\begin{tabular}{|c|c|c|c|c|}
\hline Species & $\begin{array}{c}\# \\
\text { Groups }\end{array}$ & $\begin{array}{c}\# \\
\text { Det. }\end{array}$ & $\begin{array}{c}\% \text { Group } \\
\text { Composition }\end{array}$ & $\begin{array}{c}\% \text { Overall } \\
\text { Composition }\end{array}$ \\
\hline \multicolumn{5}{|l|}{ Raptors } \\
\hline Red-Tailed Hawk & 106 & 119 & 60.10 & 1.87 \\
\hline Unidentified Raptor & 30 & 32 & 16.16 & 0.50 \\
\hline American Kestrel & 29 & 30 & 15.15 & 0.47 \\
\hline Unidentified Buteo & 5 & 5 & 2.53 & 0.08 \\
\hline Golden Eagle & 2 & 3 & 1.52 & 0.05 \\
\hline Northern Harrier & 2 & 2 & 1.01 & 0.03 \\
\hline Sharp-Shinned Hawk & 2 & 2 & 1.01 & 0.03 \\
\hline Unidentified Falcon & 2 & 2 & 1.01 & 0.03 \\
\hline Ferruginous Hawk & 1 & 1 & 0.51 & 0.02 \\
\hline Prairie Falcon & 1 & 1 & 0.51 & 0.02 \\
\hline Unidentified Accipiter & 1 & 1 & 0.51 & 0.02 \\
\hline Subtotal & 181 & 198 & 100.00 & 3.10 \\
\hline \multicolumn{5}{|l|}{ Corvids } \\
\hline Common Raven & 1067 & 1702 & 87.33 & 26.68 \\
\hline Scrub Jay & 161 & 197 & 10.11 & 3.09 \\
\hline Common Raven/American Crow & 27 & 50 & 2.57 & 0.78 \\
\hline Subtotal & 1255 & 1949 & 100.00 & 30.55 \\
\hline \multicolumn{5}{|l|}{ Passerines } \\
\hline Horned Lark & 171 & 819 & 25.88 & 12.84 \\
\hline Unidentified Passerine & 340 & 773 & 24.42 & 12.12 \\
\hline Western Meadowlark & 233 & 427 & 13.49 & 6.69 \\
\hline European Starling & 106 & 264 & 8.34 & 4.14 \\
\hline Dark-Eyed Junco & 52 & 212 & 6.70 & 3.32 \\
\hline White-Crowned Sparrow & 27 & 146 & 4.61 & 2.29 \\
\hline Brewer's Blackbird & 9 & 132 & 4.17 & 2.07 \\
\hline Loggerhead Shrike & 84 & 88 & 2.78 & 1.38 \\
\hline Unidentified Swallow & 3 & 63 & 1.99 & 0.99 \\
\hline Unidentified Swift & 1 & 50 & 1.58 & 0.78 \\
\hline Unidentified Sparrow & 14 & 35 & 1.11 & 0.55 \\
\hline House Finch & 11 & 34 & 1.07 & 0.53 \\
\hline Plain Titmouse & 22 & 26 & 0.82 & 0.41 \\
\hline Cactus Wren & 22 & 23 & 0.73 & 0.36 \\
\hline California Towhee & 10 & 13 & 0.41 & 0.20 \\
\hline
\end{tabular}


Table 4. (continued)

\begin{tabular}{|c|c|c|c|c|}
\hline Species & $\begin{array}{c}\# \\
\text { Groups }\end{array}$ & $\begin{array}{c}\text { \# } \\
\text { Det. }\end{array}$ & $\begin{array}{c}\% \text { Group } \\
\text { Composition }\end{array}$ & $\begin{array}{c}\% \text { Overall } \\
\text { Composition }\end{array}$ \\
\hline Lark Sparrow & 8 & 10 & 0.32 & 0.16 \\
\hline Yellow-Rumped Warbler & 5 & 9 & 0.28 & 0.14 \\
\hline Rock Wren & 6 & 6 & 0.19 & 0.09 \\
\hline Western Bluebird & 4 & 6 & 0.19 & 0.09 \\
\hline Western Kingbird & 2 & 3 & 0.09 & 0.05 \\
\hline House/Purple Finch & 2 & 3 & 0.09 & 0.05 \\
\hline Sage Sparrow & 3 & 3 & 0.09 & 0.05 \\
\hline Cliff Swallow & 1 & 3 & 0.09 & 0.05 \\
\hline Unidentified Wren & 3 & 3 & 0.09 & 0.05 \\
\hline American Robin & 2 & 3 & 0.09 & 0.05 \\
\hline Unidentified Finch & 2 & 2 & 0.06 & 0.03 \\
\hline Rufous-Crowned Sparrow & 1 & 2 & 0.06 & 0.03 \\
\hline Northern Mockingbird & 2 & 2 & 0.06 & 0.03 \\
\hline Unidentified Hummingbird & 2 & 2 & 0.06 & 0.03 \\
\hline Black-Throated Sparrow & 1 & 1 & 0.03 & 0.02 \\
\hline Yellow-Breasted Chat & 1 & 1 & 0.03 & 0.02 \\
\hline Bewick's Wren & 1 & 1 & 0.03 & 0.02 \\
\hline Subtotal & 1151 & 3165 & 100.00 & 49.61 \\
\hline \multicolumn{5}{|l|}{ Other } \\
\hline Unidentified Bird & 243 & 578 & 54.12 & 9.06 \\
\hline Turkey Vulture & 19 & 404 & 37.83 & 6.33 \\
\hline California Quail & 8 & 43 & 4.03 & 0.67 \\
\hline Rock Dove & 7 & 23 & 2.15 & 0.36 \\
\hline Greater Roadrunner & 7 & 7 & 0.66 & 0.11 \\
\hline Chukar & 3 & 4 & 0.37 & 0.06 \\
\hline Mourning Dove & 1 & 2 & 0.19 & 0.03 \\
\hline Unidentified Duck & 1 & 1 & 0.09 & 0.02 \\
\hline Band-Tailed Pigeon & 1 & 1 & 0.09 & 0.02 \\
\hline Downy Woodpecker & 1 & 1 & 0.09 & 0.02 \\
\hline Ladder-Backed Woodpecker & 1 & 1 & 0.09 & 0.02 \\
\hline Nuttall's Woodpecker & 1 & 1 & 0.09 & 0.02 \\
\hline Red-Shafted Flicker & 1 & 1 & 0.09 & 0.02 \\
\hline Unidentified Woodpecker & 1 & 1 & 0.09 & 0.02 \\
\hline Subtotal & 295 & 1068 & 100.00 & 16.74 \\
\hline Total & 2882 & 6380 & 100.00 & 100.00 \\
\hline
\end{tabular}


Table 5. Avian Abundance and Richness by Season during Phase I Utilization Surveys at Tehachapi Pass Wind Resource Area, 2 October 1996 to 27 May 1998. (Calculated Based on Observations within $200 \mathrm{~m}$ of Site Center)

\begin{tabular}{|c|c|c|c|c|}
\hline \multirow[b]{2}{*}{ Season } & \multicolumn{4}{|c|}{ Study Area } \\
\hline & Overall & West Ridge & Middle Ridge & East Slope \\
\hline \multicolumn{5}{|l|}{ Spring } \\
\hline No. Species & 25 & 13 & 14 & 10 \\
\hline Mean No. / Survey ${ }^{\mathrm{a}}$ & 1.61 & 2.36 & 0.95 & 1.32 \\
\hline Mean No. Species / Survey & 1.26 & 1.17 & 1.24 & 1.38 \\
\hline \multicolumn{5}{|l|}{ Summer } \\
\hline No. Species & 28 & 17 & 20 & 11 \\
\hline Mean No. / Survey ${ }^{a}$ & 0.93 & 1.46 & 0.72 & 0.35 \\
\hline Mean No. Species / Survey & 1.20 & 1.23 & 1.23 & 1.04 \\
\hline \multicolumn{5}{|l|}{ Fall } \\
\hline No. Species & 25 & 16 & 16 & 13 \\
\hline Mean No. / Survey ${ }^{\mathrm{a}}$ & 1.55 & 1.61 & 1.25 & 1.77 \\
\hline Mean No. Species / Survey & 1.25 & 1.29 & 1.21 & 1.19 \\
\hline \multicolumn{5}{|l|}{ Winter } \\
\hline No. Species & 20 & 15 & 8 & 8 \\
\hline Mean No. / Survey ${ }^{a}$ & 1.20 & 1.75 & 0.44 & 1.09 \\
\hline Mean No. Species / Survey & 1.16 & 1.12 & 1.08 & 1.29 \\
\hline
\end{tabular}


Table 6. Mean Abundance, Percent Composition, and Percent Frequency of Occurrence of Avian Groups Observed during Phase I Utilization Surveys at Tehachapi Pass Wind Resource Area, 2 October 1996 to 27 May 1998 (Calculated Based on Observations within $200 \mathrm{~m}$ of Site Center)

\begin{tabular}{|c|c|c|c|c|c|c|c|c|c|c|c|c|}
\hline \multirow[t]{2}{*}{ Group } & \multicolumn{4}{|c|}{ Mean Abundance } & \multicolumn{4}{|c|}{$\%$ Composition } & \multicolumn{4}{|c|}{$\begin{array}{l}\% \text { Frequency of } \\
\text { Occurrence }\end{array}$} \\
\hline & Spr & Sum & Fall & Win & Spr & Sum & Fall & Win & Spr & Sum & Fall & Win \\
\hline \multicolumn{13}{|l|}{ Overall } \\
\hline Raptors & 0.02 & 0.02 & 0.04 & 0.03 & 1.0 & 2.4 & 2.5 & 2.7 & 1.6 & 2.0 & 3.5 & 2.2 \\
\hline Corvids & 0.49 & 0.27 & 0.26 & 0.33 & 30.3 & 28.6 & 17.0 & 27.4 & 20.8 & 14.9 & 16.5 & 17.4 \\
\hline Passerines & 0.86 & 0.59 & 1.14 & 0.79 & 53.5 & 63.1 & 73.8 & 65.6 & 31.2 & 21.6 & 22.2 & 17.0 \\
\hline Other & 0.24 & 0.05 & 0.10 & 0.05 & 15.2 & 5.9 & 6.7 & 4.3 & 2.7 & 3.6 & 3.4 & 1.7 \\
\hline Total & 1.61 & 0.93 & 1.55 & 1.20 & 100 & 100 & 100 & 100 & & & & \\
\hline \multicolumn{13}{|l|}{ West Ridge } \\
\hline Raptors & 0.02 & 0.04 & 0.04 & 0.05 & 0.9 & 2.4 & 2.7 & 2.9 & 2.1 & 2.9 & 3.9 & 3.3 \\
\hline Corvids & 0.82 & 0.47 & 0.45 & 0.48 & 34.7 & 32.5 & 27.9 & 27.4 & 31.1 & 25.3 & 27.1 & 23.2 \\
\hline Passerines & 0.94 & 0.88 & 1.00 & 1.15 & 39.6 & 60.3 & 62.4 & 65.7 & 21.1 & 22.5 & 20.4 & 14.7 \\
\hline Other & 0.58 & 0.07 & 0.11 & 0.07 & 24.7 & 4.8 & 6.9 & 4.0 & 2.6 & 3.7 & 3.9 & 2.2 \\
\hline Total & 2.36 & 1.46 & 1.61 & 1.75 & 100 & 100 & 100 & 100 & & & & \\
\hline \multicolumn{13}{|l|}{ Middle Ridge } \\
\hline Raptors & 0.01 & 0.02 & 0.05 & 0.03 & 0.7 & 3.1 & 3.9 & 6.6 & 0.7 & 2.2 & 4.6 & 2.3 \\
\hline Corvids & 0.24 & 0.16 & 0.22 & 0.23 & 25.2 & 23.0 & 17.8 & 52.6 & 10.0 & 9.9 & 14.4 & 13.4 \\
\hline Passerines & 0.68 & 0.46 & 0.84 & 0.17 & 71.3 & 64.8 & 67.2 & 39.5 & 28.7 & 25.0 & 19.9 & 8.7 \\
\hline Other & 0.03 & 0.07 & 0.14 & 0.01 & 2.8 & 9.2 & 11.0 & 1.3 & 2.0 & 4.9 & 3.6 & 0.6 \\
\hline Total & 0.95 & 0.72 & 1.25 & 0.44 & 100 & 100 & 100 & 100 & & & & \\
\hline \multicolumn{13}{|l|}{ East Slope } \\
\hline Raptors & 0.02 & $<0.01$ & 0.02 & 0 & 1.5 & 0.9 & 1.1 & 0 & 2.0 & 0.3 & 2.0 & 0 \\
\hline Corvids & 0.31 & 0.06 & 0.04 & 0.16 & 23.7 & 16.4 & 2.4 & 14.7 & 18.7 & 4.3 & 3.6 & 10.9 \\
\hline Passerines & 0.95 & 0.27 & 1.65 & 0.86 & 72.2 & 77.6 & 93.2 & 78.7 & 46.7 & 16.5 & 27.1 & 31.9 \\
\hline Other & 0.03 & 0.02 & 0.06 & 0.07 & 2.5 & 5.2 & 3.3 & 6.7 & 3.3 & 1.8 & 2.3 & 2.2 \\
\hline Total & 1.32 & 0.35 & 1.77 & 1.09 & 100 & 100 & 100 & 100 & & & & \\
\hline
\end{tabular}


Table 7. Five Most Abundant Avian Species (Based on Mean Number per Five-Minute Utilization Survey) Observed during Phase I Utilization Surveys at Tehachapi Pass Wind Resource Area, 2 October 1996 to 27 May 1998 (Calculated Based on Observations within $200 \mathrm{~m}$ of Site Center)

\begin{tabular}{|c|c|c|c|c|c|c|c|}
\hline \multicolumn{4}{|l|}{ Study Area } & \multicolumn{4}{|l|}{ Season } \\
\hline \multicolumn{2}{|l|}{ Spring } & \multicolumn{2}{|l|}{ Summer } & \multicolumn{2}{|l|}{ Fall } & \multicolumn{2}{|c|}{ Winter } \\
\hline Species & Use & Species & Use & Species & Use & Species & Use \\
\hline \multicolumn{8}{|l|}{ Overall } \\
\hline $\begin{array}{l}\text { Common } \\
\text { Raven }\end{array}$ & 0.44 & Common Raven & 0.23 & Horned Lark & 0.41 & $\begin{array}{l}\text { Common } \\
\text { Raven }\end{array}$ & 0.32 \\
\hline $\begin{array}{l}\text { European } \\
\text { Starling }\end{array}$ & 0.23 & Horned Lark & 0.19 & Common Raven & 0.22 & $\begin{array}{l}\text { European } \\
\text { Starling }\end{array}$ & 0.19 \\
\hline $\begin{array}{l}\text { Unidentified } \\
\text { Swallow }\end{array}$ & 0.12 & $\begin{array}{l}\text { Brewer's } \\
\text { Blackbird }\end{array}$ & 0.10 & Dark-Eyed Junco & 0.14 & $\begin{array}{l}\text { Western } \\
\text { Meadowlark }\end{array}$ & 0.16 \\
\hline $\begin{array}{l}\text { Western } \\
\text { Meadowlark }\end{array}$ & 0.11 & $\begin{array}{l}\text { Western } \\
\text { Meadowlark }\end{array}$ & 0.05 & $\begin{array}{l}\text { Western } \\
\text { Meadowlark }\end{array}$ & 0.14 & $\begin{array}{l}\text { Unidentified } \\
\text { Swift }\end{array}$ & 0.09 \\
\hline Horned Lark & 0.06 & Scrub Jay & 0.04 & $\begin{array}{l}\text { White-Crowned } \\
\text { Sparrow }\end{array}$ & 0.12 & $\begin{array}{l}\text { Dark-Eyed } \\
\text { Junco }\end{array}$ & 0.08 \\
\hline \multicolumn{8}{|l|}{ West Ridge } \\
\hline $\begin{array}{l}\text { Common } \\
\text { Raven }\end{array}$ & 0.72 & Common Raven & 0.38 & Common Raven & 0.37 & $\begin{array}{l}\text { Common } \\
\text { Raven }\end{array}$ & 0.47 \\
\hline $\begin{array}{l}\text { Unidentified } \\
\text { Swallow }\end{array}$ & 0.32 & Horned Lark & 0.30 & Dark-Eyed Junco & 0.22 & $\begin{array}{l}\text { European } \\
\text { Starling }\end{array}$ & 0.28 \\
\hline Scrub Jay & 0.11 & $\begin{array}{l}\text { Brewer's } \\
\text { Blackbird }\end{array}$ & 0.22 & $\begin{array}{l}\text { Western } \\
\text { Meadowlark }\end{array}$ & 0.21 & $\begin{array}{l}\text { Western } \\
\text { Meadowlark }\end{array}$ & 0.21 \\
\hline $\begin{array}{l}\text { Western } \\
\text { Meadowlark }\end{array}$ & 0.06 & Scrub Jay & 0.09 & Horned Lark & 0.16 & $\begin{array}{l}\text { Unidentified } \\
\text { Swift }\end{array}$ & 0.18 \\
\hline $\begin{array}{l}\text { European } \\
\text { Starling }\end{array}$ & 0.05 & $\begin{array}{l}\text { Western } \\
\text { Meadowlark }\end{array}$ & 0.05 & Scrub Jay & 0.07 & $\begin{array}{l}\text { Dark-Eyed } \\
\text { Junco }\end{array}$ & 0.14 \\
\hline \multicolumn{8}{|l|}{ Middle Ridge } \\
\hline $\begin{array}{l}\text { European } \\
\text { Starling }\end{array}$ & 0.24 & Common Raven & 0.16 & $\begin{array}{l}\text { White-Crowned } \\
\text { Sparrow }\end{array}$ & 0.29 & $\begin{array}{l}\text { Common } \\
\text { Raven }\end{array}$ & 0.23 \\
\hline $\begin{array}{l}\text { Common } \\
\text { Raven }\end{array}$ & 0.24 & Horned Lark & 0.16 & Common Raven & 0.21 & $\begin{array}{l}\text { Loggerhead } \\
\text { Shrike }\end{array}$ & 0.08 \\
\hline Horned Lark & 0.09 & $\begin{array}{l}\text { Loggerhead } \\
\text { Shrike }\end{array}$ & 0.05 & Horned Lark & 0.18 & $\begin{array}{l}\text { Dark-Eyed } \\
\text { Junco }\end{array}$ & 0.06 \\
\hline $\begin{array}{l}\text { Dark-Eyed } \\
\text { Junco }\end{array}$ & 0.05 & $\begin{array}{l}\text { Western } \\
\text { Meadowlark }\end{array}$ & 0.05 & $\begin{array}{l}\text { Western } \\
\text { Meadowlark }\end{array}$ & 0.08 & $\begin{array}{l}\text { Red-Tailed } \\
\text { Hawk }\end{array}$ & 0.02 \\
\hline Lark Sparrow & 0.05 & $\begin{array}{l}\text { European } \\
\text { Starling }\end{array}$ & 0.03 & California Quail & 0.07 & $\begin{array}{l}\text { American } \\
\text { Kestrel }\end{array}$ & 0.01 \\
\hline $\begin{array}{l}\text { Western } \\
\text { Meadowlark }\end{array}$ & 0.05 & & & & & & \\
\hline
\end{tabular}


Table 7. (continued)

\begin{tabular}{|c|c|c|c|c|c|c|c|}
\hline \multicolumn{4}{|l|}{ Study Area } & \multicolumn{4}{|l|}{ Season } \\
\hline \multicolumn{2}{|l|}{ Spring } & \multicolumn{2}{|l|}{ Summer } & \multicolumn{2}{|l|}{ Fall } & \multicolumn{2}{|c|}{ Winter } \\
\hline Species & Use & Species & Use & Species & Use & Species & Use \\
\hline \multicolumn{8}{|l|}{ East Slope } \\
\hline $\begin{array}{l}\text { European } \\
\text { Starling }\end{array}$ & 0.43 & Common Raven & 0.06 & Horned Lark & 1.00 & $\begin{array}{l}\text { Western } \\
\text { Meadowlark }\end{array}$ & 0.28 \\
\hline $\begin{array}{l}\text { Common } \\
\text { Raven }\end{array}$ & 0.29 & Horned Lark & 0.06 & $\begin{array}{l}\text { Dark-Eyed } \\
\text { Junco }\end{array}$ & 0.14 & $\begin{array}{l}\text { European } \\
\text { Starling }\end{array}$ & 0.23 \\
\hline $\begin{array}{l}\text { Western } \\
\text { Meadowlark }\end{array}$ & 0.22 & $\begin{array}{l}\text { Western } \\
\text { Meadowlark }\end{array}$ & 0.05 & $\begin{array}{l}\text { Western } \\
\text { Meadowlark }\end{array}$ & 0.09 & $\begin{array}{l}\text { Common } \\
\text { Raven }\end{array}$ & 0.16 \\
\hline Horned Lark & 0.10 & $\begin{array}{l}\text { European } \\
\text { Starling }\end{array}$ & 0.03 & $\begin{array}{l}\text { White-Crowned } \\
\text { Sparrow }\end{array}$ & 0.06 & Horned Lark & 0.14 \\
\hline $\begin{array}{l}\text { Loggerhead } \\
\text { Shrike }\end{array}$ & 0.06 & Cactus Wren & 0.03 & $\begin{array}{l}\text { Common } \\
\text { Raven }\end{array}$ & 0.04 & $\begin{array}{l}\text { White- } \\
\text { Crowned } \\
\text { Sparrow }\end{array}$ & 0.06 \\
\hline
\end{tabular}


Table 8. Five Most Frequently Occurring Avian Species during Phase I Utilization Surveys at Tehachapi Pass Wind Resource Area, 2 October 1996 to 27 May 1998 (Calculated Based on Observations within $200 \mathrm{~m}$ of Site Center)

\begin{tabular}{|c|c|c|c|c|c|c|c|}
\hline \multicolumn{4}{|l|}{ Study Area } & \multicolumn{4}{|l|}{ Season } \\
\hline \multicolumn{2}{|c|}{ Spring } & \multicolumn{2}{|c|}{ Summer } & \multicolumn{2}{|l|}{ Fall } & \multicolumn{2}{|l|}{ Winter } \\
\hline Species & $\%$ & Species & $\%$ & Species & $\%$ & Species & $\%$ \\
\hline \multicolumn{8}{|l|}{ Overall } \\
\hline $\begin{array}{l}\text { Common } \\
\text { Raven }\end{array}$ & 19.0 & $\begin{array}{l}\text { Common } \\
\text { Raven }\end{array}$ & 12.1 & $\begin{array}{l}\text { Common } \\
\text { Raven }\end{array}$ & 13.4 & $\begin{array}{l}\text { Common } \\
\text { Raven }\end{array}$ & 16.7 \\
\hline $\begin{array}{l}\text { Western } \\
\text { Meadowlark }\end{array}$ & 8.6 & Horned Lark & 4.2 & $\begin{array}{l}\text { Western } \\
\text { Meadowlark }\end{array}$ & 4.0 & $\begin{array}{l}\text { Western } \\
\text { Meadowlark }\end{array}$ & 3.8 \\
\hline $\begin{array}{l}\text { European } \\
\text { Starling }\end{array}$ & 6.7 & $\begin{array}{l}\text { Western } \\
\text { Meadowlark }\end{array}$ & 3.4 & $\begin{array}{l}\text { Dark-Eyed } \\
\text { Junco }\end{array}$ & 2.5 & $\begin{array}{l}\text { Loggerhead } \\
\text { Shrike }\end{array}$ & 2.9 \\
\hline $\begin{array}{l}\text { Loggerhead } \\
\text { Shrike }\end{array}$ & 3.3 & Scrub Jay & 2.7 & Scrub Jay & 2.5 & $\begin{array}{l}\text { European } \\
\text { Starling }\end{array}$ & 2.7 \\
\hline Horned Lark & 2.7 & $\begin{array}{l}\text { Loggerhead } \\
\text { Shrike }\end{array}$ & 2.4 & Horned Lark & 2.4 & $\begin{array}{l}\text { Red-Tailed } \\
\text { Hawk }\end{array}$ & 1.2 \\
\hline \multicolumn{8}{|l|}{ West Ridge } \\
\hline $\begin{array}{l}\text { Common } \\
\text { Raven }\end{array}$ & 27.9 & $\begin{array}{l}\text { Common } \\
\text { Raven }\end{array}$ & 18.8 & $\begin{array}{l}\text { Common } \\
\text { Raven }\end{array}$ & 21.1 & $\begin{array}{l}\text { Common } \\
\text { Raven }\end{array}$ & 22.1 \\
\hline $\begin{array}{l}\text { Western } \\
\text { Meadowlark }\end{array}$ & 6.3 & Scrub Jay & 6.3 & Scrub Jay & 5.6 & $\begin{array}{l}\text { Western } \\
\text { Meadowlark }\end{array}$ & 3.7 \\
\hline Scrub Jay & 3.2 & Horned Lark & 5.7 & $\begin{array}{l}\text { Western } \\
\text { Meadowlark }\end{array}$ & 4.4 & $\begin{array}{l}\text { Dark-Eyed } \\
\text { Junco }\end{array}$ & 1.8 \\
\hline $\begin{array}{l}\text { European } \\
\text { Starling }\end{array}$ & 2.6 & $\begin{array}{l}\text { Western } \\
\text { Meadowlark }\end{array}$ & 3.1 & $\begin{array}{l}\text { Dark-Eyed } \\
\text { Junco }\end{array}$ & 3.5 & Plain Titmouse & 1.8 \\
\hline $\begin{array}{l}\text { Red-Tailed } \\
\text { Hawk }\end{array}$ & 2.1 & $\begin{array}{l}\text { European } \\
\text { Starling }\end{array}$ & 1.4 & $\begin{array}{l}\text { Red-Tailed } \\
\text { Hawk }\end{array}$ & 2.1 & $\begin{array}{l}\text { Red-Tailed } \\
\text { Hawk }\end{array}$ & 1.8 \\
\hline \multicolumn{8}{|l|}{ Middle Ridge } \\
\hline $\begin{array}{l}\text { Common } \\
\text { Raven }\end{array}$ & 10.0 & $\begin{array}{l}\text { Common } \\
\text { Raven }\end{array}$ & 9.6 & $\begin{array}{l}\text { Common } \\
\text { Raven }\end{array}$ & 13.1 & $\begin{array}{l}\text { Common } \\
\text { Raven }\end{array}$ & 12.8 \\
\hline $\begin{array}{l}\text { Western } \\
\text { Meadowlark }\end{array}$ & 5.3 & $\begin{array}{l}\text { Loggerhead } \\
\text { Shrike }\end{array}$ & 4.7 & $\begin{array}{l}\text { Western } \\
\text { Meadowlark }\end{array}$ & 3.9 & $\begin{array}{l}\text { Loggerhead } \\
\text { Shrike }\end{array}$ & 5.8 \\
\hline $\begin{array}{l}\text { Loggerhead } \\
\text { Shrike }\end{array}$ & 4.7 & $\begin{array}{l}\text { Western } \\
\text { Meadowlark }\end{array}$ & 4.1 & $\begin{array}{l}\text { Red-Tailed } \\
\text { Hawk }\end{array}$ & 3.3 & $\begin{array}{l}\text { Red-Tailed } \\
\text { Hawk }\end{array}$ & 1.2 \\
\hline $\begin{array}{l}\text { European } \\
\text { Starling }\end{array}$ & 4.0 & Horned Lark & 3.3 & Horned Lark & 2.6 & $\begin{array}{l}\text { American } \\
\text { Kestrel }\end{array}$ & 1.2 \\
\hline Horned Lark & 3.3 & $\begin{array}{l}\text { European } \\
\text { Starling }\end{array}$ & 1.6 & $\begin{array}{l}\text { Loggerhead } \\
\text { Shrike }\end{array}$ & 2.0 & $\begin{array}{l}\text { Greater } \\
\text { Roadrunner }\end{array}$ & 0.6 \\
\hline
\end{tabular}


Table 8. (Continued)

\begin{tabular}{|c|c|c|c|c|c|c|c|}
\hline \multicolumn{4}{|l|}{ Study Area } & \multicolumn{4}{|l|}{ Season } \\
\hline \multicolumn{2}{|c|}{ Spring } & \multicolumn{2}{|c|}{ Summer } & \multicolumn{2}{|l|}{ Fall } & \multicolumn{2}{|c|}{ Winter } \\
\hline Species & $\%$ & Species & $\%$ & Species & $\%$ & Species & $\%$ \\
\hline \multicolumn{8}{|l|}{ East Slope } \\
\hline $\begin{array}{l}\text { Common } \\
\text { Raven }\end{array}$ & 16.7 & $\begin{array}{l}\text { Common } \\
\text { Raven }\end{array}$ & 4.3 & Horned Lark & 3.6 & $\begin{array}{l}\text { Common } \\
\text { Raven }\end{array}$ & 10.9 \\
\hline $\begin{array}{l}\text { European } \\
\text { Starling }\end{array}$ & 14.7 & $\begin{array}{l}\text { Western } \\
\text { Meadowlark }\end{array}$ & 3.0 & $\begin{array}{l}\text { Western } \\
\text { Meadowlark }\end{array}$ & 3.6 & $\begin{array}{l}\text { European } \\
\text { Starling }\end{array}$ & 8.7 \\
\hline $\begin{array}{l}\text { Western } \\
\text { Meadowlark }\end{array}$ & 14.7 & Cactus Wren & 2.7 & $\begin{array}{l}\text { Common } \\
\text { Raven }\end{array}$ & 2.9 & $\begin{array}{l}\text { Western } \\
\text { Meadowlark }\end{array}$ & 8.7 \\
\hline $\begin{array}{l}\text { Loggerhead } \\
\text { Shrike }\end{array}$ & 6.0 & Horned Lark & 2.7 & $\begin{array}{l}\text { Loggerhead } \\
\text { Shrike }\end{array}$ & 2.6 & $\begin{array}{l}\text { Loggerhead } \\
\text { Shrike }\end{array}$ & 5.1 \\
\hline \multirow[t]{2}{*}{ Horned Lark } & 5.3 & $\begin{array}{l}\text { Loggerhead } \\
\text { Shrike }\end{array}$ & 2.1 & $\begin{array}{l}\text { Dark-Eyed } \\
\text { Junco }\end{array}$ & 2.0 & Cactus Wren & 2.9 \\
\hline & & & & $\begin{array}{l}\text { White- } \\
\text { Crowned } \\
\text { Sparrow }\end{array}$ & 2.0 & & \\
\hline
\end{tabular}


Table 9. Flight Height Characteristics by Avian Group Observed during Phase I Utilization Surveys at Tehachapi Pass Wind Resource Area, 2 October 1996 to 27 May 1998

\begin{tabular}{|c|c|c|c|c|c|c|c|c|}
\hline \multirow{2}{*}{$\begin{array}{c}\text { Study Area } \\
\text { Group }\end{array}$} & \multirow{2}{*}{$\begin{array}{c}\text { \# Flocks } \\
\text { Flying } \\
\end{array}$} & \multirow{2}{*}{$\begin{array}{c}\text { \# Birds } \\
\text { Flying } \\
\end{array}$} & \multirow{2}{*}{$\begin{array}{c}\text { Mean Flight } \\
\text { Height }(\mathrm{m})\end{array}$} & \multirow{2}{*}{$\begin{array}{c}\% \\
\text { Flying } \\
\end{array}$} & \multicolumn{4}{|c|}{$\%$ in Height (m) Categories } \\
\hline & & & & & $<\overline{10}$ & $10-35$ & $36-60$ & $>60$ \\
\hline \multicolumn{9}{|l|}{ Overall } \\
\hline Raptors & 130 & 146 & 53.58 & 73.7 & 6.8 & 40.4 & 29.5 & 23.3 \\
\hline Corvids & 952 & 1510 & 28.34 & 77.5 & 23.1 & 42.6 & 21.1 & 13.1 \\
\hline Passerines & 703 & 1891 & 7.38 & 59.7 & 69.2 & 25.6 & 1.5 & 3.7 \\
\hline Other & 158 & 484 & 26.17 & 45.3 & 25.2 & 27.9 & 7.0 & 39.9 \\
\hline Total & 1943 & 4031 & 22.27 & 63.2 & 44.4 & 32.8 & 10.5 & 12.3 \\
\hline \multicolumn{9}{|l|}{ West Ridge } \\
\hline Raptors & 91 & 105 & 54.23 & 86.8 & 5.7 & 36.2 & 32.4 & 25.7 \\
\hline Corvids & 664 & 1100 & 28.92 & 81.1 & 22.7 & 39.6 & 24.1 & 13.5 \\
\hline Passerines & 270 & 1119 & 8.07 & 69.3 & 67.6 & 24.0 & 2.5 & 5.8 \\
\hline Other & 95 & 385 & 31.74 & 44.4 & 21.0 & 21.6 & 8.1 & 49.4 \\
\hline Total & 1120 & 2709 & 26.19 & 68.4 & 40.4 & 30.5 & 13.2 & 15.9 \\
\hline \multicolumn{9}{|c|}{ Middle Ridge } \\
\hline Raptors & 27 & 29 & 64.37 & 51.8 & 6.9 & 48.3 & 20.7 & 24.1 \\
\hline Corvids & 159 & 225 & 24.94 & 62.7 & 30.7 & 44.9 & 13.8 & 10.7 \\
\hline Passerines & 182 & 320 & 5.66 & 51.9 & 75.0 & 25.0 & 0.0 & 0.0 \\
\hline Other & 27 & 50 & 19.00 & 39.1 & 40.0 & 52.0 & 4.0 & 4.0 \\
\hline Total & 395 & 624 & 18.35 & 53.8 & 53.0 & 35.4 & 6.3 & 5.3 \\
\hline \multicolumn{9}{|l|}{ East Slope } \\
\hline Raptors & 12 & 12 & 24.33 & 57.1 & 16.7 & 58.3 & 25.0 & 0.0 \\
\hline Corvids & 129 & 185 & 29.50 & 79.1 & 16.2 & 57.8 & 12.4 & 13.5 \\
\hline Passerines & 251 & 452 & 7.89 & 48.4 & 68.8 & 29.9 & 0.2 & 1.1 \\
\hline Other & 36 & 49 & 16.86 & 67.1 & 42.9 & 53.1 & 2.0 & 2.0 \\
\hline Total & 428 & 698 & 15.62 & 55.3 & 52.1 & 39.4 & 4.0 & 4.4 \\
\hline
\end{tabular}


Table 10. Characteristics of Perching Locations

\begin{tabular}{lcccc}
\hline & \multicolumn{2}{c}{ All Birds } & \multicolumn{2}{c}{ Raptors } \\
Perch Type & $\mathbf{n}$ & $\mathbf{\%}$ & $\mathbf{n}$ & \% \\
\hline Large Lattice Turbine & 11 & 1.9 & 5 & 12.5 \\
Small Lattice Turbine & 28 & 4.9 & 3 & 7.5 \\
Small Tubular Turbine & 49 & 8.5 & 2 & 5.0 \\
Large Tubular Turbine & 0 & 0.0 & 0 & 0.0 \\
Vertical Axis Turbine (Wire or Turbine) & 16 & 2.8 & 4 & 10.0 \\
Meteorological Tower (Wire or Tower) & 29 & 5.0 & 9 & 22.5 \\
Powerline/Pole/Conductor & 69 & 12.0 & 11 & 27.5 \\
Fence & 20 & 3.5 & 0 & 0.0 \\
Ground & 105 & 18.3 & 0 & 0.0 \\
Vegetation & 230 & 40.0 & 4 & 10.0 \\
Other & 18 & 3.1 & 2 & 5.0 \\
\hline Subtotal & $\mathbf{5 7 5}$ & $\mathbf{1 0 0 . 0}$ & $\mathbf{4 0}$ & $\mathbf{1 0 0 . 0}$ \\
\hline
\end{tabular}


Table 11. Number of avian Fatalities Observed during This Study at Tehachapi Pass Wind Resource Area, 2 October 1996 to 27 May 1998

\begin{tabular}{|c|c|c|c|c|c|c|}
\hline \multirow[t]{2}{*}{ Study Area / Group } & \multicolumn{3}{|c|}{$\begin{array}{l}\text { Total Fatalities } \\
\quad \% \text { Composition }\end{array}$} & \multicolumn{3}{|c|}{$\begin{array}{c}\text { Carcass Search Fatalities } \\
\text { \% Composition }\end{array}$} \\
\hline & \# & overall & within area & $\#$ & overall & within area \\
\hline \multicolumn{7}{|l|}{ Overall } \\
\hline Raptors & 44 & 34.6 & $\mathrm{n} / \mathrm{a}$ & 26 & 34.7 & $\mathrm{n} / \mathrm{a}$ \\
\hline Corvids & 10 & 7.9 & $\mathrm{n} / \mathrm{a}$ & 4 & 5.3 & $\mathrm{n} / \mathrm{a}$ \\
\hline Passerines & 27 & 21.3 & $\mathrm{n} / \mathrm{a}$ & 15 & 20.0 & $\mathrm{n} / \mathrm{a}$ \\
\hline Other & 46 & 36.2 & $\mathrm{n} / \mathrm{a}$ & 30 & 40.0 & $\mathrm{n} / \mathrm{a}$ \\
\hline Subtotal & 127 & 100.0 & n/a & 75 & 100.0 & $\mathrm{n} / \mathrm{a}$ \\
\hline \multicolumn{7}{|l|}{ West Ridge } \\
\hline Raptors & 32 & 25.2 & 35.2 & 21 & 28.0 & 38.2 \\
\hline Corvids & 9 & 7.1 & 9.9 & 3 & 4.0 & 5.5 \\
\hline Passerines & 13 & 10.2 & 14.3 & 9 & 12.0 & 16.4 \\
\hline Other & 37 & 29.1 & 40.7 & 22 & 29.3 & 40.0 \\
\hline Subtotal & 91 & 71.7 & 100.0 & 55 & 73.3 & 100.0 \\
\hline \multicolumn{7}{|l|}{ Middle Ridge } \\
\hline Raptors & 3 & 2.4 & 18.8 & 2 & 2.7 & 20.0 \\
\hline Corvids & 1 & 0.8 & 6.3 & 1 & 1.3 & 10.0 \\
\hline Passerines & 7 & 5.5 & 43.8 & 2 & 2.7 & 20.0 \\
\hline Other & 5 & 3.9 & 31.3 & 5 & 6.7 & 50.0 \\
\hline Subtotal & 16 & 12.6 & 100.0 & 10 & 13.3 & 100.0 \\
\hline \multicolumn{7}{|l|}{ East Slope } \\
\hline Raptors & 9 & 7.1 & 47.4 & 3 & 4.0 & 30.0 \\
\hline Corvids & 0 & 0.0 & 0.0 & 0 & 0.0 & 0.0 \\
\hline Passerines & 6 & 4.7 & 31.6 & 4 & 5.3 & 40.0 \\
\hline Other & 4 & 3.1 & 21.1 & 3 & 4.0 & 30.0 \\
\hline Subtotal & 19 & 15.0 & 100.0 & 10 & 13.3 & 100.0 \\
\hline
\end{tabular}


Table 12. Composition of Avian Fatalities Observed during Phase I Study Period at Tehachapi Pass Wind Resource Area, 2 October 1996 to 27 May 1998

\begin{tabular}{|c|c|c|}
\hline Avian Group / Species & \multirow{2}{*}{$\begin{array}{l}\text { Number of Fatalities } \\
\text { Raptors }\end{array}$} & \multirow[t]{2}{*}{ Percent of Fatalities } \\
\hline & & \\
\hline Red-Tailed Hawk & 14 & 11.0 \\
\hline Great Horned Owl & 13 & 10.2 \\
\hline American Kestrel & 9 & 7.1 \\
\hline Common Barn Owl & 2 & 1.6 \\
\hline Unidentified Raptor & 1 & 0.8 \\
\hline Unidentified Buteo & 1 & 0.8 \\
\hline Prairie Falcon & 1 & 0.8 \\
\hline Long-Eared Owl & 1 & 0.8 \\
\hline Flammulated Owl & 1 & 0.8 \\
\hline Ferruginous Hawk & 1 & 0.8 \\
\hline \multicolumn{3}{|l|}{ Corvids } \\
\hline Common Raven & 8 & 6.3 \\
\hline Scrub Jay & 2 & 1.6 \\
\hline \multicolumn{3}{|l|}{ Passerines } \\
\hline Western Meadowlark & 6 & 4.7 \\
\hline Unidentified Passerine & 4 & 3.1 \\
\hline European Starling & 3 & 2.4 \\
\hline Horned Lark & 3 & 2.4 \\
\hline White-Crowned Sparrow & 2 & 1.6 \\
\hline Dark-Eyed Junco & 2 & 1.6 \\
\hline Hermit Thrush & 1 & 0.8 \\
\hline Yellow-Rumped Warbler & 1 & 0.8 \\
\hline Unidentified Sparrow & 1 & 0.8 \\
\hline Rock Wren & 1 & 0.8 \\
\hline Loggerhead Shrike $^{a}$ & 1 & 0.8 \\
\hline Brewer's Blackbird & 1 & 0.8 \\
\hline Chipping Sparrow & 1 & 0.8 \\
\hline \multicolumn{3}{|l|}{ Other } \\
\hline Unidentified Bird & 20 & 15.7 \\
\hline Rock Dove & 11 & 8.7 \\
\hline Mourning Dove & 6 & 4.7 \\
\hline Red-Shafted Flicker & 3 & 2.4 \\
\hline Chukar & 2 & 1.6 \\
\hline Greater Roadrunner & 2 & 1.6 \\
\hline California Quail & 2 & 1.6 \\
\hline Total & 127 & 100.0 \\
\hline
\end{tabular}

${ }^{\mathrm{a}}$ located between Middle Ridge and East Slope. 
Table 13. Mean Use Observed during Phase I Utilization Surveys at Tehachapi Pass Wind Resource Area, 2 October 1996 to 27 May 1998 (Calculated Based on Observations Within $200 \mathrm{~m}$ of Site Center: Icl = 95\% Lower Confidence Limit, ucl = 95\% Upper Confidence Limit; Icl Values Less Than Zero were Set to Zero)

\begin{tabular}{|c|c|c|c|c|c|c|c|c|c|c|c|c|c|c|c|}
\hline \multirow[t]{3}{*}{ Study Area } & \multicolumn{15}{|c|}{ Season } \\
\hline & \multicolumn{3}{|c|}{ Overall } & \multicolumn{3}{|c|}{ Spring } & \multicolumn{3}{|c|}{ Summer } & \multicolumn{3}{|c|}{ Fall } & \multicolumn{3}{|c|}{ Winter } \\
\hline & mean & Icl & ucl & mean & $|c|$ & ucl & mean & Icl & ucl & mean & Icl & ucl & mean & Icl & ucl \\
\hline \multicolumn{16}{|l|}{ Overall } \\
\hline Raptors & 0.03 & 0.02 & 0.04 & 0.02 & 0.01 & 0.03 & 0.02 & 0.01 & 0.03 & 0.04 & 0.03 & 0.05 & 0.03 & 0.01 & 0.06 \\
\hline Corvids & 0.32 & 0.27 & 0.36 & 0.49 & 0.38 & 0.60 & 0.27 & 0.22 & 0.31 & 0.26 & 0.22 & 0.31 & 0.33 & 0.26 & 0.40 \\
\hline Passerines & 0.82 & 0.66 & 0.97 & 0.86 & 0.59 & 1.14 & 0.59 & 0.39 & 0.79 & 1.14 & 0.82 & 1.47 & 0.79 & 0.47 & 1.11 \\
\hline Other & 0.09 & 0.04 & 0.13 & 0.25 & 0 & 0.58 & 0.06 & 0.04 & 0.08 & 0.10 & 0.05 & 0.16 & 0.05 & 0.01 & 0.09 \\
\hline Total & 1.25 & 1.08 & 1.42 & 1.61 & 1.17 & 2.05 & 0.93 & 0.73 & 1.14 & 1.55 & 1.21 & 1.89 & 1.20 & 0.87 & 1.54 \\
\hline \multicolumn{16}{|l|}{ West Ridge } \\
\hline Raptors & 0.04 & 0.02 & 0.06 & 0.02 & 0 & 0.04 & 0.04 & 0.02 & 0.05 & 0.04 & 0.02 & 0.07 & 0.05 & 0.01 & 0.10 \\
\hline Corvids & 0.51 & 0.43 & 0.59 & 0.82 & 0.59 & 1.05 & 0.48 & 0.38 & 0.57 & 0.45 & 0.36 & 0.54 & 0.48 & 0.34 & 0.61 \\
\hline Passerines & 0.94 & 0.68 & 1.21 & 0.94 & 0.33 & 1.55 & 0.88 & 0.42 & 1.34 & 1.01 & 0.65 & 1.36 & 1.15 & 0.50 & 1.79 \\
\hline Other & 0.15 & 0.04 & 0.26 & 0.58 & 0 & 1.45 & 0.07 & 0.03 & 0.11 & 0.11 & 0.03 & 0.19 & 0.07 & 0 & 0.14 \\
\hline Total & 1.64 & 1.34 & 1.94 & 2.36 & 1.31 & 3.42 & 1.46 & 0.99 & 1.93 & 1.61 & 1.23 & 1.98 & 1.75 & 1.08 & 2.41 \\
\hline \multicolumn{16}{|l|}{ Middle Ridge } \\
\hline Raptors & 0.04 & 0.02 & 0.06 & 0.01 & 0 & 0.02 & 0.02 & 0.01 & 0.04 & 0.05 & 0.02 & 0.08 & 0.03 & 0 & 0.06 \\
\hline Corvids & 0.25 & 0.18 & 0.31 & 0.24 & 0.10 & 0.38 & 0.17 & 0.11 & 0.22 & 0.22 & 0.15 & 0.29 & 0.23 & 0.14 & 0.33 \\
\hline Passerines & 0.61 & 0.43 & 0.79 & 0.68 & 0.32 & 1.05 & 0.46 & 0.33 & 0.60 & 0.84 & 0.45 & 1.22 & 0.17 & 0.04 & 0.31 \\
\hline Other & 0.05 & 0.02 & 0.08 & 0.03 & 0 & 0.06 & 0.07 & 0.03 & 0.10 & 0.14 & 0.02 & 0.26 & 0.01 & 0 & 0.02 \\
\hline Total & 0.95 & 0.75 & 1.15 & 0.95 & 0.55 & 1.35 & 0.72 & 0.57 & 0.87 & 1.25 & 0.80 & 1.70 & 0.44 & 0.28 & 0.60 \\
\hline \multicolumn{16}{|l|}{ East Slope } \\
\hline Raptors & 0.01 & 0.00 & 0.02 & 0.02 & 0 & 0.04 & 0.00 & 0 & 0.01 & 0.02 & 0.00 & 0.04 & 0 & & \\
\hline Corvids & 0.11 & 0.07 & 0.14 & 0.31 & 0.18 & 0.45 & 0.06 & 0.03 & 0.09 & 0.04 & 0.02 & 0.07 & 0.16 & 0.07 & 0.25 \\
\hline Passerines & 0.92 & 0.50 & 1.33 & 0.95 & 0.69 & 1.22 & 0.27 & 0.18 & 0.37 & 1.65 & 0.73 & 2.57 & 0.86 & 0.45 & 1.26 \\
\hline Other & 0.04 & 0.01 & 0.08 & 0.03 & 0.00 & 0.06 & 0.02 & 0.00 & 0.03 & 0.06 & 0.01 & 0.11 & 0.07 & 0 & 0.17 \\
\hline Total & 1.08 & 0.67 & 1.49 & 1.32 & 1.02 & 1.62 & 0.35 & 0.26 & 0.45 & 1.77 & 0.85 & 2.69 & 1.09 & 0.66 & 1.52 \\
\hline
\end{tabular}


Table 14. Mean Fatality Observed during Phase I Utilization Surveys at Tehachapi Pass Wind Resource Area, 2 October 1996 to 27 May 1998 (Calculated Based on Fatalities Found during Scheduled Carcass Searches: Icl = 95\% Lower Confidence Limit; ucl $=95 \%$ Upper Confidence Limit; Icl Values Less Than Zero were Set to Zero)

\begin{tabular}{|c|c|c|c|}
\hline Study Area/Group & mean & Icl & ucl \\
\hline \multicolumn{4}{|l|}{ Overall } \\
\hline Raptors & 0.027 & 0.016 & 0.038 \\
\hline Corvids & 0.008 & 0 & 0.018 \\
\hline Passerines & 0.017 & 0.008 & 0.026 \\
\hline Other & 0.034 & 0.019 & 0.050 \\
\hline Total & 0.086 & 0.061 & 0.111 \\
\hline \multicolumn{4}{|l|}{ West Ridge } \\
\hline Raptors & 0.056 & 0.031 & 0.080 \\
\hline Corvids & 0.008 & 0 & 0.016 \\
\hline Passerines & 0.025 & 0.001 & 0.041 \\
\hline Other & 0.057 & 0.029 & 0.085 \\
\hline Total & 0.145 & 0.099 & 0.192 \\
\hline \multicolumn{4}{|l|}{ Middle Ridge } \\
\hline Raptors & 0.006 & 0 & 0.015 \\
\hline Corvids & 0.014 & 0 & 0.040 \\
\hline Passerines & 0.009 & 0 & 0.024 \\
\hline Other & 0.024 & 0 & 0.053 \\
\hline Total & 0.053 & 0.012 & 0.095 \\
\hline \multicolumn{4}{|l|}{ East Slope } \\
\hline Raptors & 0.012 & 0 & 0.026 \\
\hline Corvids & 0 & & \\
\hline Passerines & 0.016 & $<0.001$ & 0.032 \\
\hline Other & 0.012 & 0 & 0.026 \\
\hline Total & 0.041 & 0.015 & 0.067 \\
\hline
\end{tabular}


Table 15. Mean Risk Observed During Phase I Utilization Surveys at Tehachapi Pass Wind Resource Area, 2 October 1996 to 27 May 1998 (calculated based on observations of use within $200 \mathrm{~m}$ of site center and fatalities found during scheduled carcass searches: Icl = 95\% Lower Confidence Limit; ucl = 95\% Upper Confidence Limit; Icl Values Less than Zero were Set to Zero)

\begin{tabular}{|c|c|c|c|}
\hline Study Area & mean & Icl & ucl \\
\hline \multicolumn{4}{|l|}{ Overall } \\
\hline Raptors & 0.836 & 0.395 & 1.277 \\
\hline Corvids & 0.025 & 0 & 0.058 \\
\hline Passerines & 0.021 & 0.009 & 0.033 \\
\hline Other & 0.406 & 0.125 & 0.686 \\
\hline Total & 0.070 & 0.047 & 0.092 \\
\hline \multicolumn{4}{|l|}{ West Ridge } \\
\hline Raptors & 1.421 & 0.547 & 2.294 \\
\hline Corvids & 0.015 & 0 & 0.032 \\
\hline Passerines & 0.026 & 0.008 & 0.044 \\
\hline Other & 0.403 & 0.046 & 0.761 \\
\hline Total & 0.090 & 0.058 & 0.123 \\
\hline \multicolumn{4}{|l|}{ Middle Ridge } \\
\hline Raptors & 0.156 & 0 & 0.390 \\
\hline Corvids & 0.055 & 0 & 0.163 \\
\hline Passerines & 0.015 & 0 & 0.039 \\
\hline Other & 0.487 & 0 & 1.137 \\
\hline Total & 0.056 & 0.012 & 0.101 \\
\hline \multicolumn{4}{|l|}{ East Slope } \\
\hline Raptors & 1.187 & 0 & 2.800 \\
\hline Corvids & 0 & & \\
\hline Passerines & 0.018 & 0 & 0.036 \\
\hline Other & 0.279 & 0 & 0.651 \\
\hline Total & 0.038 & 0.010 & 0.065 \\
\hline
\end{tabular}


Table 16. Results of the Searcher Efficiency Trials at Tehachapi by Size of Carcass and Vegetation Type

\begin{tabular}{|c|c|c|c|c|c|c|c|}
\hline $\begin{array}{c}\text { Size of } \\
\text { Carcass/ } \\
\text { Part }\end{array}$ & $\begin{array}{l}\text { Vegetation } \\
\text { Type }\end{array}$ & $\begin{array}{c}\text { Estimated } \\
\text { Probability } \\
\text { of } \\
\text { Detection }\end{array}$ & $\begin{array}{l}\text { Std. } \\
\text { Error }\end{array}$ & $\begin{array}{c}\mathrm{N}- \\
\text { trials }\end{array}$ & $\begin{array}{c}\mathbf{N} \\
\text { Carcasses/ } \\
\text { Parts }\end{array}$ & $\begin{array}{l}95 \% \\
\text { C.I. } \\
\text { LL }\end{array}$ & $\begin{array}{l}95 \% \\
\text { C.I. } \\
\text { UL }\end{array}$ \\
\hline \multicolumn{8}{|c|}{ STUDY 1 (August 1996) } \\
\hline Small & $\begin{array}{l}\text { Small } \\
\text { shrubs }\end{array}$ & 0.75 & 0.078 & 12 & 36 & 0.59 & 0.91 \\
\hline Small & Grass & 0.72 & 0.079 & 12 & 32 & 0.56 & 0.88 \\
\hline Large & $\begin{array}{l}\text { Small } \\
\text { shrubs }\end{array}$ & 0.82 & 0.058 & 12 & 44 & 0.70 & 0.93 \\
\hline Large & Grass & 0.70 & 0.052 & 12 & 64 & 0.60 & 0.81 \\
\hline \multicolumn{8}{|c|}{ STUDY 2 (April 1997) } \\
\hline Small & $\begin{array}{l}\text { Small } \\
\text { shrubs }\end{array}$ & 0.59 & 0.071 & 12 & 44 & 0.47 & 0.71 \\
\hline Small & Grass & 0.56 & 0.054 & 24 & 87 & 0.46 & 0.67 \\
\hline Large & $\begin{array}{l}\text { Small } \\
\text { shrubs }\end{array}$ & 0.86 & 0.055 & 12 & 36 & 0.77 & 0.95 \\
\hline Large & Grass & 0.92 & 0.033 & 12 & 64 & 0.86 & 0.99 \\
\hline \multicolumn{8}{|l|}{ Overall } \\
\hline Small & $\begin{array}{l}\text { Small } \\
\text { shrubs }\end{array}$ & 0.66 & 0.055 & 24 & 80 & 0.57 & 0.75 \\
\hline Small & Grass & 0.60 & 0.044 & 36 & 119 & 0.53 & 0.68 \\
\hline Large & $\begin{array}{l}\text { Small } \\
\text { shrubs }\end{array}$ & 0.84 & 0.040 & 24 & 80 & 0.77 & 0.90 \\
\hline Large & Grass & 0.81 & 0.040 & 36 & 128 & 0.75 & 0.88 \\
\hline Overall & & 0.73 & 0.022 & 60 & 407 & 0.68 & 0.77 \\
\hline
\end{tabular}


Table 17. Results of the Scavenging Trials at Tehachapi Pass by Size of Carcass and Vegetation Type

\begin{tabular}{|c|c|c|c|c|c|c|}
\hline \multirow{2}{*}{ Comparisons } & \multirow{2}{*}{$\mathbf{N}$} & \multirow{2}{*}{$\begin{array}{c}\text { Proportion } \\
\text { Carcasses } \\
\text { Removed } \\
\text { by Day } 8\end{array}$} & \multicolumn{2}{|c|}{$\begin{array}{l}\text { Removal Time } \\
\text { (days) }\end{array}$} & \multicolumn{2}{|c|}{ 95\% Confidence Intervals } \\
\hline & & & Mean & Se & LL & UL \\
\hline \multicolumn{7}{|l|}{ Proximity to turbines } \\
\hline Near turbines & 170 & 0.95 & 2.890 & 0.20 & 2.49 & 3.29 \\
\hline$>400 \mathrm{~m}$ from turbines & 145 & 0.97 & 2.307 & 0.17 & 1.96 & 2.65 \\
\hline \multicolumn{7}{|l|}{ Geographic Area } \\
\hline Zond (West Ridge) & 115 & 0.95 & 2.172 & 0.19 & 1.79 & 2.55 \\
\hline $\begin{array}{l}\text { Cannon/Flowind (Middle } \\
\text { Ridge) }\end{array}$ & 91 & 0.98 & 2.701 & 0.25 & 2.20 & 3.20 \\
\hline SeaWest (East Ridge) & 109 & 0.96 & 3.030 & 0.25 & 2.52 & 3.54 \\
\hline \multicolumn{7}{|l|}{ Season/Experiment } \\
\hline Aug-96 & 114 & 0.96 & 2.195 & 0.19 & 1.81 & 2.58 \\
\hline Dec-96 & 108 & 0.94 & 3.134 & 0.26 & 2.61 & 3.66 \\
\hline Apr-97 & 93 & 0.98 & 2.548 & 0.23 & 2.09 & 3.01 \\
\hline \multicolumn{7}{|l|}{ Size } \\
\hline Small & 161 & 0.94 & 3.101 & 0.21 & 2.68 & 3.53 \\
\hline Large & 154 & 0.99 & 2.120 & 0.15 & 1.81 & 2.43 \\
\hline \multicolumn{7}{|l|}{ Color } \\
\hline Non-cryptic & 210 & 0.97 & 2.446 & 0.16 & 2.13 & 2.76 \\
\hline Cryptic & 105 & 0.95 & 2.971 & 0.25 & 2.47 & 3.48 \\
\hline Overall & 315 & 0.96 & 2.621 & 0.13 & 2.35 & 2.89 \\
\hline
\end{tabular}




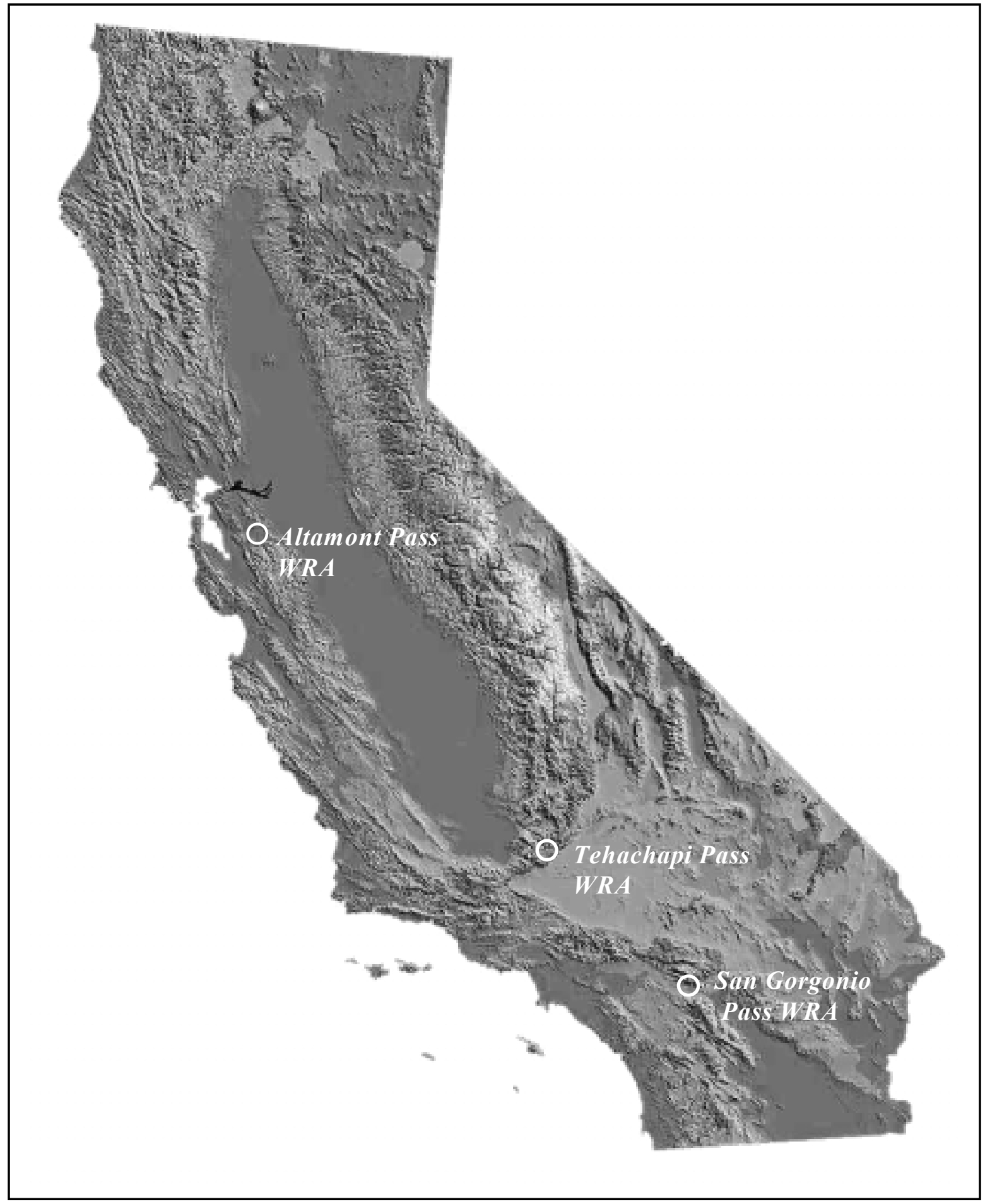

Figure 1. Major developed wind resources areas (WRA) of California 


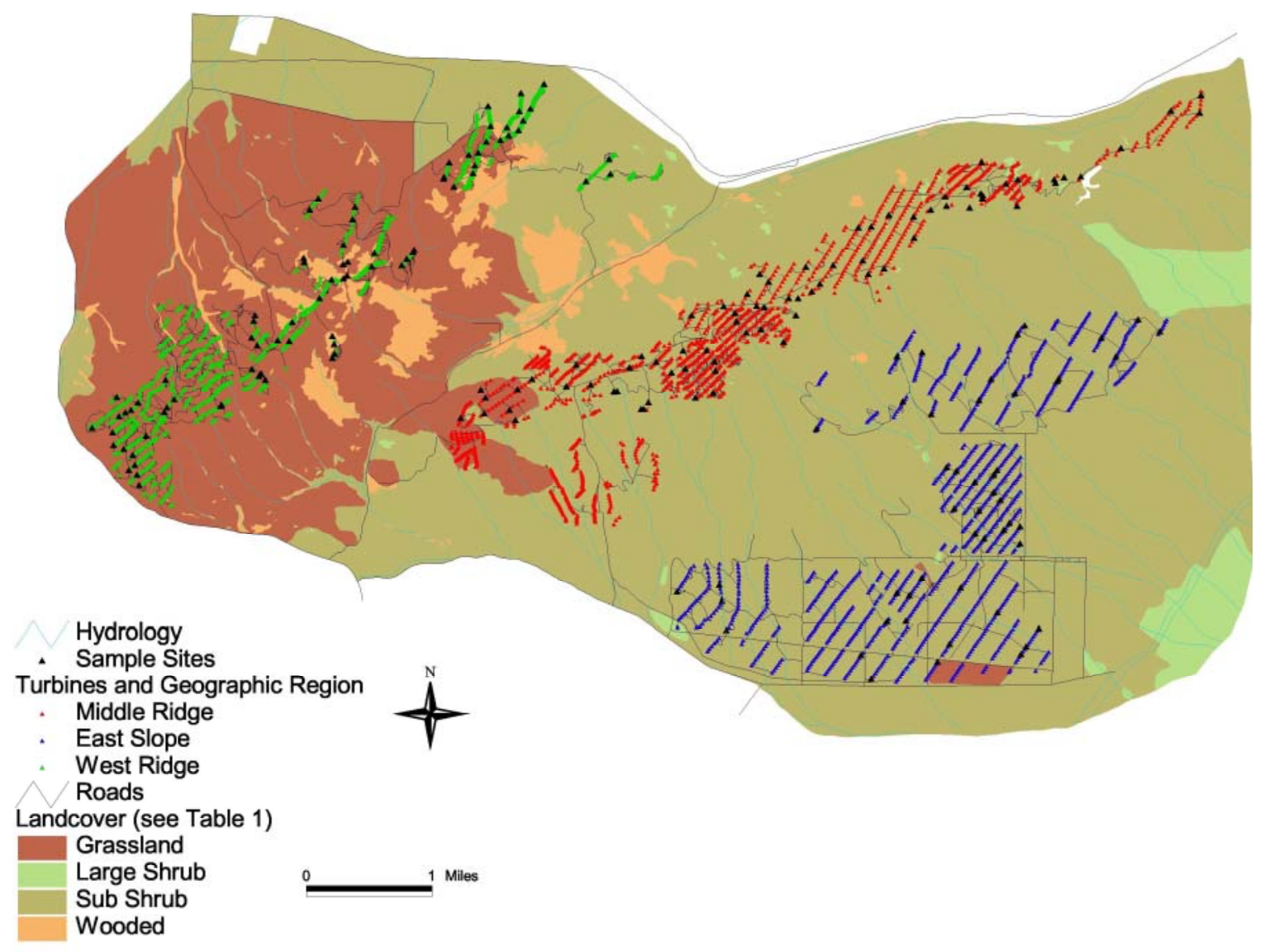

Figure 2. Location of geographic regions and sample site locations at Tehachapi 


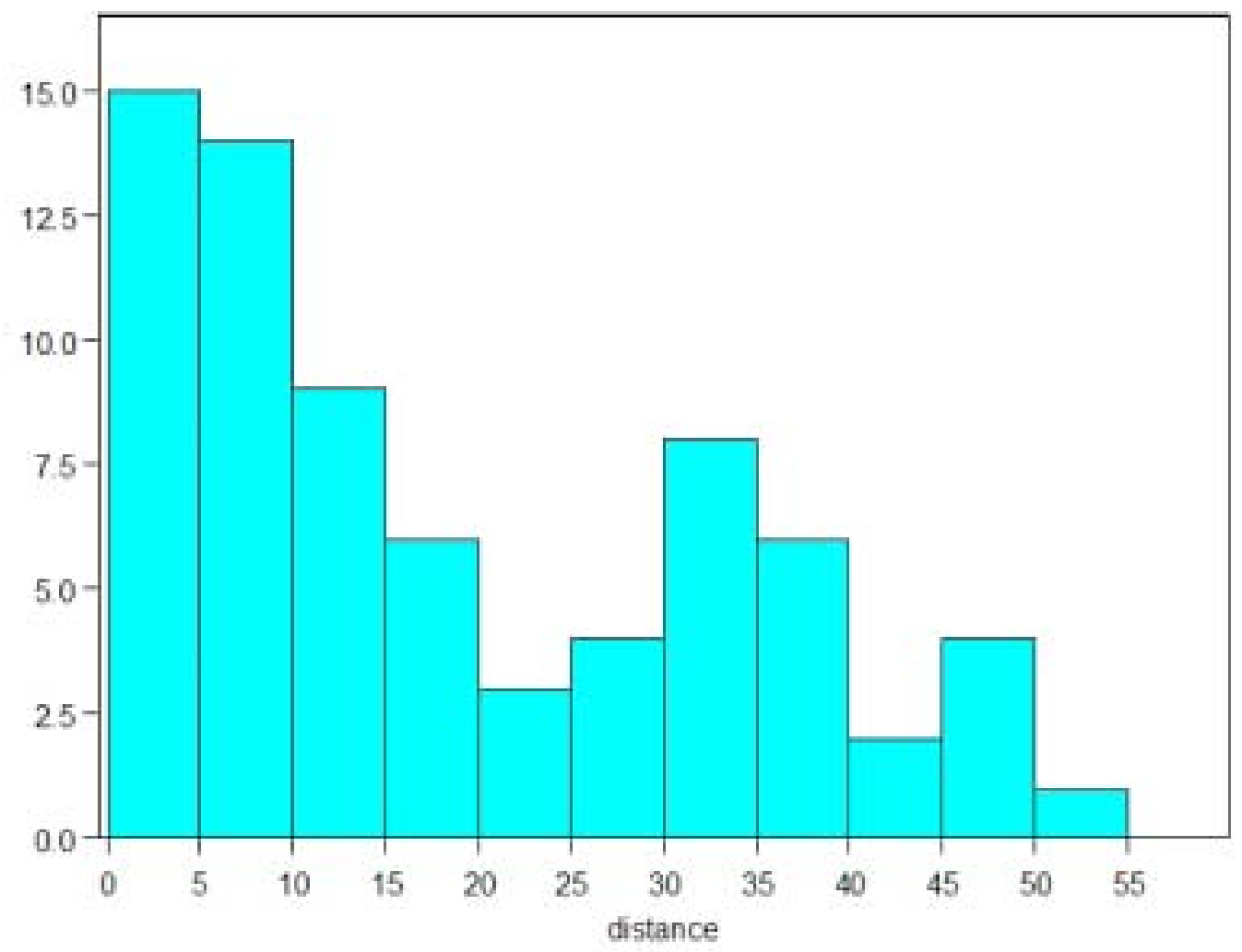

Figure 3. Horizontal distribution of dead birds surrounding the closest turbine observed during Phase I studies at Tehachapi Pass, Wind Resource Area, 2 October 1996 to 27 May 1998, calculated without regard to other structures and whether the turbine is the closest structure 


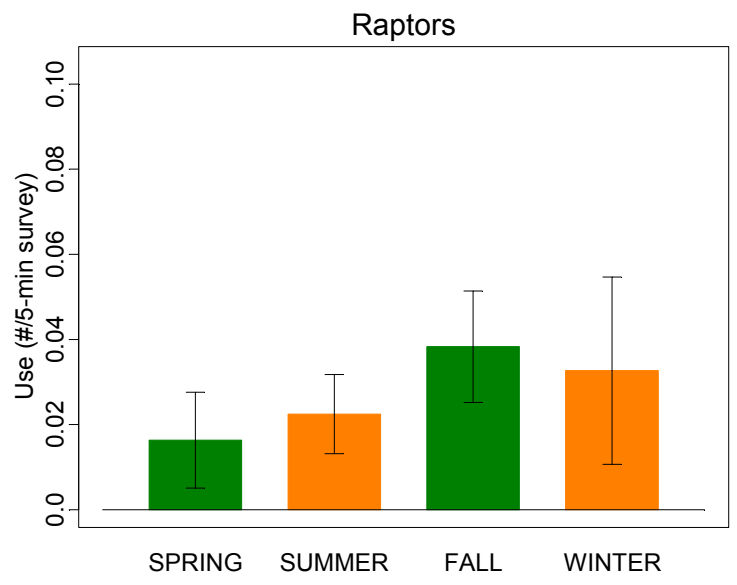

Figure 4. Raptor mean use by season observed during Phase I studies at Tehachapi Pass, Wind Resource Area, 2 October 1996 to 27 May 1998, mean use calculated based on observations within $200 \mathrm{~m}$ of site center

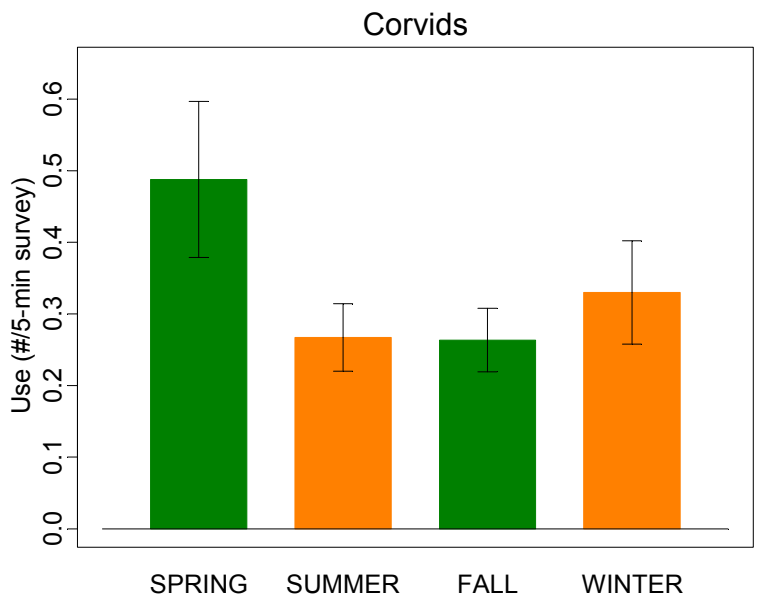

Figure 5. Corvid mean use by season observed during Phase I studies at Tehachapi Pass, Wind Resource Area, 2 October 1996 to 27 May 1998, mean use calculated based on observations within $200 \mathrm{~m}$ of site center 


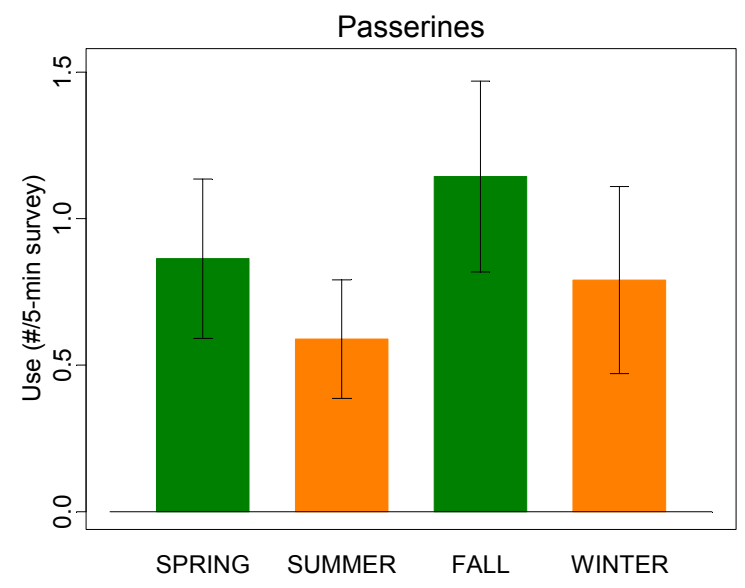

Figure 6. Passerine mean use by season observed during Phase I studies at Tehachapi Pass, Wind Resource Area, 2 October 1996 to 27 May 1998, mean use calculated based on observations within $200 \mathrm{~m}$ of site center

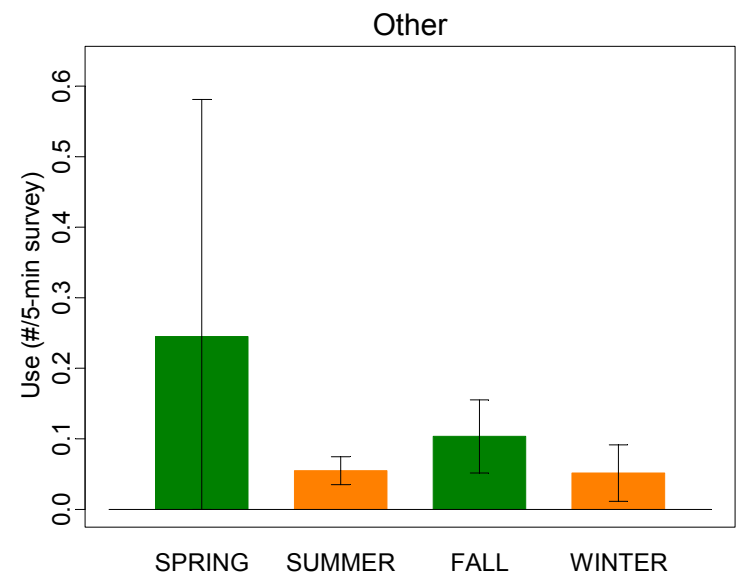

Figure 7. Other bird mean use by season observed during Phase I studies at Tehachapi Pass, Wind Resource Area, 2 October 1996 to 27 May 1998, mean use calculated based on observations within $200 \mathrm{~m}$ of site center 


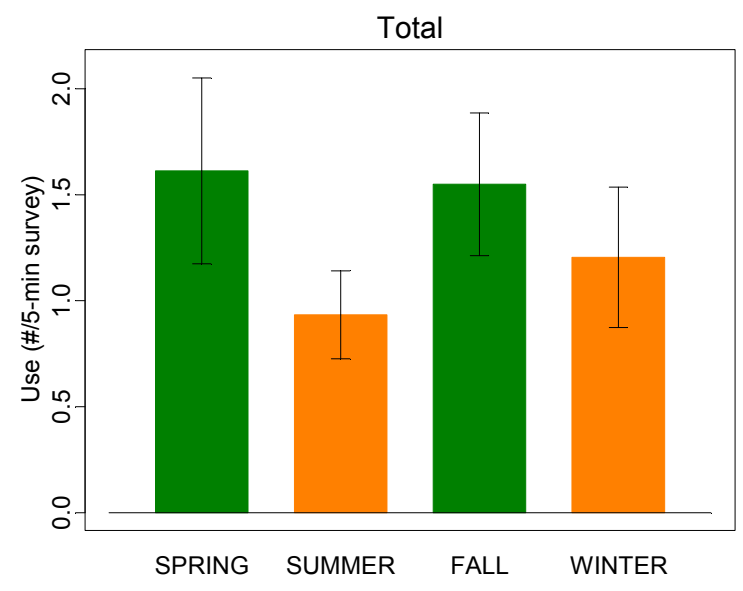

Figure 8. Total bird mean use by season observed during Phase I studies at Tehachapi Pass, Wind Resource Area, 2 October 1996 to 27 May 1998, mean use calculated based on observations within $200 \mathrm{~m}$ of site center 

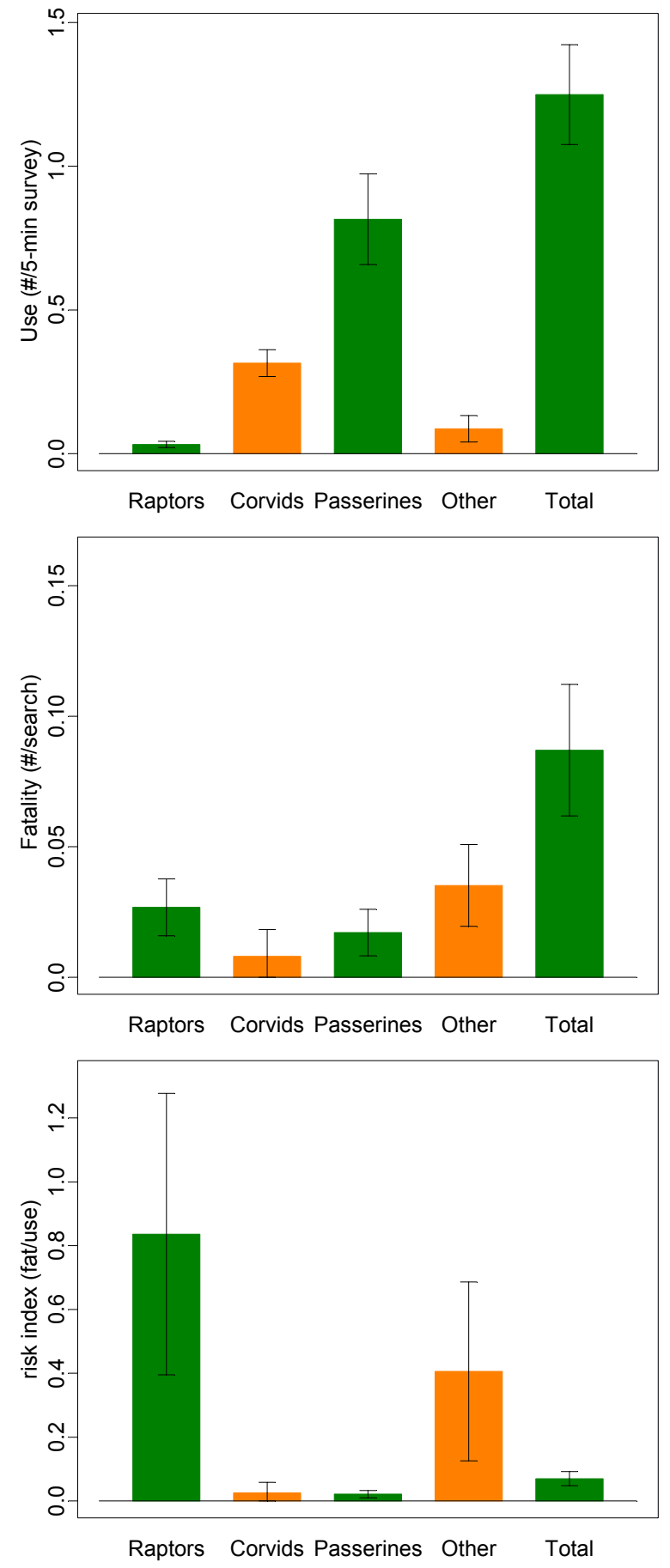

Figure 9. Mean use, fatality rate, and the risk indices by taxonomic group observed during Phase I studies at Tehachapi Pass, Wind Resource Area, 2 October 1996 to 27 May 1998, mean use calculated based on observations within $200 \mathrm{~m}$ of site center 

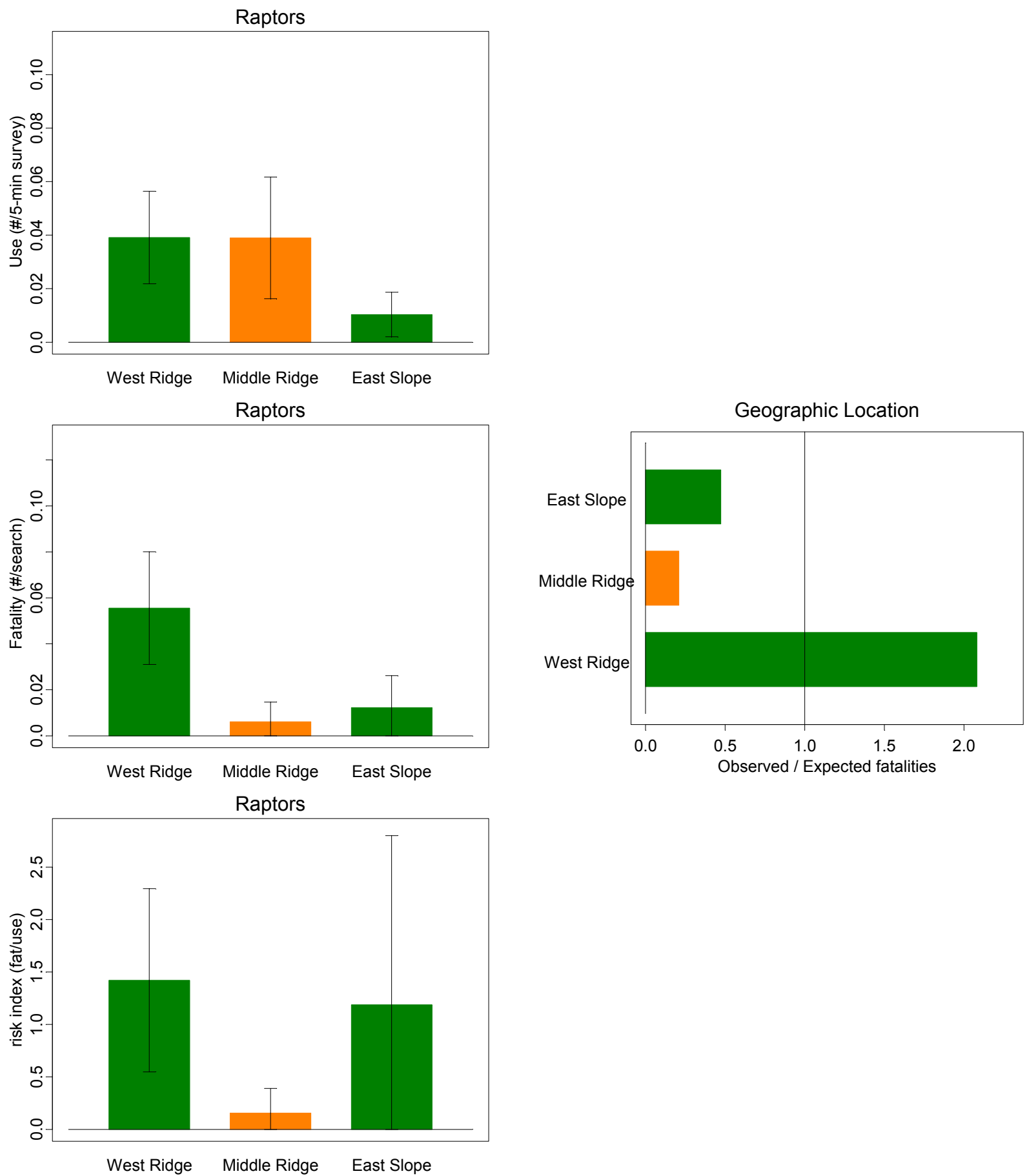

Figure 10. Raptor mean use, fatality rate, observed/expected fatalities, and the risk indices by geographic location observed during Phase I studies at Tehachapi Pass, Wind Resource Area, 2 October 1996 to 27 May 1998, mean use calculated based on observations within $200 \mathrm{~m}$ of site center 

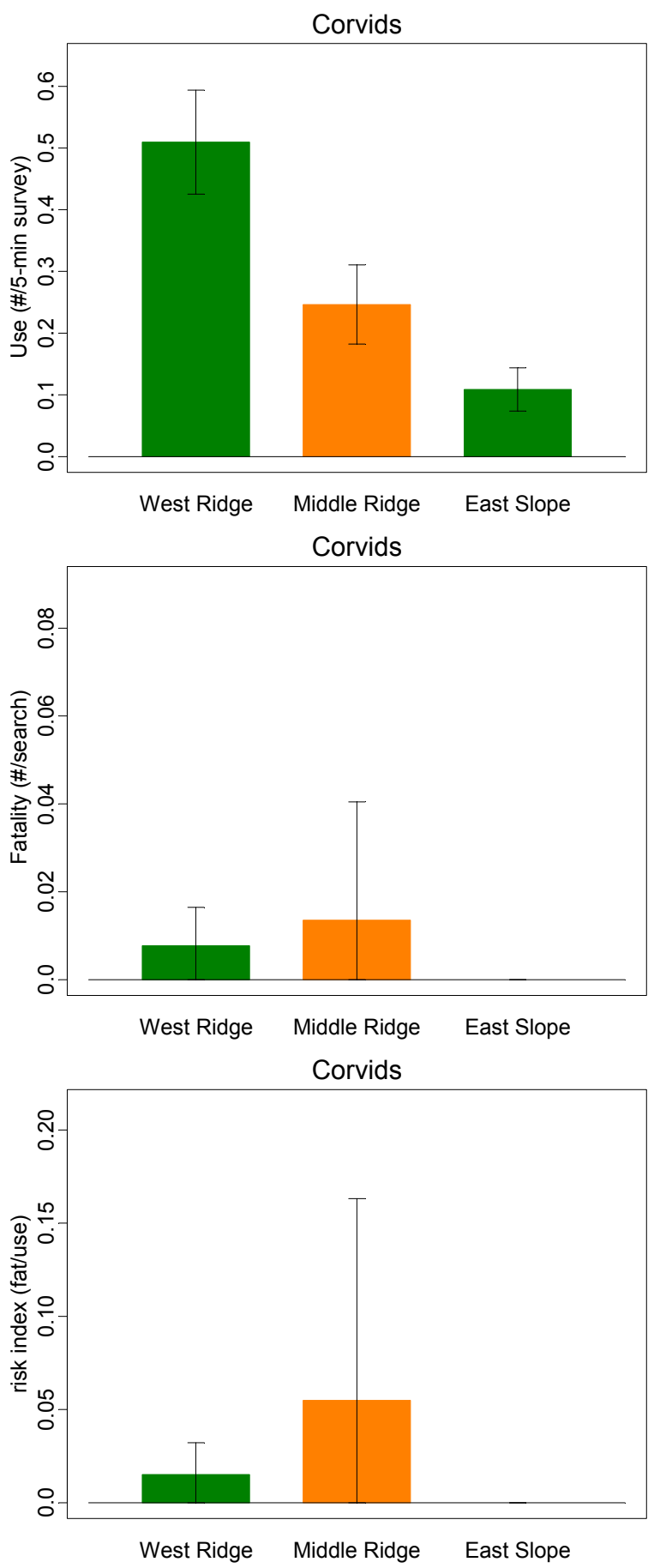

Figure 11. Corvid mean use, fatality rate, and the risk indices by geographic location observed during Phase I studies at Tehachapi Pass, Wind Resource Area, 2 October 1996 to 27 May 1998, mean use calculated based on observations within $200 \mathrm{~m}$ of site center 

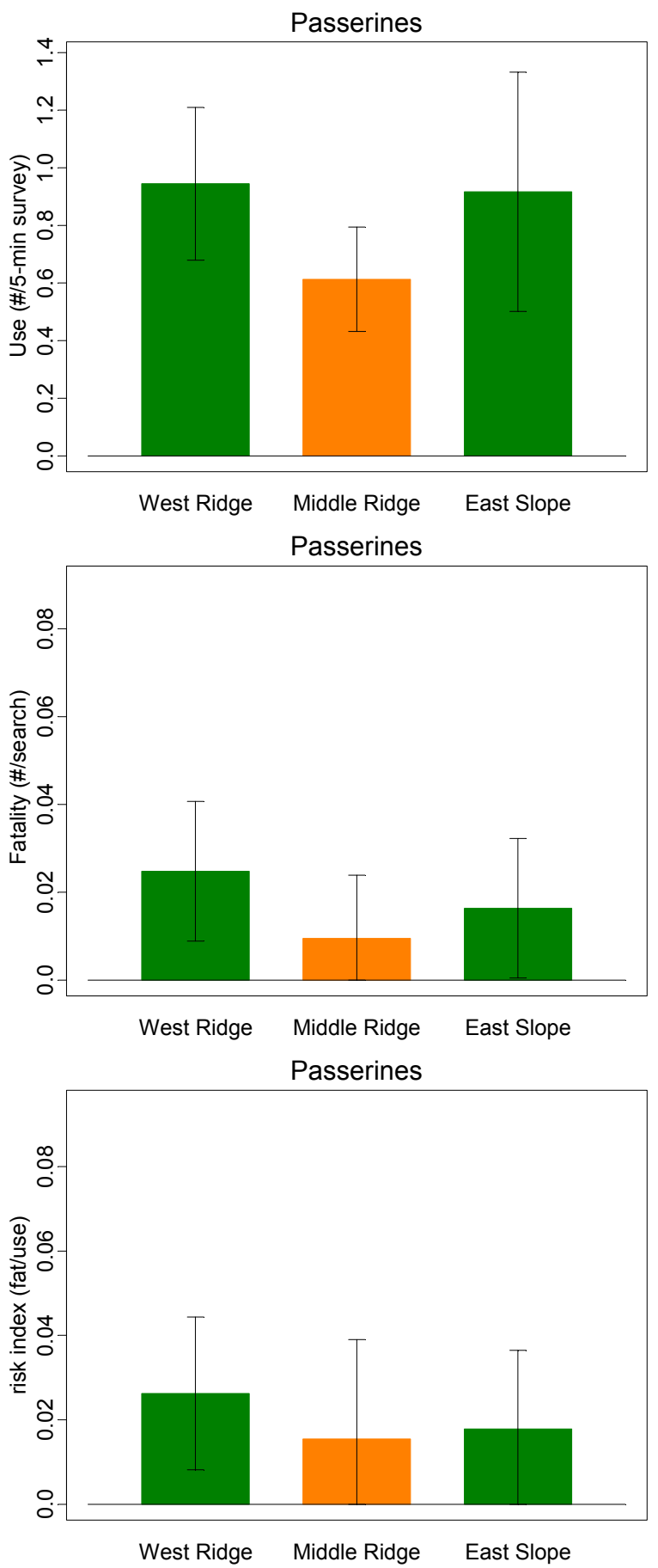

Figure 12. Passerine mean use, fatality rate, and the risk indices by geographic location observed during Phase I studies at Tehachapi Pass, Wind Resource Area, 2 October 1996 to 27 May 1998, mean use calculated based on observations within $200 \mathrm{~m}$ of site center 

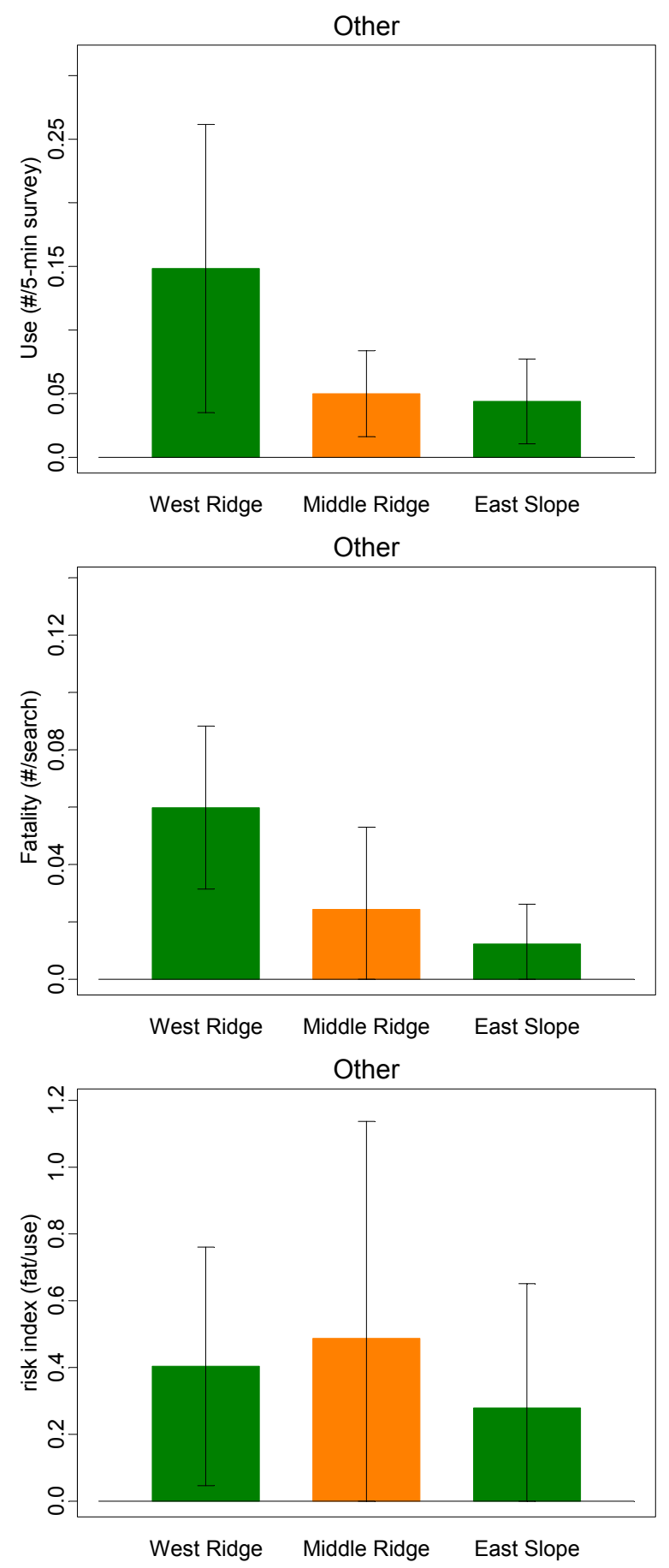

Figure 13. Other bird mean use, fatality rate, and the risk indices by geographic location observed during Phase I studies at Tehachapi Pass, Wind Resource Area, 2 October 1996 to 27 May 1998, mean use calculated based on observations within $200 \mathrm{~m}$ of site center 

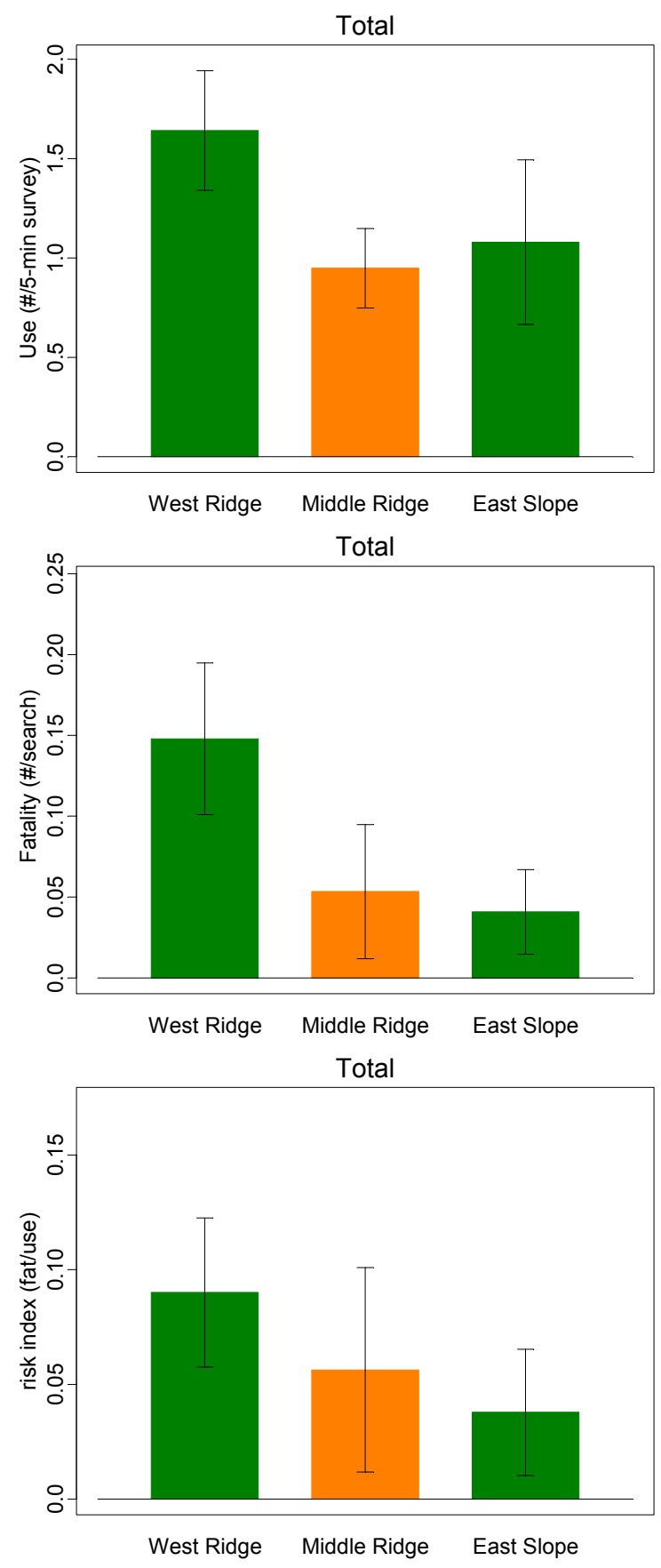

Figure 14. Total bird mean use, fatality rate, and the risk indices by geographic location observed during Phase I studies at Tehachapi Pass, Wind Resource Area, 2 October 1996 to 27 May 1998, mean use calculated based on observations within 200 m of site center 

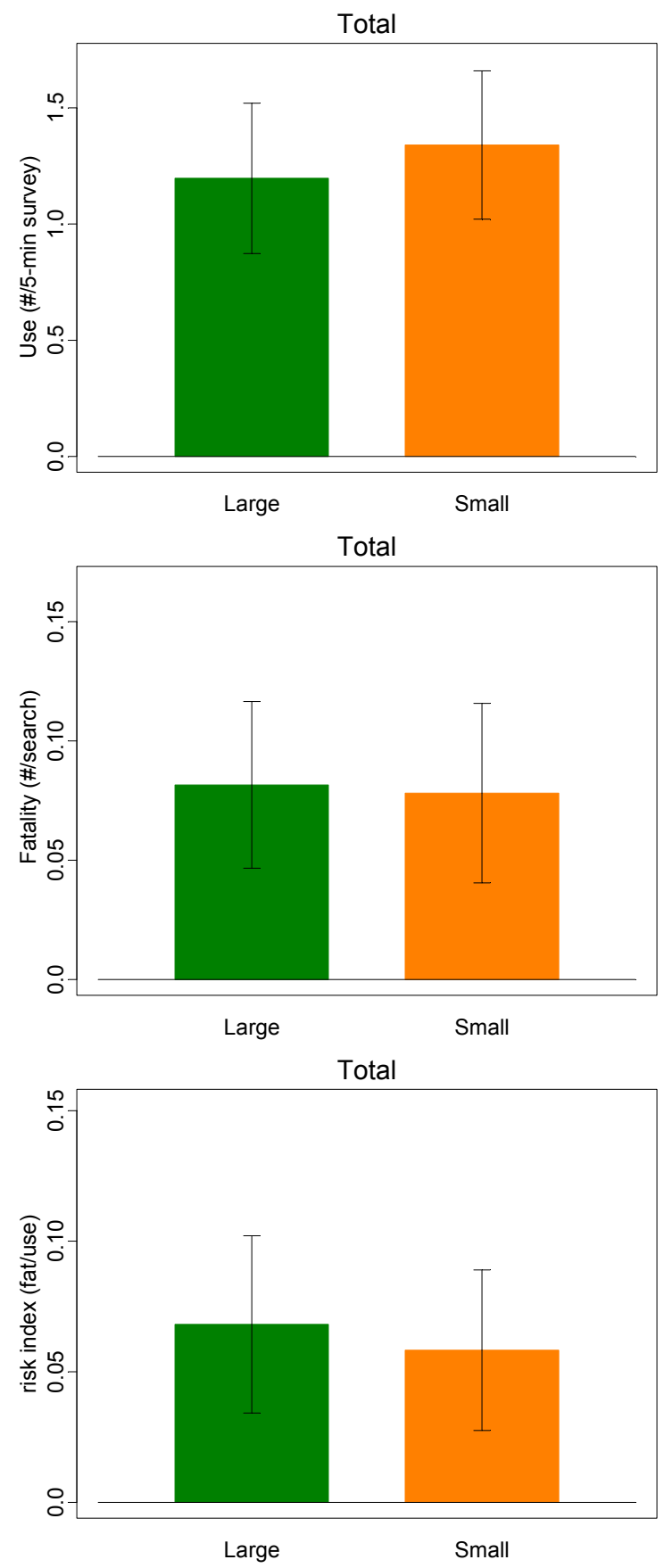

Figure 15. Total bird mean use, fatality rate, and the risk indices by size of turbine (large and small) observed during Phase I studies at Tehachapi Pass, Wind Resource Area, 2 October 1996 to 27 May 1998, mean use calculated based on observations within $200 \mathrm{~m}$ of site center 

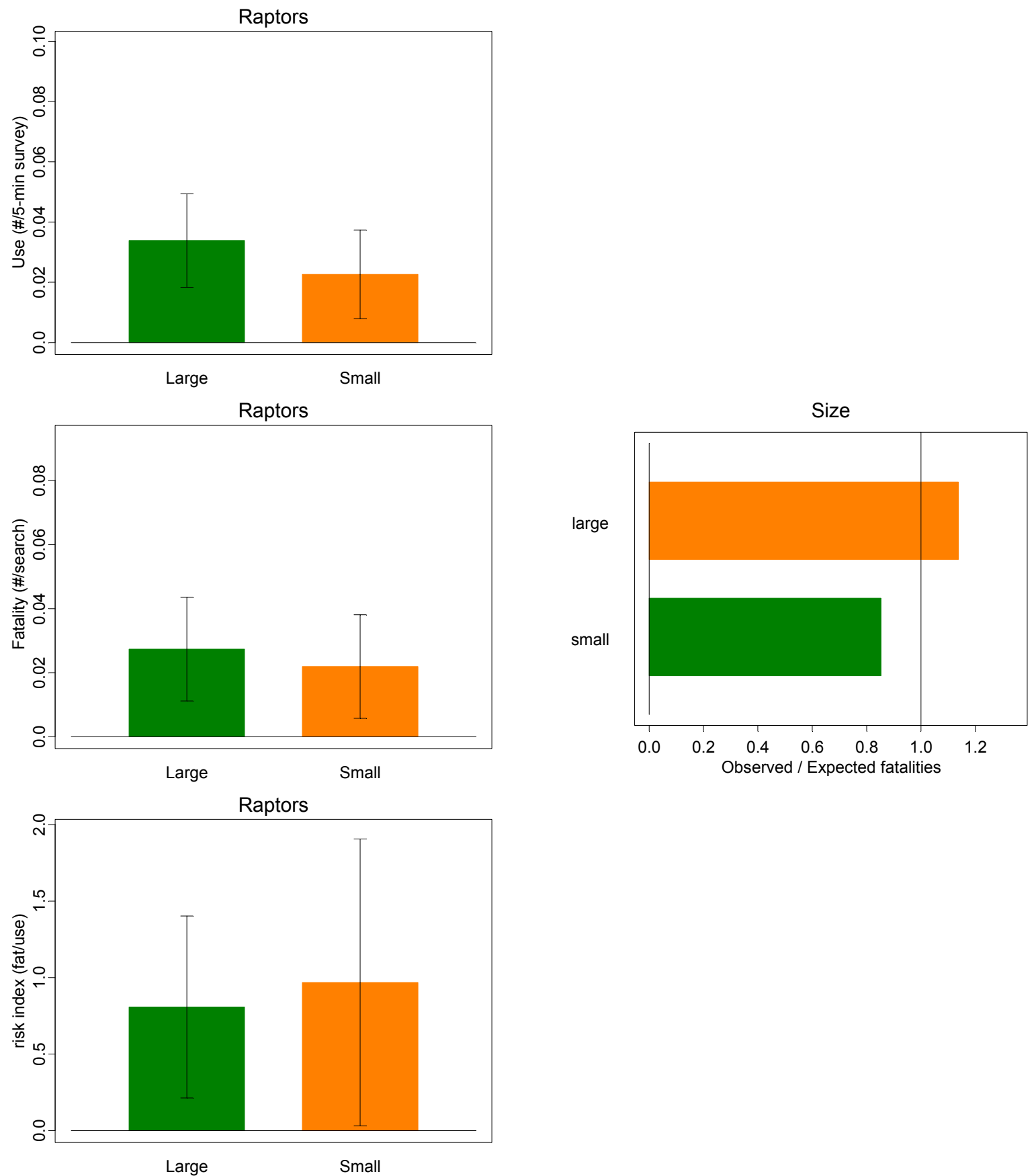

Figure 16. Raptor mean use, fatality rate, observed/expected fatalities, and the risk indices by size of turbine (large and small) observed during Phase I studies at Tehachapi Pass, Wind Resource Area, 2 October 1996 to 27 May 1998, mean use calculated based on observations within $200 \mathrm{~m}$ of site center 

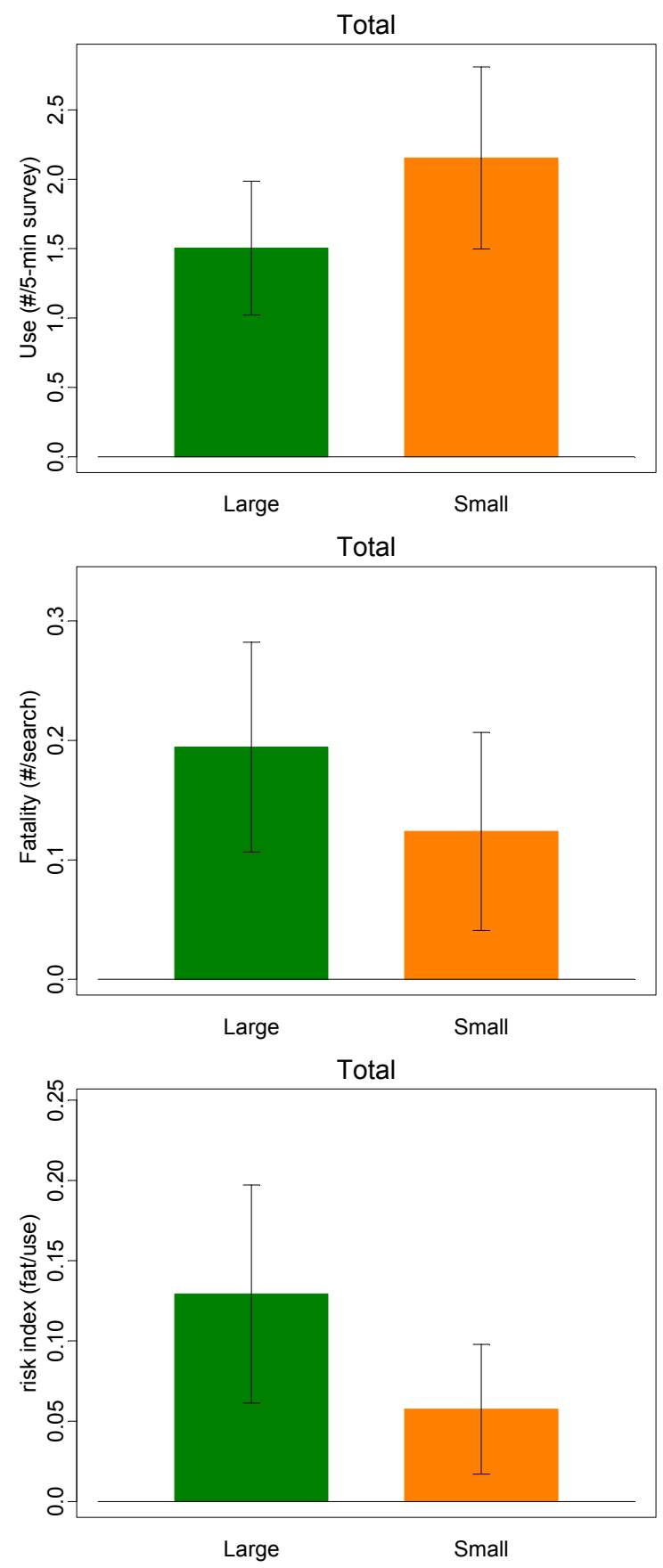

Figure 17. Total bird mean use, fatality rate, and the risk indices by size of turbine (large and small) observed within the West Ridge during Phase I studies at Tehachapi Pass, Wind Resource Area, 2 October 1996 to 27 May 1998, mean use calculated based on observations within $200 \mathrm{~m}$ of site center 

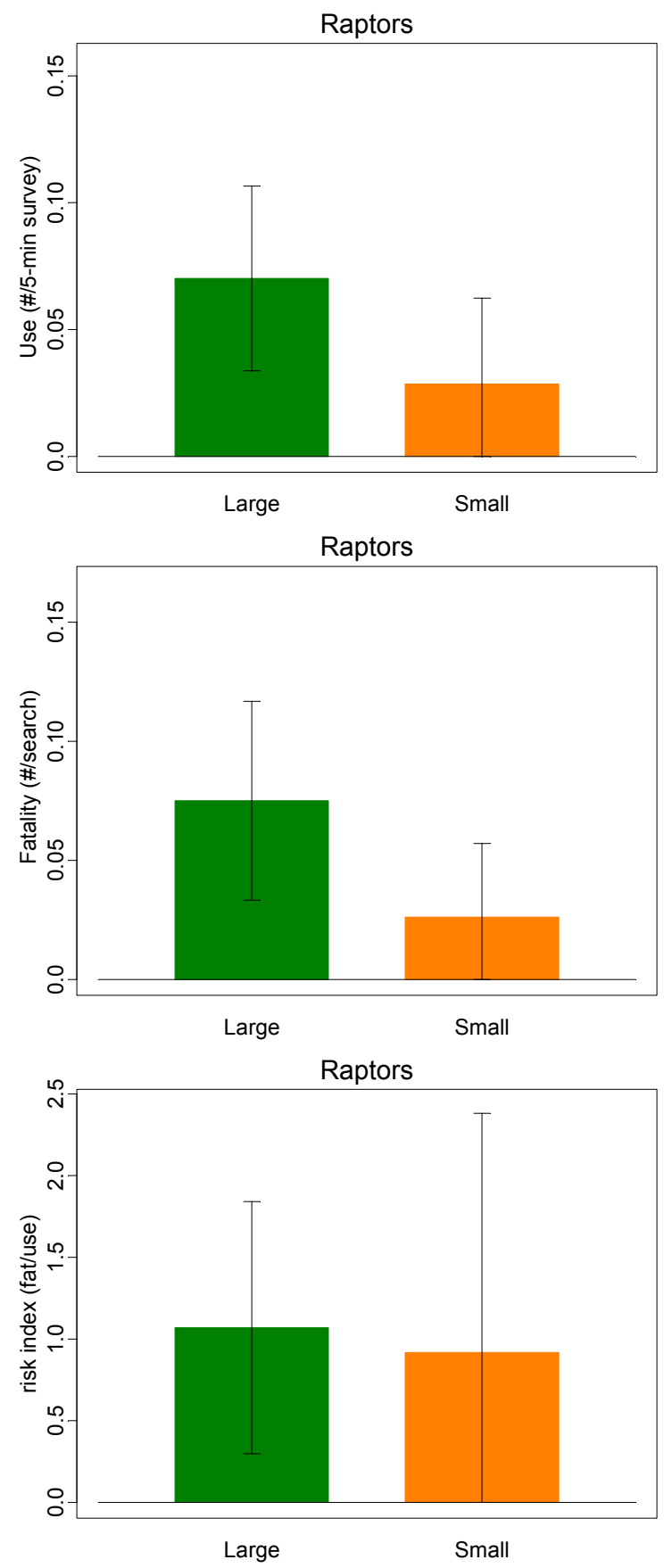

Figure 18. Raptor mean use, fatality rate, observed/expected fatalities, and the risk indices by size of turbine (large and small) observed within the West Ridge during Phase I studies at Tehachapi Pass, Wind Resource Area, 2 October 1996 to 27 May 1998, mean use calculated based on observations within $200 \mathrm{~m}$ of site center 

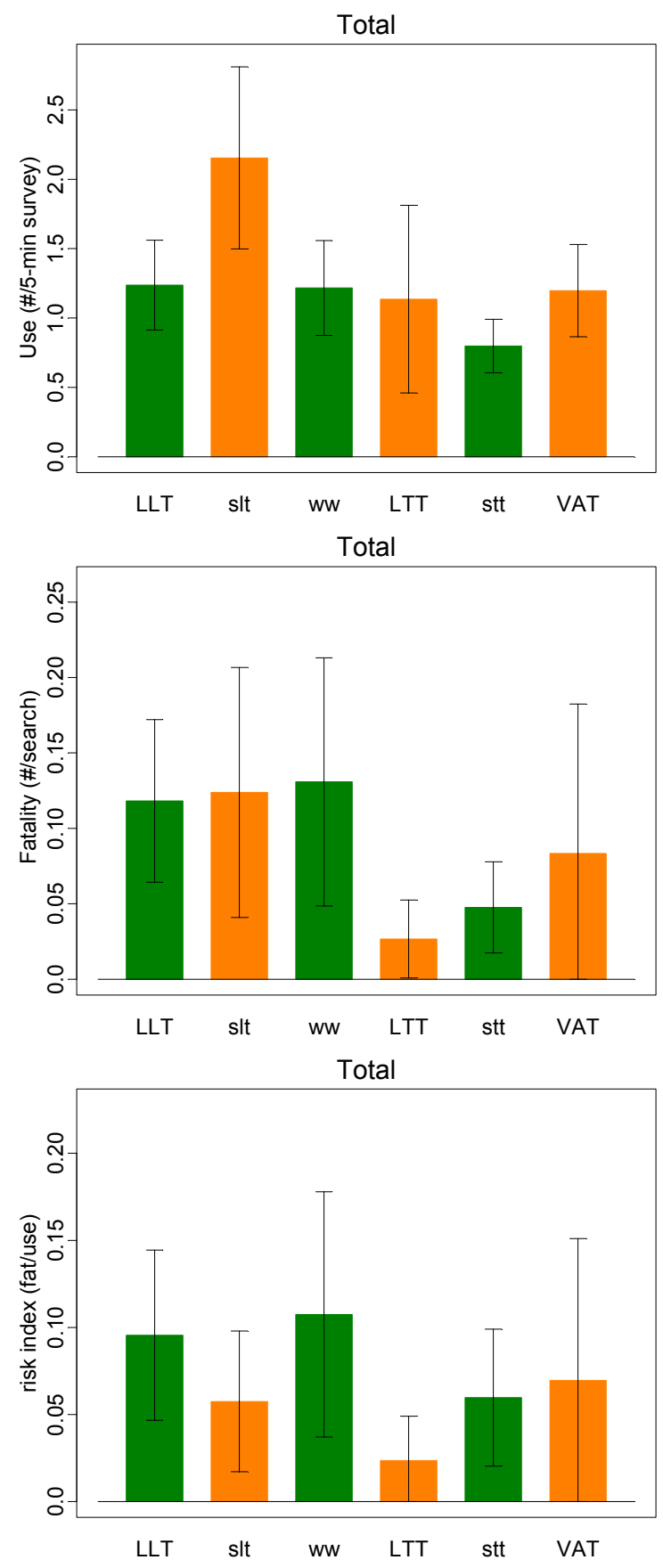

Figure 19. Total bird mean use, fatality rate, and the risk indices by turbine type observed during Phase I studies at Tehachapi Pass, Wind Resource Area, 2 October 1996 to 27 May 1998, mean use calculated based on observations within $200 \mathrm{~m}$ of site center 

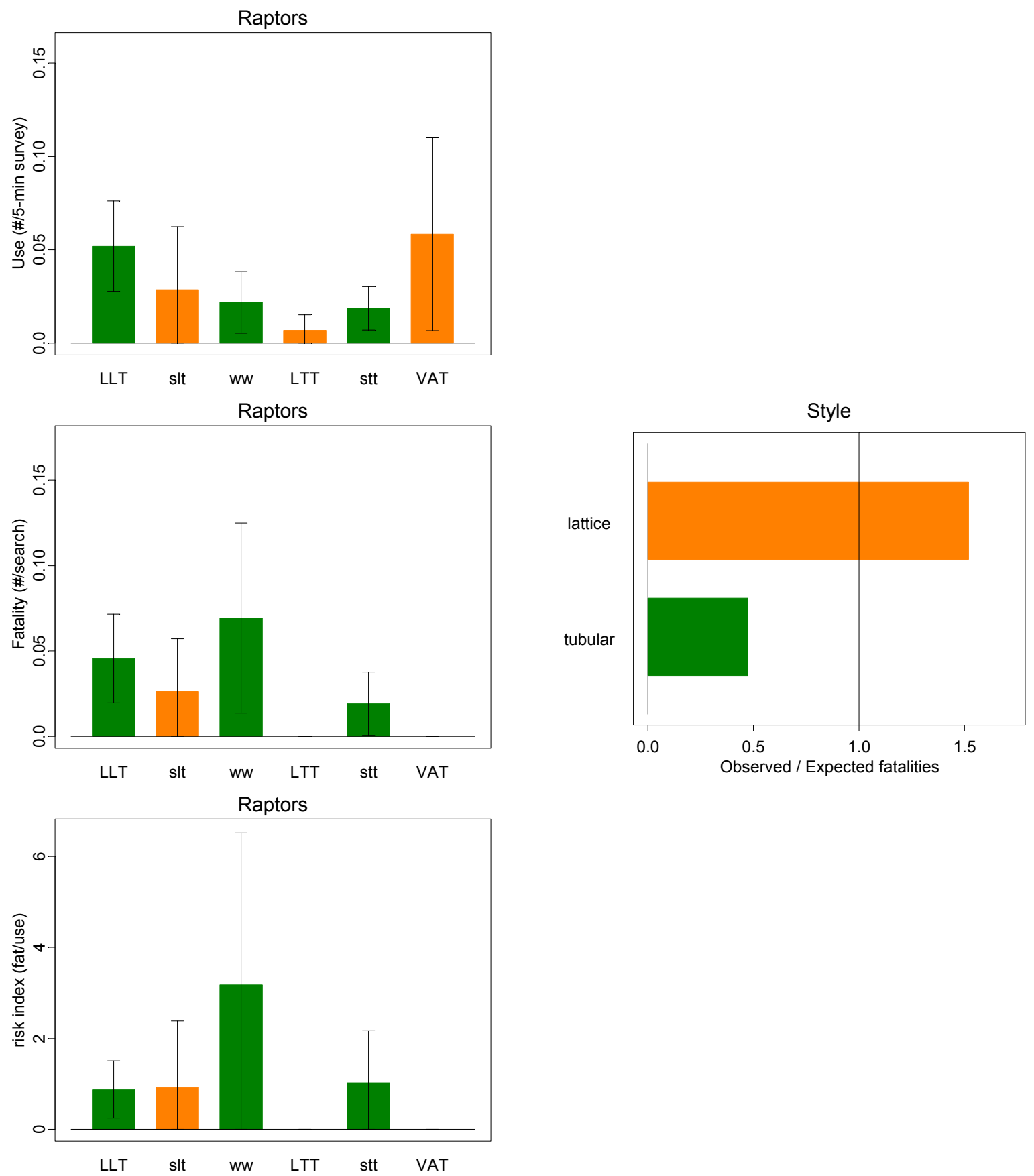

Figure 20. Raptor mean use, fatality rate, observed/expected fatalities, and the risk indices by turbine type observed during Phase I studies at Tehachapi Pass, Wind Resource Area, 2 October 1996 to 27 May 1998, mean use calculated based on observations within $200 \mathrm{~m}$ of site center 

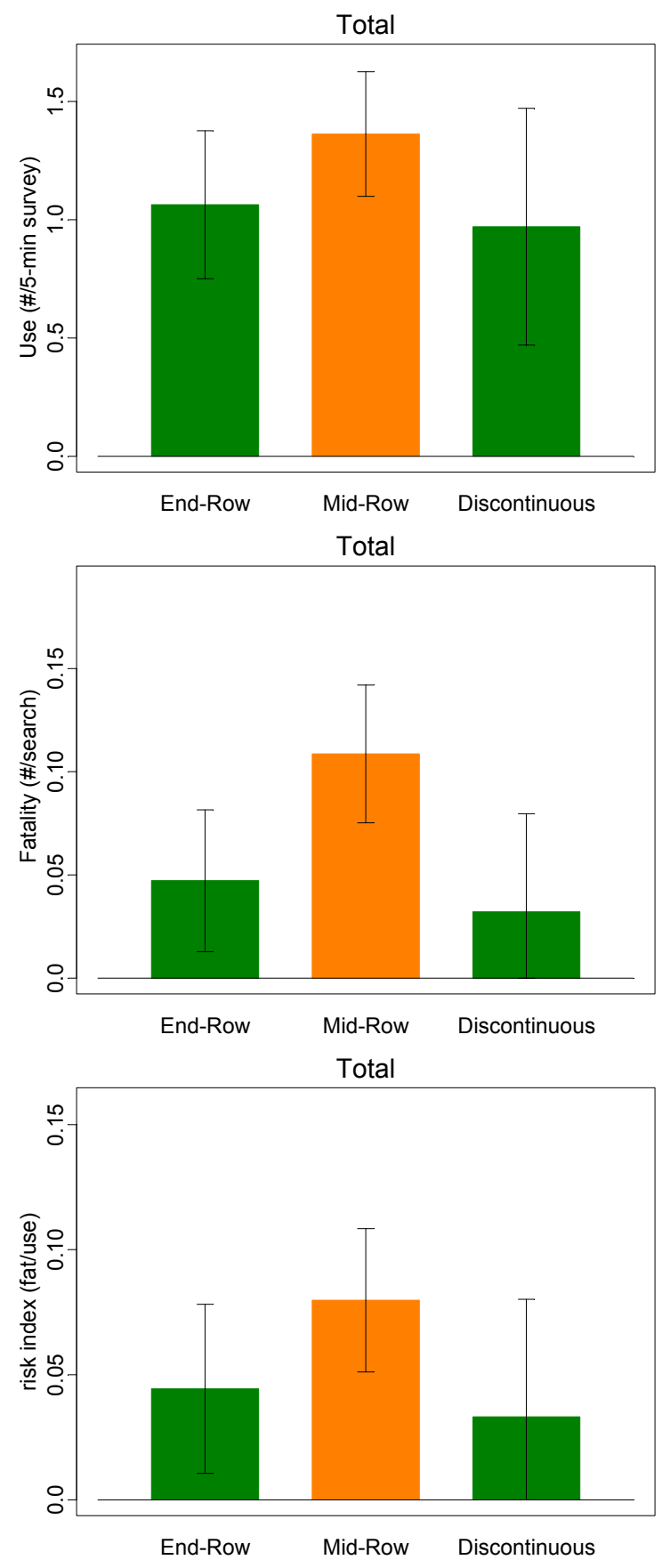

Figure 21. Total bird mean use, fatality rate, and the risk indices by row location observed during Phase I studies at Tehachapi Pass, Wind Resource Area, 2 October 1996 to 27 May 1998, mean use calculated based on observations within $200 \mathrm{~m}$ of site center 

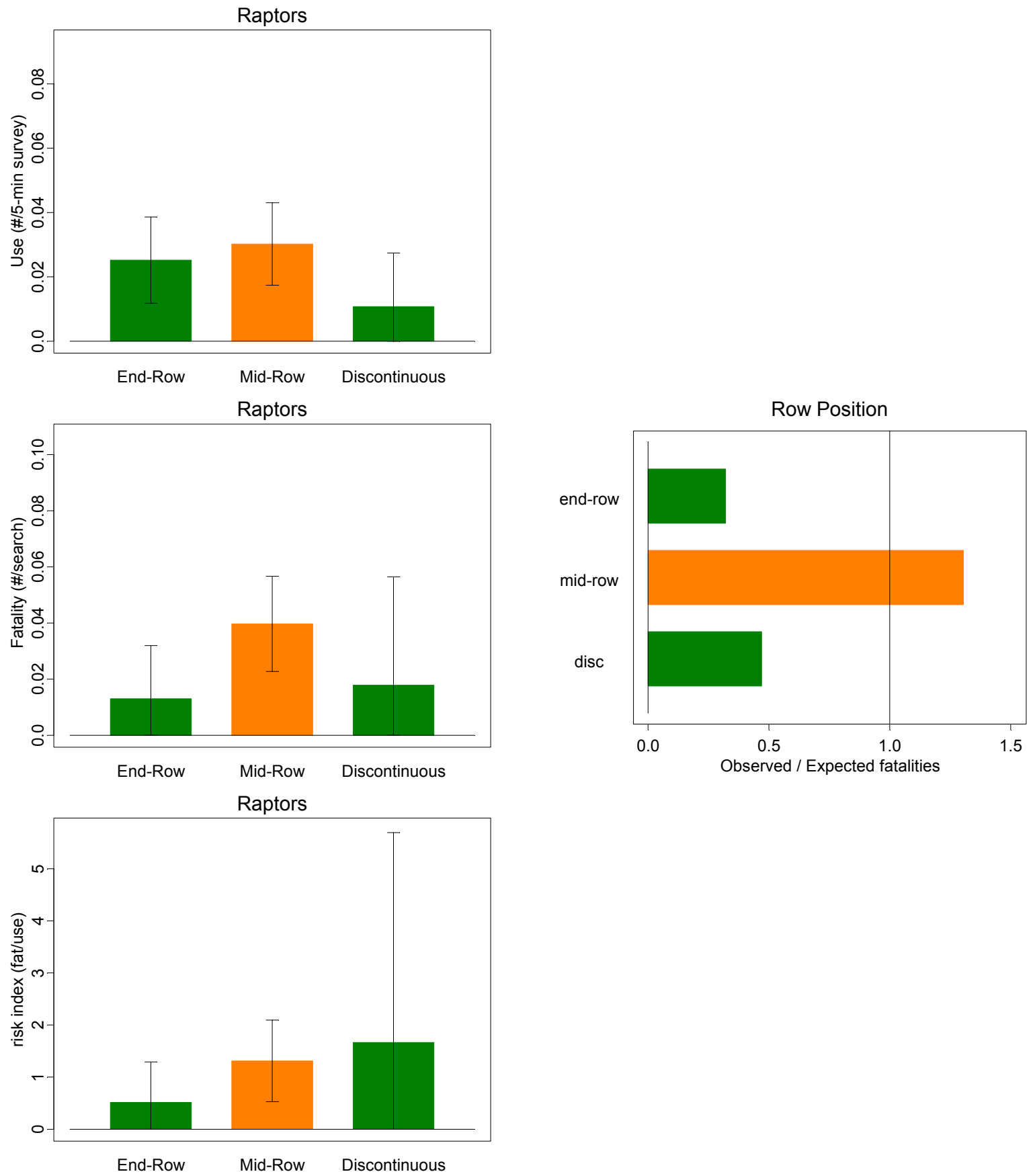

Figure 22. Raptor mean use, fatality rate, observed/expected fatalities, and the risk indices by row location observed during Phase I studies at Tehachapi Pass, Wind Resource Area, 2 October 1996 to 27 May 1998, mean use calculated based on observations within $200 \mathrm{~m}$ of site center 

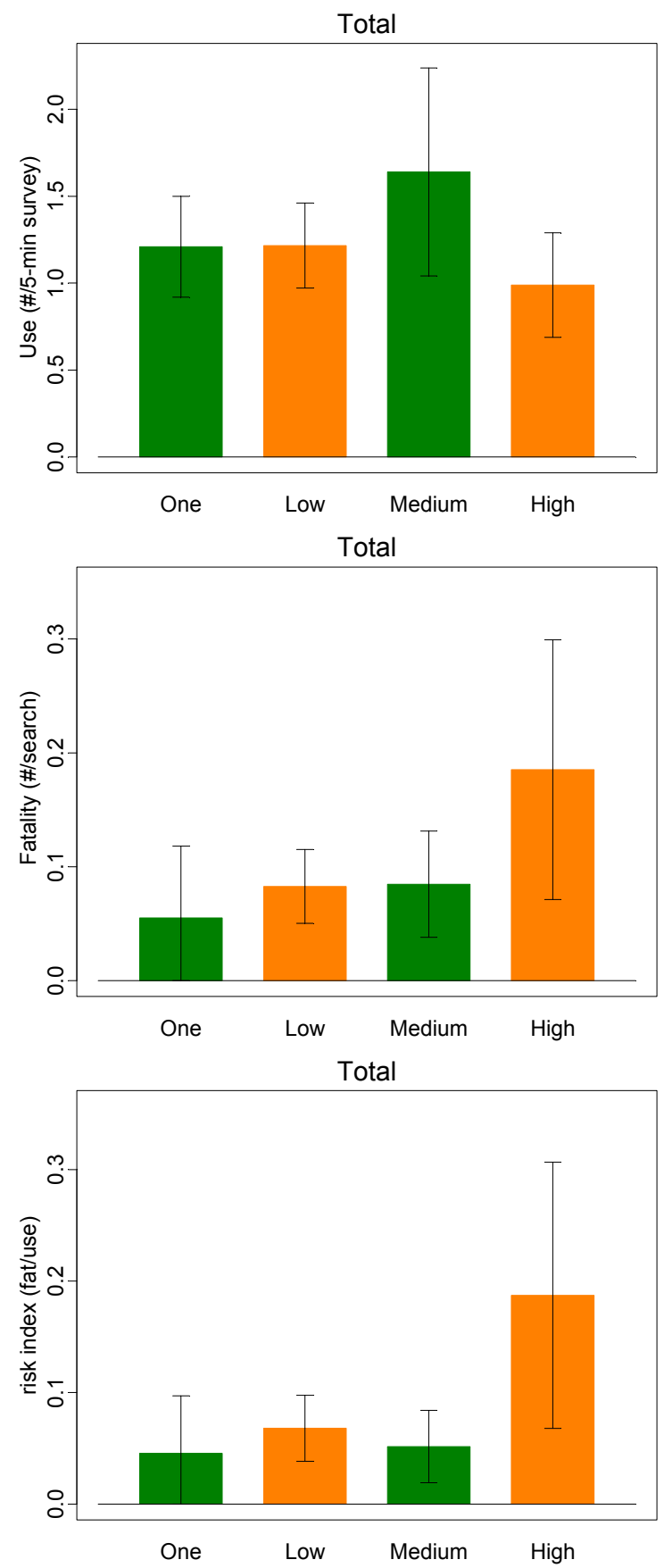

Figure 23. Total bird mean use, fatality rate, and the risk indices by turbine density observed during Phase I studies at Tehachapi Pass, Wind Resource Area, 2 October 1996 to 27 May 1998, mean use calculated based on observations within $200 \mathrm{~m}$ of site center 

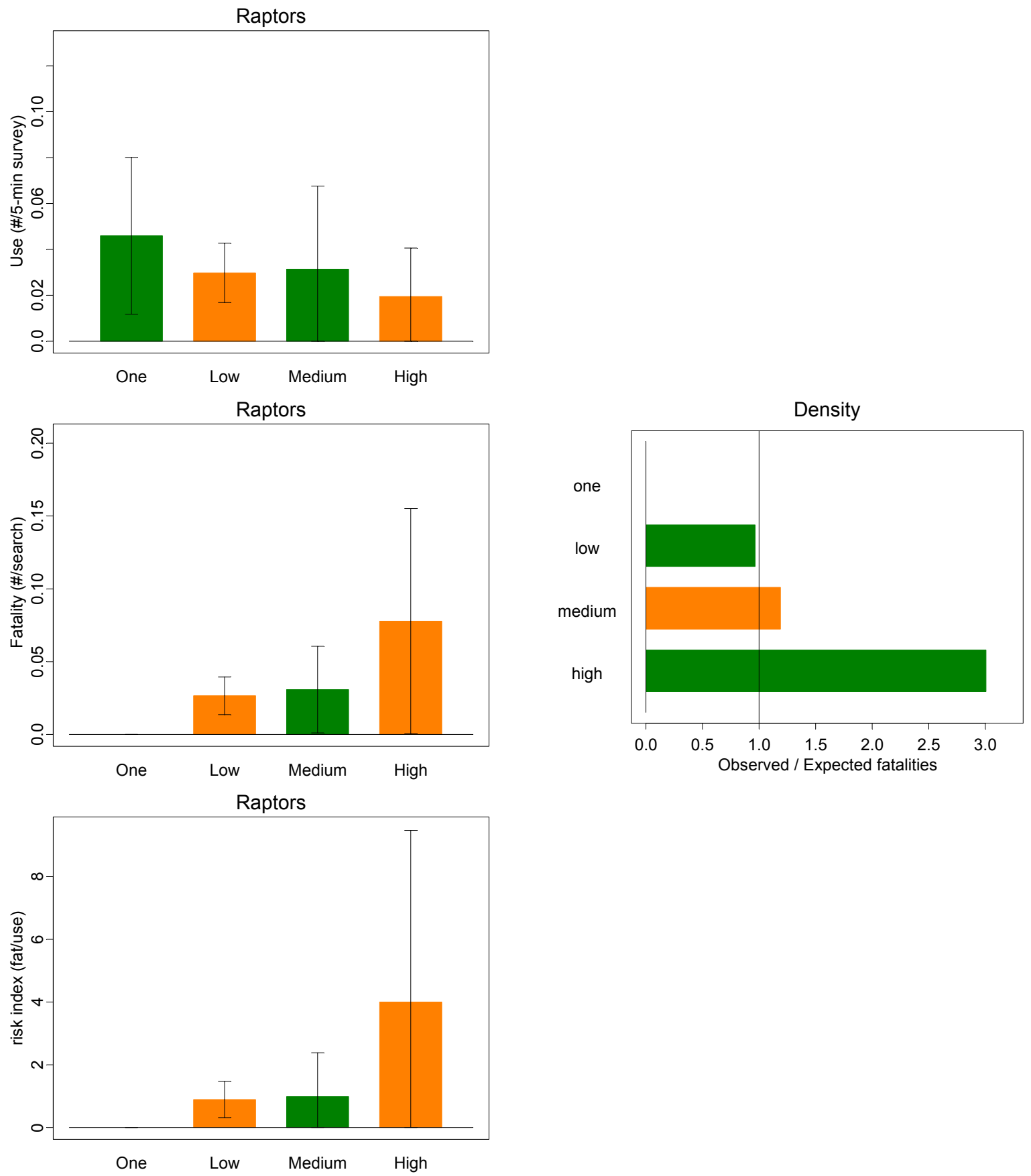

Figure 24. Raptor mean use, fatality rate, observed/expected fatalities, and the risk indices by turbine density observed during Phase I studies at Tehachapi Pass, Wind Resource Area, 2 October 1996 to 27 May 1998, mean use calculated based on observations within 200 m of site center 

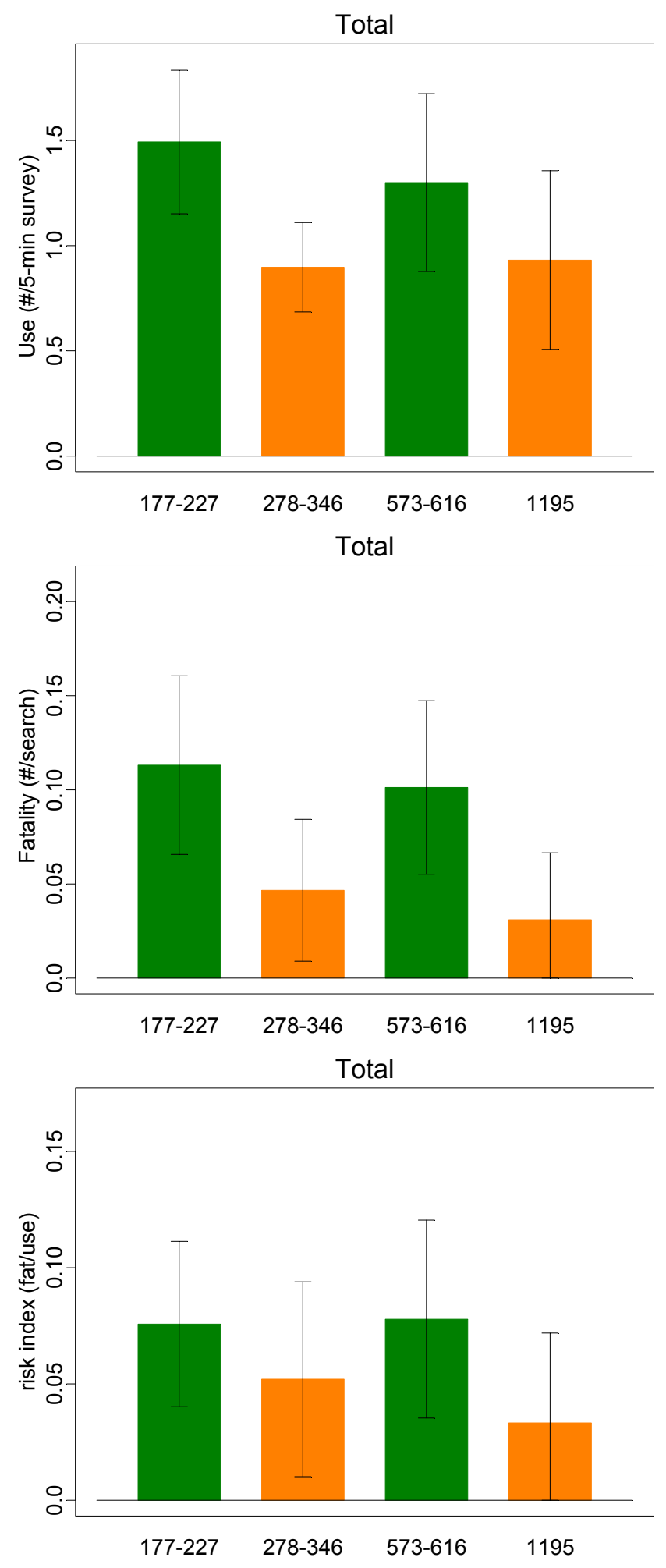

Figure 25. Total birds mean use, fatality rate, and the risk indices by rotor swept area of turbine observed during Phase I studies at Tehachapi Pass, Wind Resource Area, 2 October 1996 to 27 May 1998, mean use calculated based on observations within $200 \mathrm{~m}$ of site center 

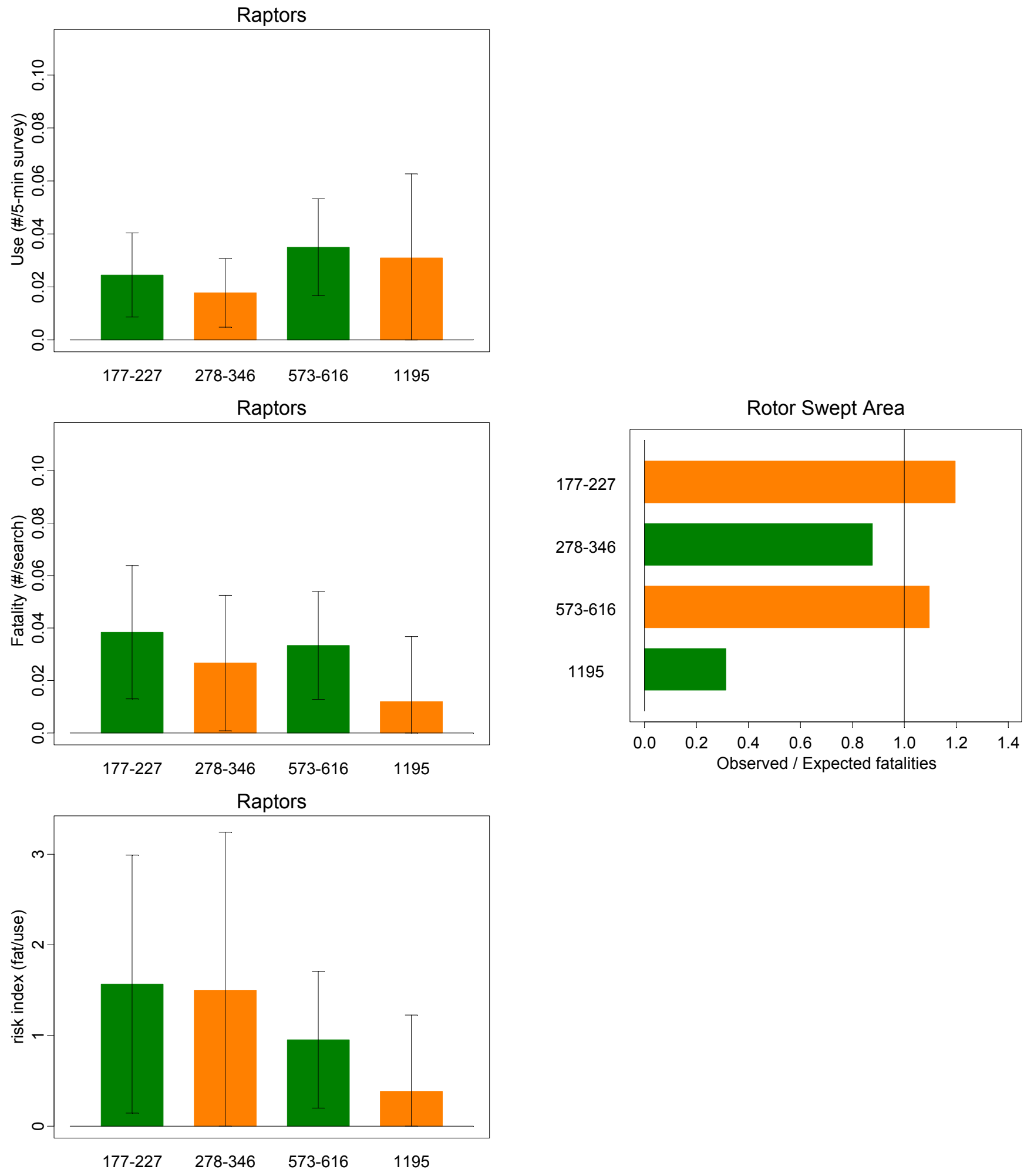

Figure 26. Raptor mean use, fatality rate, observed/expected fatalities, and the risk indices by rotor swept area of turbine observed during Phase I studies at Tehachapi Pass, Wind Resource Area, 2 October 1996 to 27 May 1998, mean use calculated based on observations within $200 \mathrm{~m}$ of site center 

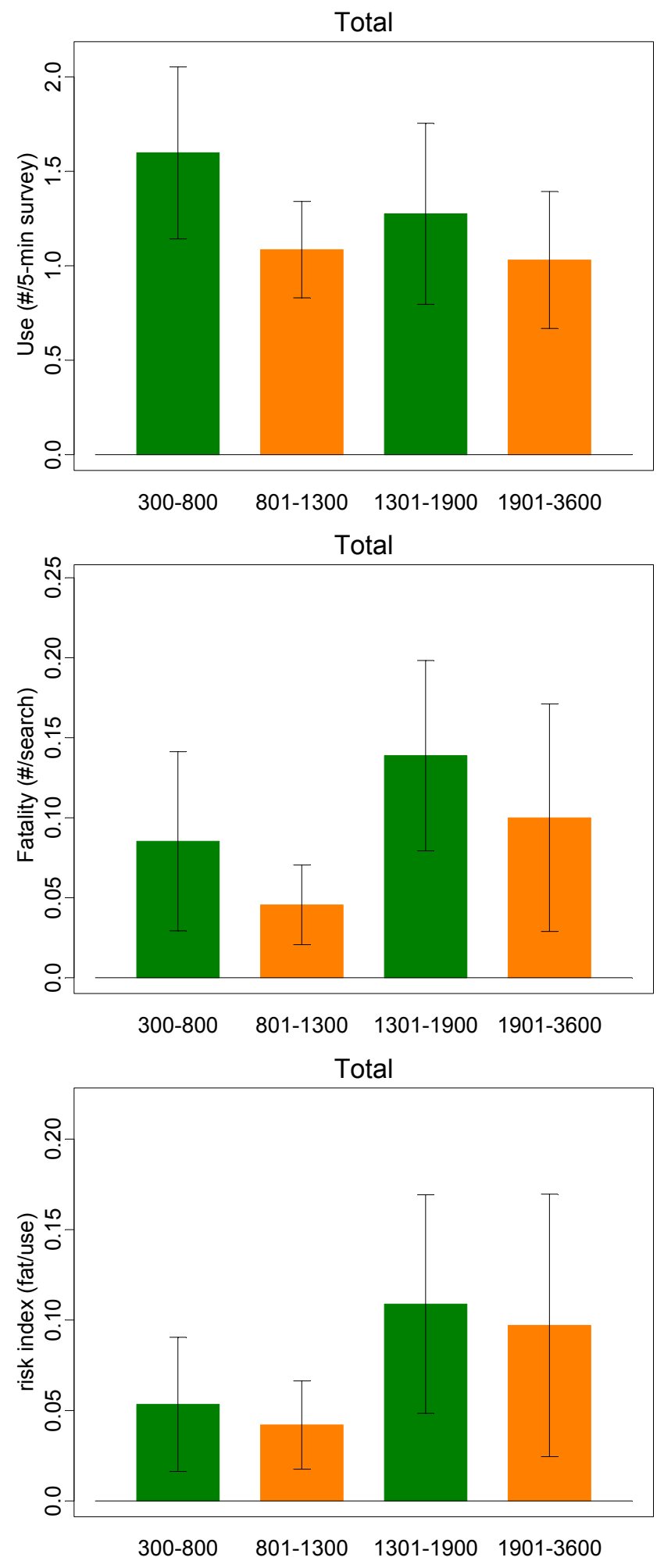

Figure 27. Total birds mean use, fatality rate, and the risk indices by total rotor swept area of search plot observed during Phase I studies at Tehachapi Pass, Wind Resource Area, 2 October 1996 to 27 May 1998, mean use calculated based on observations within $200 \mathrm{~m}$ of site center 

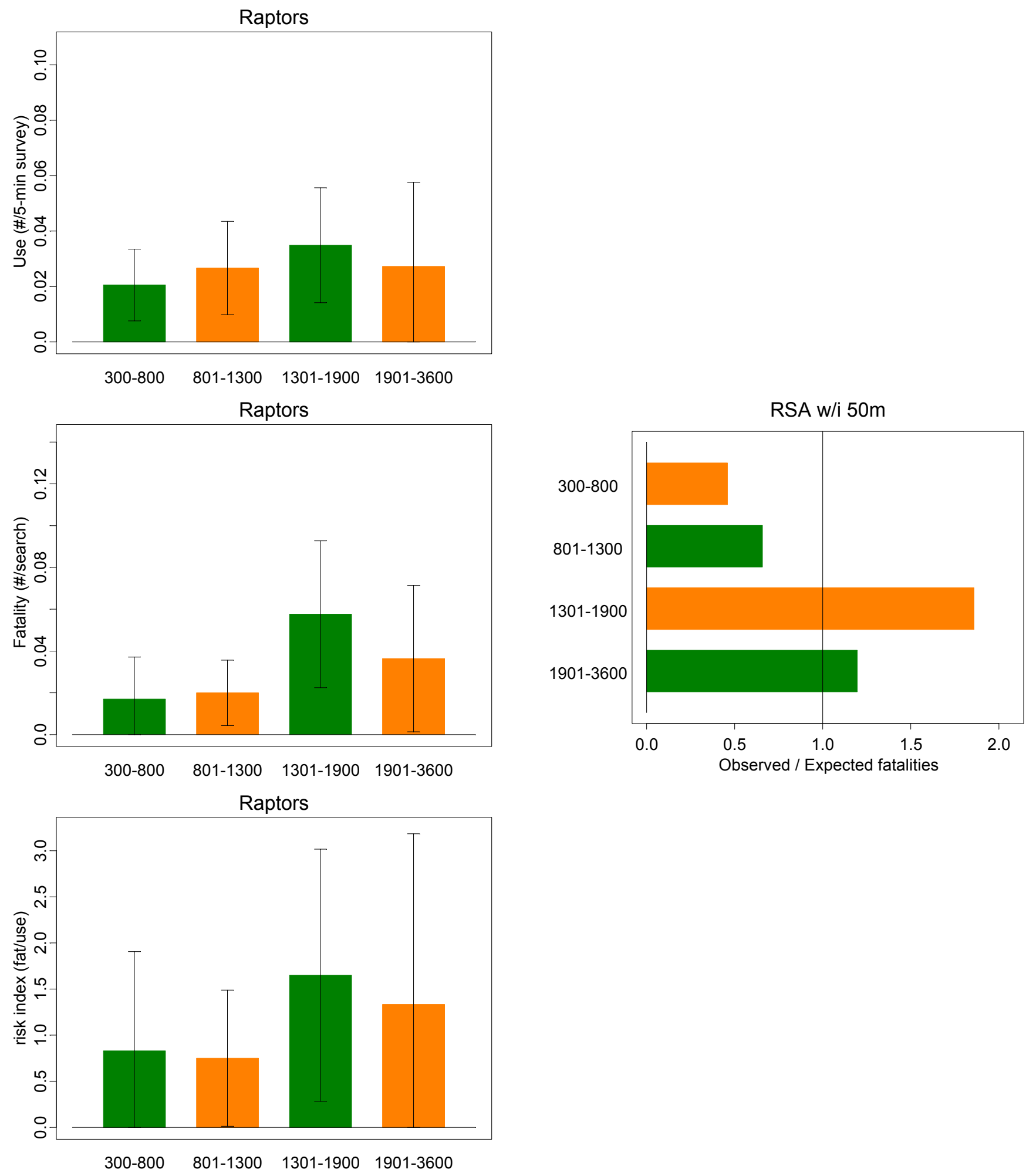

Figure 28. Raptor mean use, fatality rate, observed/expected fatalities, and the risk indices by total rotor swept area of search plot observed during Phase I studies at Tehachapi Pass, Wind Resource Area, 2 October 1996 to 27 May 1998, mean use calculated based on observations within $200 \mathrm{~m}$ of site center 


\section{Appendix}

\section{Appendix A. List of Birds Observed During This Study at Tehachapi Pass Wind Resource Area, 2 October 1996 to 27 May 1998}

Taxonomic Group Common Name

Raptors

Northern Harrier

Sharp-shinned Hawk

Red-tailed Hawk

Ferruginous Hawk

Golden Eagle

Prairie Falcon

American Kestrel

\section{Corvids}

Scrub Jay

Common Raven

Passerines
Scientific Name

Circus cyaneus

Accipter striatus

Buteo jamaicensis

Buteo regalis

Aquila chrysaetos

Falco mexicanus

Falco sparverius

Aphelocoma californica

Corvus corax

Tyrannus verticalis

Western Kingbird

Horned Lark

European Starling

Western Meadowlark

Brewer's Blackbird

House Finch

Lark Sparrow

White-Crowned Sparrow

Dark-Eyed Junco

Black-Throated Sparrow

Sage Sparrow

Rufous-Crowned Sparrow

California Towhee

Cliff Swallow

Loggerhead Shrike

Yellow-Rumped Warbler

Yellow-Breasted Chat

Northern Mockingbird

Cactus Wren

Rock Wren

Bewick's Wren

Plain Titmouse

American Robin

Western Bluebird

Unidentified Hummingbird

Unidentified Swift
Eremophila alpestris

Sturnus vulgaris

Sturnella neglecta

Euphagus cyanocephalus

Carpodacus mexicanus

Chondestes grammacus

Zonotrichia leucophrys

Junco hyemalis

Amphispiza bilineata

Amphispiza belli

Aimophila ruficeps

Pipilo crissalis

Petrochelidon pyrrhonota

Lanius ludovicianus

Dendroica coronata

Icteria virens

Mimus polyglottos

Campylorhynchus brunneicapillus

Salpinctes obsoletus

Thryomanes bewickii

Baeolophus inornatus

Turdus migratorius

Sialia mexicana 
Appendix A (continued)

\begin{tabular}{cll}
\hline Taxonomic Group & Common Name & Scientific Name \\
\hline Other & Unidentified Duck & \\
& Band-Tailed Pigeon & Columba fasciata \\
Rock Dove & Columba livia \\
Mourning Dove & Zenaida macroura \\
California Quail & Callipepla californica \\
Chukar & Alectoris chukar \\
Turkey Vulture & Cathartes aura \\
Greater Roadrunner & Geococcyx californianus \\
Downy Woodpecker & Picoides pubescens \\
Ladder-Backed Woodpecker & Picoides scalaris \\
Nuttall's Woodpecker & Picoides nuttallii \\
Red-Shafted Flicker & Colaptes auratus \\
\hline
\end{tabular}


Appendix B. Fatalities found during carcass searches at Tehachapi Pass Wind Resource Area, 2 October 1996 to 27 May 1998. LLT = large lattice turbine; LTT = large tubular turbine; slt = small lattice turbine; stt = small tubular turbine; VAT = twoblade vertical axis turbine; $w w=$ small windwall turbine

\begin{tabular}{|c|c|c|c|c|c|c|c|}
\hline Species & $\begin{array}{l}\text { Geographic } \\
\text { Location }\end{array}$ & Site $^{a}$ & Date & Condition & $\begin{array}{l}\text { Distance } \\
\text { from } \\
\text { closest } \\
\text { turbine }(\mathrm{m}) \\
\end{array}$ & $\begin{array}{l}\text { Closest } \\
\text { Structure }\end{array}$ & Comments \\
\hline $\begin{array}{l}\text { Unidentified } \\
\text { Passerine }\end{array}$ & East Slope & S02 & $10 / 2 / 96$ & Feather spot & 29 & LTT & $\begin{array}{l}\text { Many grey/brown fthrs. Approx } 5 \\
\text { brown/grey flght fthrs w/ thin white fringe. }\end{array}$ \\
\hline $\begin{array}{l}\text { Red-Tailed } \\
\text { Hawk }\end{array}$ & West Ridge & & $10 / 4 / 96$ & Dismembered & 11 & ww & $\begin{array}{l}\text { Strong odor. flies on body. upper body } \\
\text { gone. fthrs, bone, \& dry flesh remain. }\end{array}$ \\
\hline $\begin{array}{l}\text { Common } \\
\text { Barn Owl }\end{array}$ & East Slope & S04 & $10 / 7 / 96$ & Feather spot & 23 & stt & $\begin{array}{l}\text { Feathers scattered over area } 23 \mathrm{~m} @ 334 \\
\text { deg. from E13. }\end{array}$ \\
\hline $\begin{array}{l}\text { Unidentified } \\
\text { Passerine }\end{array}$ & West Ridge & $\mathrm{ZO3}$ & $10 / 8 / 96$ & Feather spot & 19 & slt & $\begin{array}{l}\text { Estimated time since death. ( }>100 \text { body } \\
\text { feathers } \&>15 \text { flight feathers). }\end{array}$ \\
\hline Rock Dove & West Ridge & $\mathrm{ZO3}$ & $10 / 8 / 96$ & Feather spot & 9 & sit & $\begin{array}{l}12 \text { Feather dispersed along top }(1.5 \mathrm{~m} \\
\text { high) of dirt rd side brim; along } 3-\mathrm{m} \text { area. }\end{array}$ \\
\hline Chukar & Middle Ridge & $\mathrm{CO3}$ & $10 / 8 / 96$ & Feather spot & 15 & $\mathrm{stt}$ & $\begin{array}{l}\text { Numerous feathers found scattered over } \\
\text { approx. a } 15-m^{2} \text { area.. }\end{array}$ \\
\hline $\begin{array}{l}\text { Red-Tailed } \\
\text { Hawk }\end{array}$ & West Ridge & & $10 / 14 / 96$ & Feather spot & 13 & LLT & $\begin{array}{l}\text { Found } 14 \mathrm{~m} \text { from } 32-4 \text { between in } \& 32-3 \text {. } \\
\text { Coll. } 2 \text { blood and many body feathers. }\end{array}$ \\
\hline Rock Wren & West Ridge & Z18 & $10 / 29 / 96$ & Feather spot & 10 & ww & $\begin{array}{l}\text { Found } 15 \text { remiges and } 10 \text { downy feathers } \\
\text { in a shrub while looking for fat. \#8. }\end{array}$ \\
\hline $\begin{array}{l}\text { American } \\
\text { Kestrel }\end{array}$ & West Ridge & Z18 & $10 / 29 / 96$ & Feather spot & 12 & ww & $\begin{array}{l}\text { Found } 10 \text { tail feathers and several body } \\
\text { feathers on ledge east of } 4-36 \& 4-37 \text {. }\end{array}$ \\
\hline $\begin{array}{l}\text { Great Horned } \\
\text { Owl }\end{array}$ & West Ridge & Z18 & $10 / 29 / 96$ & $\begin{array}{l}\text { Feather spot } \\
\text { and/or bones }\end{array}$ & 0 & ww & $\begin{array}{l}\text { Found many wing \& body feathers around } \\
\text { the bases of } 4-35,4-36, \& 4-37 \text {. }\end{array}$ \\
\hline $\begin{array}{l}\text { Red-Tailed } \\
\text { Hawk }\end{array}$ & West Ridge & Z48 & $11 / 1 / 96$ & Feather spot & 5 & LLT & $\begin{array}{l}\text { Feathers w/in } 50 \mathrm{~m} \text { radius of perm. Study } \\
\text { site } Z 48 \text { as was found on } 2 / 11 / 97 \text { \& } \\
8 / 28 / 97 \text {. }\end{array}$ \\
\hline $\begin{array}{l}\text { Common } \\
\text { Raven }\end{array}$ & Middle Ridge & $\mathrm{C} 22$ & $11 / 4 / 96$ & Feather spot & 46 & distribution line & $\begin{array}{l}\text { Feather spot (approx. }>25 \text { flight feathers), } \\
\text { area about } 3 \mathrm{~m} \times 4 \mathrm{~m} \text {. }\end{array}$ \\
\hline $\begin{array}{l}\text { Great Horned } \\
\text { Owl }\end{array}$ & Middle Ridge & $\mathrm{C} 21$ & $11 / 4 / 96$ & $\begin{array}{l}\text { Feather spot } \\
\text { and/or bones }\end{array}$ & 50 & $\mathrm{stt}$ & $\begin{array}{l}\text { Feather spot approx. } 1 \mathrm{~m}^{2} \text { (approx. } 30 \\
\text { flight feathers \& } 1 \text { bone fragment). } 50 \mathrm{~m} \\
\text { @ } 256 \text { deg. from } 9-20 \mathrm{~B} \text {. }\end{array}$ \\
\hline
\end{tabular}




\begin{tabular}{|c|c|c|c|c|c|c|c|}
\hline Species & $\begin{array}{l}\text { Geographic } \\
\text { Location }\end{array}$ & Site $^{a}$ & Date & Condition & $\begin{array}{l}\text { Distance } \\
\text { from } \\
\text { closest } \\
\text { turbine }(\mathrm{m})\end{array}$ & $\begin{array}{l}\text { Closest } \\
\text { Structure }\end{array}$ & Comments \\
\hline $\begin{array}{l}\text { Red-Shafted } \\
\text { Flicker }\end{array}$ & West Ridge & $\mathrm{Z} 22$ & $11 / 6 / 96$ & Feather spot & 20 & ww & Many feathers. \\
\hline $\begin{array}{l}\text { Red-Tailed } \\
\text { Hawk }\end{array}$ & East Slope & S03 & $11 / 14 / 96$ & Dismembered & 11 & LTT & $\begin{array}{l}\text { Fresh kill a day or } 2 \text { at most. Head } \& \text { Ift } \\
\text { wing sheared off. }\end{array}$ \\
\hline $\begin{array}{l}\text { White- } \\
\text { Crowned } \\
\text { Sparrow }\end{array}$ & Middle Ridge & & $11 / 15 / 96$ & Intact & 35 & $\begin{array}{l}\text { other human- } \\
\text { made structure }\end{array}$ & $\begin{array}{l}\text { Cannon maint. office. Body fresh \& } \\
\text { somewhat warm. Possibly slammed into } \\
\text { building. }\end{array}$ \\
\hline $\begin{array}{l}\text { Dark-Eyed } \\
\text { Junco }\end{array}$ & Middle Ridge & C16 & $12 / 2 / 96$ & Intact & 49 & distribution line & $\begin{array}{l}\text { Carcass shows no signs of trauma, but } \\
\text { numerous small feathers on buckwheat } \\
\text { found. }\end{array}$ \\
\hline $\begin{array}{l}\text { Western } \\
\text { Meadowlark }\end{array}$ & Middle Ridge & C39 & $1 / 23 / 97$ & Feather spot & 14 & stt & $\begin{array}{l}\text { Fthr spot of aprox. } 1 \mathrm{~m}^{2} \text { area; }>30 \text { flt. } \\
\text { fthers, }>100 \text { body fthers. }\end{array}$ \\
\hline $\begin{array}{l}\text { Unidentified } \\
\text { Bird }\end{array}$ & West Ridge & Z42 & $1 / 29 / 97$ & $\begin{array}{l}\text { Feather spot } \\
\text { and/or bones }\end{array}$ & 1 & LLT & $\begin{array}{l}45 \mathrm{~m} \text { from study center } 22-7 \text { LLT. One } \\
\text { femur and } 2 \text { tibiotarsus. }\end{array}$ \\
\hline $\begin{array}{l}\text { Unidentified } \\
\text { Bird }\end{array}$ & West Ridge & $\mathrm{Z50}$ & $2 / 5 / 97$ & Intact & 5 & sit & $\begin{array}{l}\text { Flght fthrs and partial skeleton (see data } \\
\text { sheet). Fthrs weathered. } 12-31-97 \text {. }\end{array}$ \\
\hline $\begin{array}{l}\text { Red-Tailed } \\
\text { Hawk }\end{array}$ & West Ridge & $\mathrm{Z52}$ & $2 / 21 / 97$ & Feather spot & 40 & WW & $\begin{array}{l}\text { Found some feathers within and some } \\
\text { outside the search site. }\end{array}$ \\
\hline $\begin{array}{l}\text { Great Horned } \\
\text { Owl }\end{array}$ & West Ridge & $\mathrm{Z60}$ & $2 / 24 / 97$ & Feather spot & 2 & ww & $\begin{array}{l}\text { Cursory search. One fthr collected for } \\
\text { species verification. Numerous widely } \\
\text { scattered fthrs. }\end{array}$ \\
\hline
\end{tabular}




\begin{tabular}{|c|c|c|c|c|c|c|c|}
\hline Species & $\begin{array}{l}\text { Geographic } \\
\text { Location }\end{array}$ & Site $^{a}$ & Date & Condition & $\begin{array}{l}\text { Distance } \\
\text { from } \\
\text { closest } \\
\text { turbine }(\mathrm{m})\end{array}$ & $\begin{array}{l}\text { Closest } \\
\text { Structure }\end{array}$ & Comments \\
\hline $\begin{array}{l}\text { Unidentified } \\
\text { Bird }\end{array}$ & West Ridge & Z14 & $3 / 24 / 97$ & $\begin{array}{l}\text { Feather spot } \\
\text { and/or bones }\end{array}$ & 7 & LLT & $\begin{array}{l}\text { Found legs, pelvic bone and a few ribs. } \\
\text { Old \& weathered. }\end{array}$ \\
\hline Chukar & Middle Ridge & C17 & $3 / 27 / 97$ & Dismembered & 37 & distribution line & $\begin{array}{l}\text { Rt. wing, loose wing, tail, \& body feathers. } \\
\text { Fatality may have been recent. }\end{array}$ \\
\hline $\begin{array}{l}\text { Red-Tailed } \\
\text { Hawk }\end{array}$ & West Ridge & $\mathrm{Z21}$ & $4 / 1 / 97$ & $\begin{array}{l}\text { Feather spot } \\
\text { and/or bones }\end{array}$ & 4 & LLT & 2 bone frags. \\
\hline $\begin{array}{l}\text { Loggerhead } \\
\text { Shrike }\end{array}$ & Middle Rid & $\operatorname{lge}^{2}$ & $4 / 14 / 97$ & Intact & 350 & $\begin{array}{c}\text { main road }>35 \\
\mathrm{mph}\end{array}$ & $\begin{array}{l}\text { Bird was hit by a vehicle at } 20 \mathrm{mph} \\
\text { coming down Cannon main entrance road. }\end{array}$ \\
\hline $\begin{array}{l}\text { Red-Shafted } \\
\text { Flicker }\end{array}$ & Middle Ridge & $\mathrm{C} 25 \mathrm{~B}$ & $5 / 13 / 97$ & Feather spot & 1 & VAT & Found body fthrs \& several retrices. \\
\hline $\begin{array}{l}\text { Mourning } \\
\text { Dove }\end{array}$ & East Slope & S39 & $5 / 28 / 97$ & Feather spot & 17 & $\begin{array}{l}\text { other human- } \\
\text { made structure }\end{array}$ & $\begin{array}{l}\text { Clusters of feathers found over square } \\
\text { meter area. Some still had skin attached. }\end{array}$ \\
\hline $\begin{array}{l}\text { Common } \\
\text { Raven }^{3}\end{array}$ & West Ridge & & $6 / 3 / 97$ & Intact & 15 & $\begin{array}{l}\text { main road }>35 \\
\mathrm{mph}\end{array}$ & $\begin{array}{l}\text { Found alongside main road, broken } \\
\text { tailbone, no leg func, taken to rehab, died } \\
6 / 5 / 97 \text {. }\end{array}$ \\
\hline $\begin{array}{l}\text { Great Horned } \\
\text { Owl }\end{array}$ & East Slope & S42 & $6 / 9 / 97$ & Feather spot & 30 & stt & $\begin{array}{l}\text { Group of primaries stuck together; several } \\
\text { other wing feathers only had shafts left. }\end{array}$ \\
\hline $\begin{array}{l}\text { Unidentified } \\
\text { Passerine }\end{array}$ & West Ridge & Z44 & $6 / 13 / 97$ & Feather spot & 38 & sit & $\begin{array}{l}\text { Scattered fthrs ( } 8 \times 1 \mathrm{~m} \text { area }) \text { in veg. } \\
\text { along dirt road. }\end{array}$ \\
\hline
\end{tabular}




\begin{tabular}{|c|c|c|c|c|c|c|c|}
\hline Species & $\begin{array}{l}\text { Geographic } \\
\text { Location }\end{array}$ & Site $^{a}$ & Date & Condition & $\begin{array}{l}\text { Distance } \\
\text { from } \\
\text { closest } \\
\text { turbine }(\mathrm{m})\end{array}$ & $\begin{array}{l}\text { Closest } \\
\text { Structure }\end{array}$ & Comments \\
\hline $\begin{array}{l}\text { Mourning } \\
\text { Dove }\end{array}$ & Middle Ridge & C48 & $6 / 17 / 97$ & Feather spot & 6 & stt & $\begin{array}{l}\text { Found } 50+\text { feathers, mostly along side of } \\
\text { rd. or on rd. berm. Appears semi-recently } \\
\text { graded. }\end{array}$ \\
\hline $\begin{array}{l}\text { Western } \\
\text { Meadowlark }\end{array}$ & West Ridge & Z06 & $7 / 10 / 97$ & $\begin{array}{l}\text { Feather spot } \\
\text { and/or bones }\end{array}$ & 11 & sit & $\begin{array}{l}\text { Found frag. of head and feathers } \\
\text { alongside some breast skin-had yell. } \\
\text { feath. }\end{array}$ \\
\hline $\begin{array}{l}\text { Red-Tailed } \\
\text { Hawk }\end{array}$ & West Ridge & & $7 / 14 / 97$ & Feather spot & 20 & slt & $\begin{array}{l}\text { Feathers along both sides of road at about } \\
307 \text { deg. from V136. Feathers fresh. }\end{array}$ \\
\hline $\begin{array}{l}\text { American } \\
\text { Kestrel }\end{array}$ & West Ridge & & $7 / 16 / 97$ & Feather spot & 40 & sit & $\begin{array}{l}9 \text { L. Wing feathers and several body } \\
\text { feathers (good cond.) } 54 \mathrm{~m} \text { from site } \mathrm{Z} 12 \\
\text { (V102 at } 336 \text { deg). }\end{array}$ \\
\hline $\begin{array}{l}\text { Red-Tailed } \\
\text { Hawk }\end{array}$ & West Ridge & $\mathrm{Z17}$ & $7 / 18 / 97$ & Dismembered & 9 & LLT & $\begin{array}{l}\text { Found rt. wing, fthr spot, and pelvis \& } 2 \\
\text { partial legs in } 3 \text { places \& fthrs. Scattered } \\
\text { in area. }\end{array}$ \\
\hline $\begin{array}{l}\text { California } \\
\text { Quail } \\
\end{array}$ & Middle Ridge & $\mathrm{C} 23$ & $7 / 24 / 97$ & Feather spot & 36 & $\begin{array}{c}\text { transmission } \\
\text { line }\end{array}$ & $\begin{array}{l}\text { Found fether spot; }>50 \text { feathers in a } 10 X \\
5 \text { area } 36 \mathrm{~m} \text { from site turb. }\end{array}$ \\
\hline $\begin{array}{l}\text { Unidentified } \\
\text { Bird }\end{array}$ & West Ridge & Z66 & $7 / 29 / 97$ & $\begin{array}{l}\text { Feather spot } \\
\text { and/or bones }\end{array}$ & 7 & LLT & $\begin{array}{l}\text { Found talons- tried to ID spp..Might be } \\
\text { ACCI or PRFA. Also leg bones. }\end{array}$ \\
\hline $\begin{array}{l}\text { Unidentified } \\
\text { Bird }\end{array}$ & West Ridge & $\mathrm{Z64}$ & $8 / 6 / 97$ & $\begin{array}{l}\text { Feather spot } \\
\text { and/or bones }\end{array}$ & 49 & LLT & Found 1 humerus and 2 bone frags. \\
\hline $\begin{array}{l}\text { Common } \\
\text { Raven }\end{array}$ & West Ridge & & $8 / 8 / 97$ & Feather spot & 19 & WW & $\begin{array}{l}\text { About } 19 \mathrm{~m} \text { from turb. } 19-5 \text {. Found about } \\
20 \text { remiges and some body feathers. }\end{array}$ \\
\hline $\begin{array}{l}\text { Unidentified } \\
\text { Bird }\end{array}$ & West Ridge & $\mathrm{Z} 27$ & $8 / 12 / 97$ & $\begin{array}{l}\text { Feather spot } \\
\text { and/or bones }\end{array}$ & 36 & $\begin{array}{l}\text { transmission } \\
\text { line }\end{array}$ & $\begin{array}{l}\text { Compared bones to GHOW-looks more } \\
\text { like RTHA. Found coracoid, humerus, } \\
\text { tibiotarsus. Also found tattered feathers. }\end{array}$ \\
\hline $\begin{array}{l}\text { Long-Eared } \\
\text { Bat }\end{array}$ & West Ridge & $\mathrm{Z} 23$ & $8 / 12 / 97$ & Intact & 3 & sitt & Found w/ fresh wound. \\
\hline $\begin{array}{l}\text { Great Horned } \\
\text { Owl }\end{array}$ & West Ridge & $\mathrm{Z28}$ & $8 / 13 / 97$ & Feather spot & 3 & ww & $\begin{array}{l}\text { Feathers were around base of 6-43.Mostly } \\
\text { body and down feathers. }\end{array}$ \\
\hline $\begin{array}{l}\text { Mourning } \\
\text { Dove }\end{array}$ & East Slope & $S 26$ & $8 / 18 / 97$ & Feather spot & 38 & fence & $\begin{array}{l}\text { Found feather spot 38M @ } 120 \text { deg. from } \\
\text { turb. K1. }\end{array}$ \\
\hline
\end{tabular}




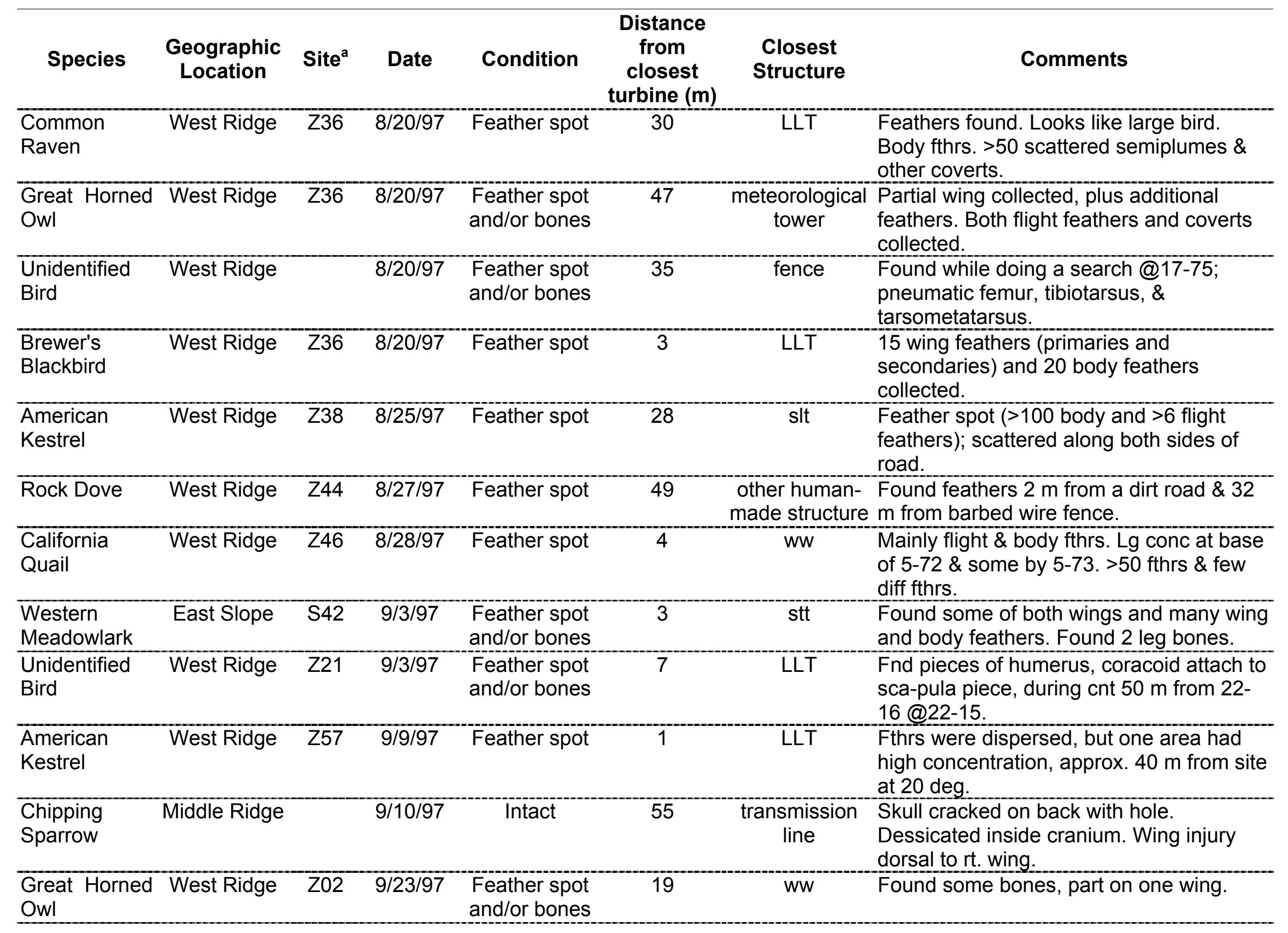




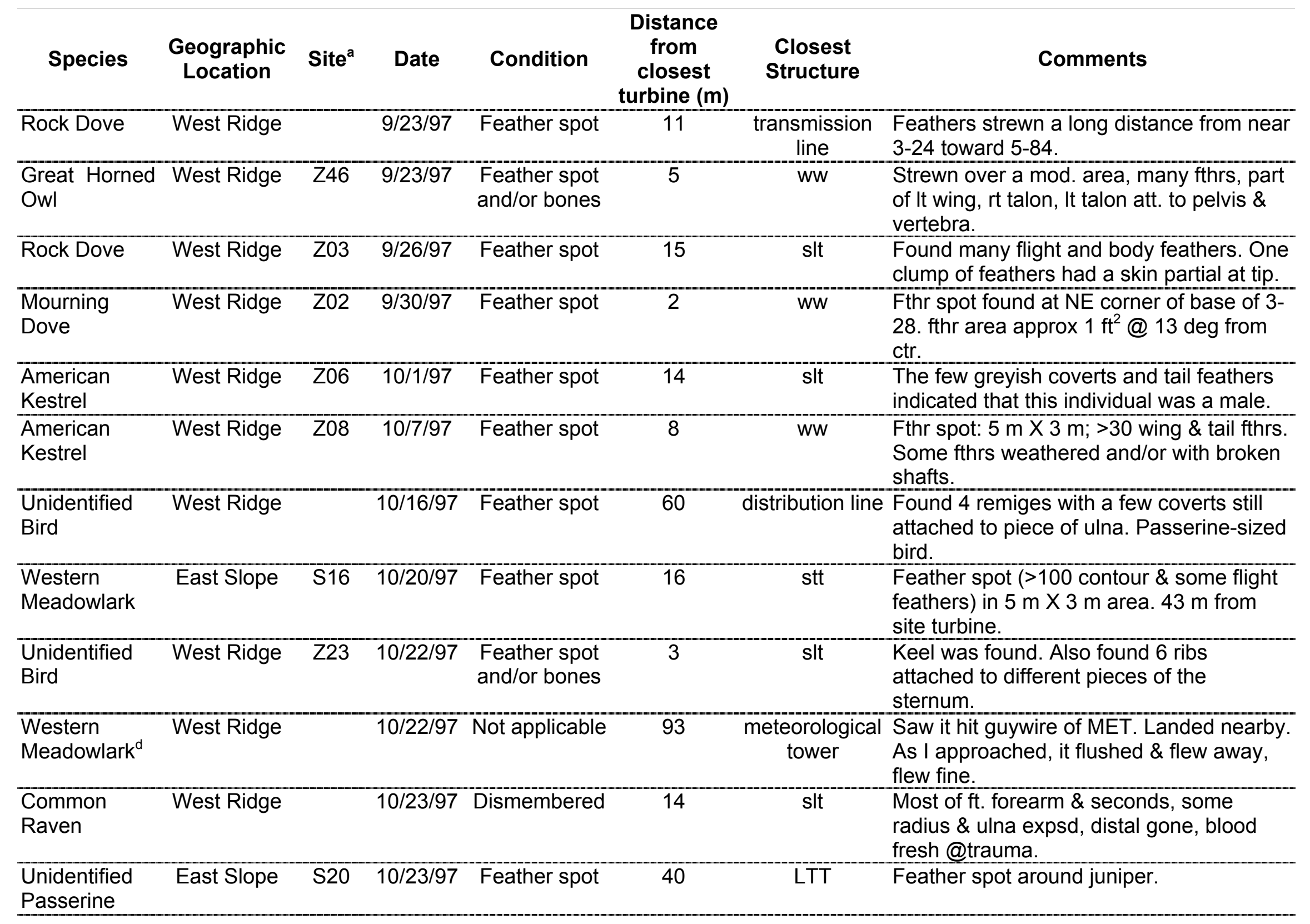




\begin{tabular}{|c|c|c|c|c|c|c|c|}
\hline Species & $\begin{array}{l}\text { Geographic } \\
\text { Location }\end{array}$ & Site $^{a}$ & Date & Condition & $\begin{array}{l}\text { Distance } \\
\text { from } \\
\text { closest } \\
\text { turbine }(\mathrm{m})\end{array}$ & $\begin{array}{l}\text { Closest } \\
\text { Structure }\end{array}$ & Comments \\
\hline Hermit Thrush & West Ridge & & $10 / 24 / 97$ & Intact & 15 & $\begin{array}{l}\text { other human- } \\
\text { made structure }\end{array}$ & $\begin{array}{l}\text { Fresh kill, blood was fresh and neck was } \\
\text { loose. Eyes are gone. }\end{array}$ \\
\hline $\begin{array}{l}\text { Common } \\
\text { Raven }\end{array}$ & West Ridge & Z58 & $10 / 28 / 97$ & Feather spot & 0 & ww & $\begin{array}{l}\text { Found several body and flt feathers in } \\
\text { area around site Z58; main clump } 41 \mathrm{~m} \\
\text { from } 17-46 \text {. }\end{array}$ \\
\hline $\begin{array}{l}\text { Unidentified } \\
\text { Bird }\end{array}$ & East Slope & S21 & $10 / 28 / 97$ & $\begin{array}{l}\text { Feather spot } \\
\text { and/or bones }\end{array}$ & 30 & LTT & $\begin{array}{l}\text { Bone has marks as if sm mammal had } \\
\text { gnawed on it. }\end{array}$ \\
\hline Rock Dove & West Ridge & $\mathrm{ZO3}$ & $10 / 30 / 97$ & Feather spot & 3 & sit & $\begin{array}{l}\text { Feathers spread from } 3 \mathrm{~m} \text { away from } \\
\text { turbine to } 35 \mathrm{~m} \text { away. Found during util } \\
\text { count. }\end{array}$ \\
\hline $\begin{array}{l}\text { Flammulated } \\
\text { Owl }\end{array}$ & West Ridge & $\mathrm{Z70}$ & $10 / 30 / 97$ & Feather spot & 10 & slt & $\begin{array}{l}\text { Fthrs collected }=100+\text { (includes } 12+ \\
\text { remiges })\end{array}$ \\
\hline $\begin{array}{l}\text { Red-Tailed } \\
\text { Hawk }\end{array}$ & West Ridge & Z33 & $10 / 31 / 97$ & Dismembered & 14 & LLT & $\begin{array}{l}\text { Coll pair of wings and other fthrs. Flesh on } \\
\text { wings vry fresh, wings flex., torso } \\
\text { devoured. }\end{array}$ \\
\hline $\begin{array}{l}\text { Dark-Eyed } \\
\text { Junco }\end{array}$ & Middle Ridge & & $11 / 6 / 97$ & Feather spot & 59 & $\begin{array}{l}\text { meteorological } \\
\text { tower }\end{array}$ & $\begin{array}{l}\text { Found sev. flt. and body fthrs } 59 \mathrm{~m} \text { from } \\
\text { site C62 \& } 9 \mathrm{~m} \text { from guywire of MET - } \\
\text { likely coll. }\end{array}$ \\
\hline
\end{tabular}




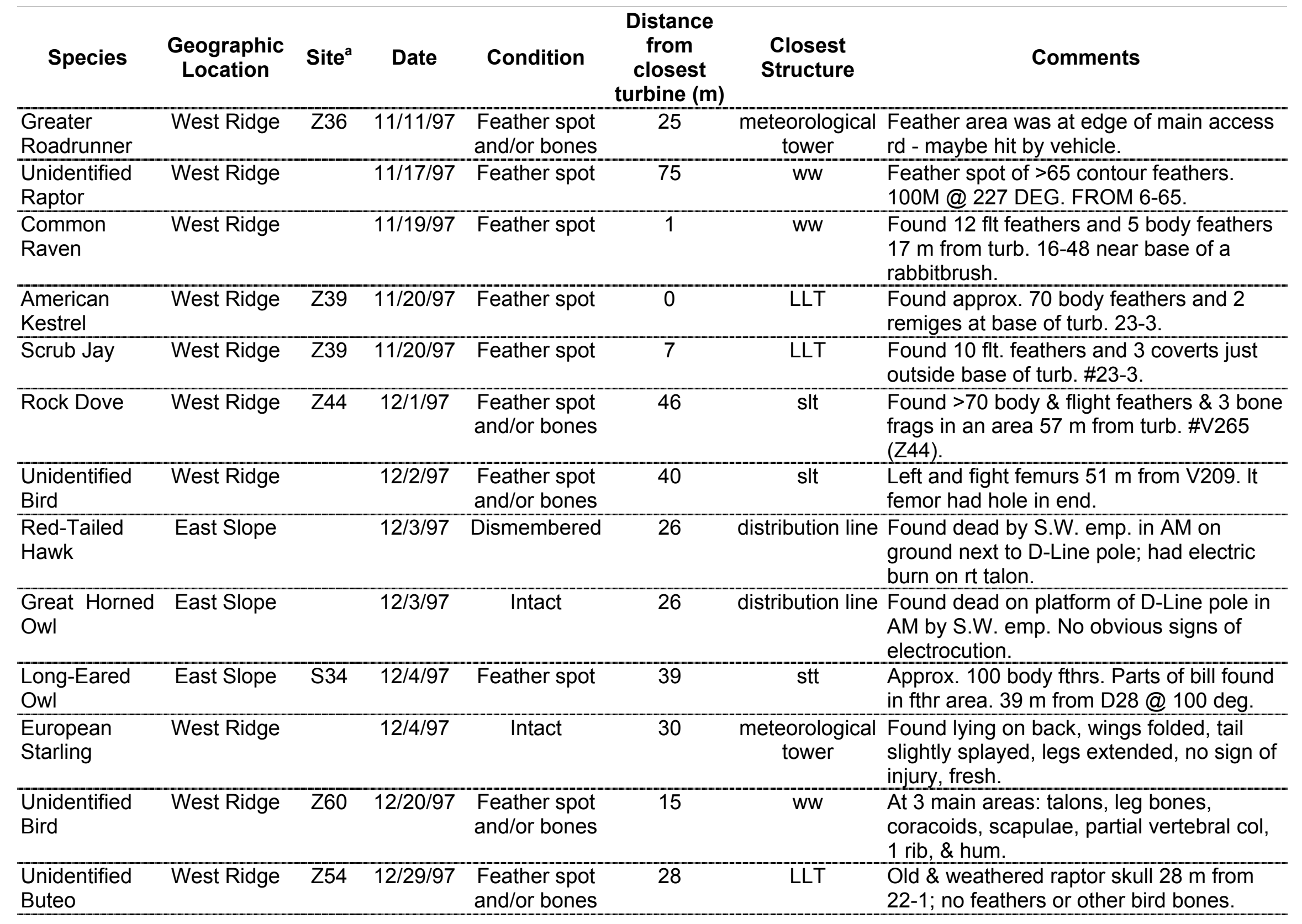




\begin{tabular}{|c|c|c|c|c|c|c|c|}
\hline Species & $\begin{array}{l}\text { Geographic } \\
\text { Location }\end{array}$ & Site $^{a}$ & Date & Condition & $\begin{array}{l}\text { Distance } \\
\text { from } \\
\text { closest } \\
\text { turbine }(\mathrm{m})\end{array}$ & $\begin{array}{l}\text { Closest } \\
\text { Structure }\end{array}$ & Comments \\
\hline $\begin{array}{l}\text { American } \\
\text { Kestrel }\end{array}$ & West Ridge & Z63 & $12 / 31 / 97$ & Feather spot & 3 & ww & $\begin{array}{l}\text { Found at least } 20 \text { (probably more) body } \\
\text { fthrs around base of } 5-116 \text {. }\end{array}$ \\
\hline Horned Lark & East Slope & S02 & $1 / 6 / 98$ & Feather spot & 18 & LTT & $\begin{array}{l}>500 \text { body \& flt. fthrs in } 1 \text { large fthr spot, } \\
\text { some may still be there. }\end{array}$ \\
\hline $\begin{array}{l}\text { Red-Tailed } \\
\text { Hawk }\end{array}$ & East Slope & S05 & $1 / 6 / 98$ & Feather spot & 12 & LTT & $\begin{array}{l}\text { Found } 7 \text { remiges, } 14 \text { add'l wing coverts } \\
\text { and a few body fthrs. Several remiges - } \\
\text { broken tips. }\end{array}$ \\
\hline $\begin{array}{l}\text { Mourning } \\
\text { Dove }\end{array}$ & West Ridge & $\mathrm{Z12}$ & $1 / 21 / 98$ & Feather spot & 31 & slt & $\begin{array}{l}5 \text { Right remiges (probably all primaries) \& } \\
7 \text { small UNID fthrs collected. }\end{array}$ \\
\hline Rock Dove & West Ridge & $\mathrm{Z} 65$ & $1 / 26 / 98$ & Feather spot & 46 & telephone line & $\begin{array}{l}28 \text { weathered flight fthrs (includes } \\
\text { remiges, retrices, } \&<5 \text { coverts). }\end{array}$ \\
\hline $\begin{array}{l}\text { Red-Tailed } \\
\text { Hawk }\end{array}$ & West Ridge & & $1 / 27 / 98$ & Dismembered & 10 & ww & $\begin{array}{l}\text { Pair of wings \& adult rufous tail. Gnawed } \\
\text { bones. Flexible skin w/ sticky, very red } \\
\text { blood. }\end{array}$ \\
\hline $\begin{array}{l}\text { Great Horned } \\
\text { Owl }\end{array}$ & East Slope & S16 & $2 / 5 / 98$ & Feather spot & 47 & distribution line & $\begin{array}{l}4 \text { remiges from same wing. Also found } 2 \\
\text { smaller fthrs. } 2 \text { pieces of fthrs, and } 1 \\
\text { rachis tip. }\end{array}$ \\
\hline $\begin{array}{l}\text { Greater } \\
\text { Roadrunner }\end{array}$ & East Slope & S17 & $2 / 5 / 98$ & Feather spot & 41 & LTT & $\begin{array}{l}\text { Approx } 100 \text { fthrs, inc. } 8 \text { retrices, } 22 \\
\text { remiges, and numerous wing coverts \& } \\
\text { contour fthrs. }\end{array}$ \\
\hline
\end{tabular}




\begin{tabular}{|c|c|c|c|c|c|c|c|}
\hline Species & $\begin{array}{l}\text { Geographic } \\
\text { Location }\end{array}$ & Site $^{a}$ & Date & Condition & $\begin{array}{l}\text { Distance } \\
\text { from } \\
\text { closest } \\
\text { turbine }(\mathrm{m})\end{array}$ & $\begin{array}{l}\text { Closest } \\
\text { Structure }\end{array}$ & Comments \\
\hline $\begin{array}{l}\text { Red-Tailed } \\
\text { Hawk }\end{array}$ & West Ridge & $\mathrm{Z} 23$ & $2 / 27 / 98$ & Dismembered & 13 & sit & $\begin{array}{l}\text { Found femur, tibiot, It wing, ruf. tail fthrs. } \\
\text { may have missed some fthrs. prob scav } \\
\text { by birds. }\end{array}$ \\
\hline Horned Lark & West Ridge & $\mathrm{Z30}$ & $3 / 4 / 98$ & $\begin{array}{l}\text { Feather spot } \\
\text { and/or bones }\end{array}$ & 17 & LLT & $\begin{array}{l}\text { Approx } 50 \text { contour feathers } \& 7 \text { brown } \\
\text { remiges. }\end{array}$ \\
\hline $\begin{array}{l}\text { Unidentified } \\
\text { Bird }\end{array}$ & West Ridge & Z33 & $3 / 4 / 98$ & $\begin{array}{l}\text { Feather spot } \\
\text { and/or bones }\end{array}$ & 26 & LLT & $\begin{array}{l}7 \text { wthered remiges att., } 11 \text { brkn shfts of } \\
\text { remiges att. to hum. w/ ends of coracoid \& } \\
\text { scapula att. }\end{array}$ \\
\hline $\begin{array}{l}\text { Unidentified } \\
\text { Sparrow }\end{array}$ & West Ridge & Z37 & $3 / 11 / 98$ & Feather spot & 17 & ww & $\begin{array}{l}>100 \text { body feathers (many downy) \& } \\
\text { approx } 12 \text { remiges. }\end{array}$ \\
\hline $\begin{array}{l}\text { American } \\
\text { Kestrel }\end{array}$ & West Ridge & Z36 & $3 / 23 / 98$ & Feather spot & 6 & LLT & $\begin{array}{l}\text { Believe most larger fthrs coll, some small } \\
\text { fthrs might still be present. }\end{array}$ \\
\hline $\begin{array}{l}\text { Unidentified } \\
\text { Bird }\end{array}$ & West Ridge & $\mathrm{Z36}$ & $3 / 23 / 98$ & $\begin{array}{l}\text { Feather spot } \\
\text { and/or bones }\end{array}$ & 13 & LLT & Found old humerus, probably from raptor. \\
\hline Prairie Falcon & Middle Ridge & C48 & $3 / 24 / 98$ & Feather spot & 18 & stt & $\begin{array}{l}4 \text { retrices ( } 2 \text { attached together by dried } \\
\text { skin ). Each w/ dried skin at end of each } \\
\text { quill). }\end{array}$ \\
\hline $\begin{array}{l}\text { Unidentified } \\
\text { Bird }\end{array}$ & West Ridge & Z49 & $4 / 9 / 98$ & $\begin{array}{l}\text { Feather spot } \\
\text { and/or bones }\end{array}$ & 46 & wW & $\begin{array}{l}\text { Old bleached sternum (probably RAPT, } \\
\text { possibly GHOW/RTHA). }\end{array}$ \\
\hline $\begin{array}{l}\text { Unidentified } \\
\text { Bird }\end{array}$ & West Ridge & & $4 / 23 / 98$ & $\begin{array}{l}\text { Feather spot } \\
\text { and/or bones }\end{array}$ & 31 & sit & $\begin{array}{l}\text { Fragmented withered bones outside of } \\
\text { search area of site } Z 53 \text {. Prob. at least } 1 \\
\text { humerus or femur. }\end{array}$ \\
\hline $\begin{array}{l}\text { Common } \\
\text { Raven }\end{array}$ & West Ridge & & $4 / 23 / 98$ & Feather spot & 11 & ww & $\begin{array}{l}\text { Feathers old \& withered. About } 15 \text { flt fthrs } \\
\text { (mostly primaries) w/in } 1.5 \text {-m area. Large } \\
\text { black feathers. }\end{array}$ \\
\hline \multicolumn{8}{|c|}{${ }^{a}$ Null value for site indicates fatality found outside of permanent sites. } \\
\hline \multicolumn{8}{|c|}{${ }^{\mathrm{b}}$ West of Sea West - area between Cannon and Sea West. } \\
\hline \multicolumn{8}{|c|}{${ }^{\mathrm{C}}$ Found alive but later died from injuries. } \\
\hline
\end{tabular}




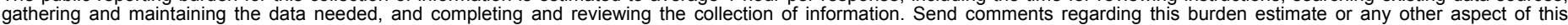

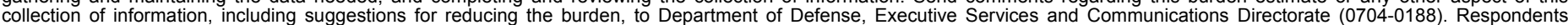

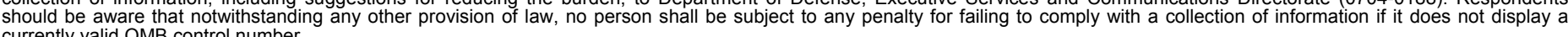

PLEASE DO NOT RETURN YOUR FORM TO THE ABOVE ORGANIZATION.

\section{REPORT DATE (DD-MM-YYYY) \\ September 2004 \\ 2. REPORT TYPE \\ Subcontractor Report}

4. TITLE AND SUBTITLE

Avian Monitoring and Risk Assessment at the Tehachapi Pass Wind Resource Area

ass Wind

6. AUTHOR(S)

R. Anderson, J. Tom, N. Neumann, W.P. Erickson, M.D. Strickland, M. Bourassa, K.J. Bay, and K.J. Sernka
3. DATES COVERED (From - To)

October 2, 1996 - May 27, 1998

5a. CONTRACT NUMBER

DE-AC36-99-GO10337

5b. GRANT NUMBER

5c. PROGRAM ELEMENT NUMBER

5d. PROJECT NUMBER

NREL/SR-500-36416

5e. TASK NUMBER

WER4.7003

5f. WORK UNIT NUMBER

7. PERFORMING ORGANIZATION NAME(S) AND ADDRESS(ES)

State Energy Resources Conservation and Development Commission

Sacramento, CA

Western EcoSystems Technology, Inc.

Cheyenne, Wyoming

9. SPONSORING/MONITORING AGENCY NAME(S) AND ADDRESS(ES)

National Renewable Energy Laboratory

1617 Cole Blvd.

Golden, CO 80401-3393

8. PERFORMING ORGANIZATION
REPORT NUMBER
ZAT-6-15179-02; TAM-7-16454-01

12. DISTRIBUTION AVAILABILITY STATEMENT

National Technical Information Service

U.S. Department of Commerce

5285 Port Royal Road

Springfield, VA 22161

13. SUPPLEMENTARY NOTES

NREL Technical Monitor: Karin Sinclair

14. ABSTRACT (Maximum 200 Words)

Observations of dead raptors at the Altamont Pass Wind Resource Area triggered concerns on the parts of regulatory agencies, environmental/conservation groups, wildlife resource agencies, and wind and electric utility industries about possible impacts to birds from wind energy development. Bird fatality rates observed at most wind projects are not currently considered significant to individual bird species populations. Although many bird species have observed fatalities, raptors have received the most attention. The primary objective of this study was to estimate and compare bird utilization, fatality rates, and collision risk indices among factors such as bird taxonomic groups, turbine types, and turbine locations within the operating wind plant in the Tehachapi Pass WRA, in south-central California between October 1996 and May 1998.

15. SUBJECT TERMS

raptors; Wind Resource Area; bird fatalities; wind energy development; Tehachapi Pass WRA

\begin{tabular}{|c|c|c|}
\hline \multicolumn{3}{|c|}{ 16. SECURITY CLASSIFICATION OF: } \\
\hline $\begin{array}{l}\text { a. REPORT } \\
\text { Unclassified }\end{array}$ & $\begin{array}{l}\text { b. ABSTRACT } \\
\text { Unclassified }\end{array}$ & $\begin{array}{l}\text { c. THIS PAGE } \\
\text { Unclassified }\end{array}$ \\
\hline
\end{tabular}

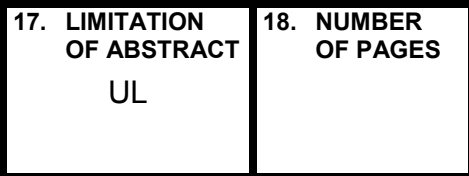

19a. NAME OF RESPONSIBLE PERSON

19b. TELEPONE NUMBER (Include area code) 